
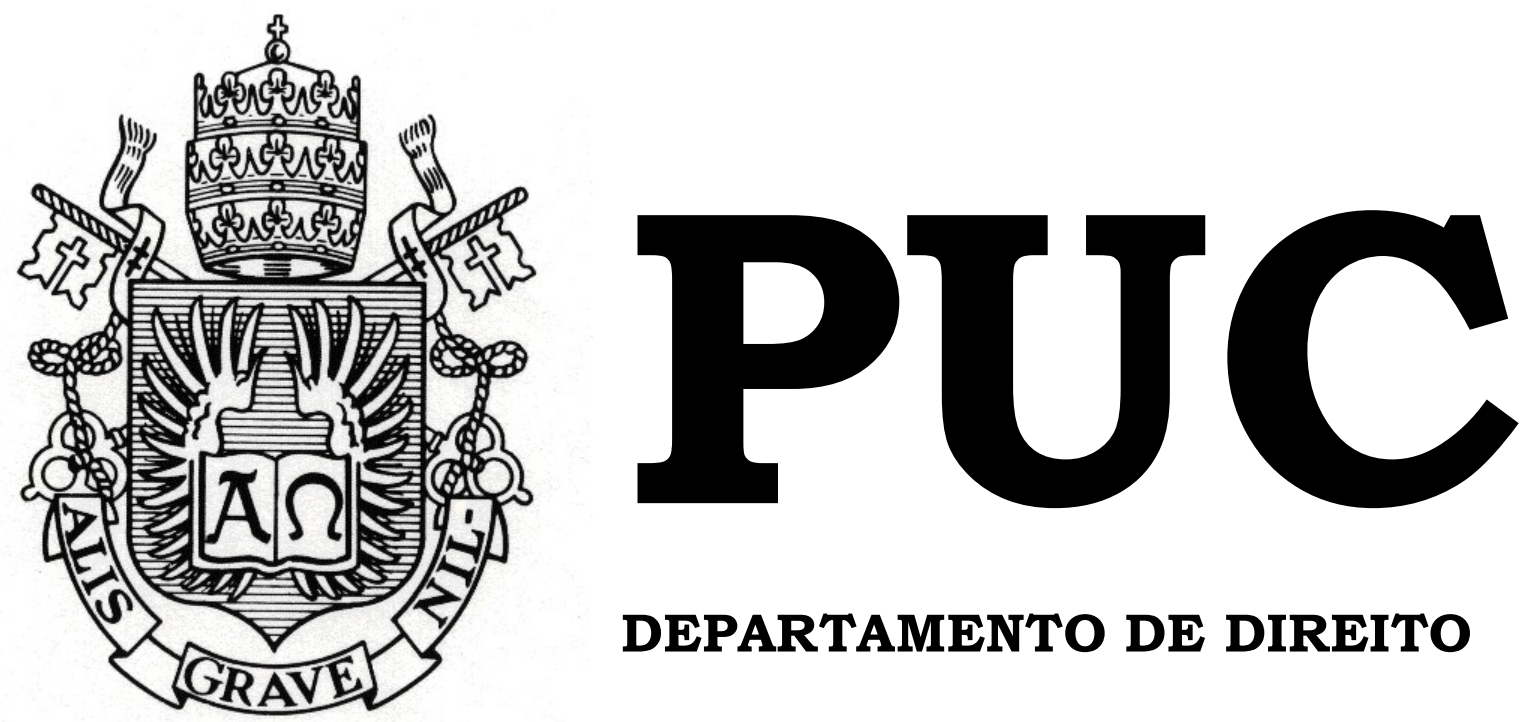

DEPARTAMENTO DE DIREITO

\title{
O MERCADOR DE VENEZA E A FORÇA OBRIGATÓRIA DOS CONTRATOS
}

por

MARIANA DE ATHAYDE FERREIRA

ORIENTADOR: PEDRO MARCOS NUNES BARBOSA 2017.2

PONTIFÍCIA UNIVERSIDADE CATÓLICA DO RIO DE JANEIRO

RUA MARQUÊS DE SÃO VICENTE, 225 - CEP 22453-900

RIO DE JANEIRO - BRASIL 


\title{
O MERCADOR DE VENEZA E A FORÇA OBRIGATÓRIA DOS CONTRATOS
}

\author{
por \\ MARIANA DE ATHAYDE FERREIRA
}

Monografia apresentada ao

Departamento de Direito da Pontifícia Universidade Católica do Rio de Janeiro (PUC-Rio) para a obtenção do Titulo de Bacharel em Direito.

Orientador: Pedro Marcos Nunes Barbosa 


\section{DEDICATÓRIA}

Àqueles capazes de enxergar, no Direito, o leito secreto da arte. 
"Nem tudo que reluz é ouro"

-William Shakespeare "O Mercador de Veneza": Ato II, Cena VI 


\section{RESUMO}

O presente trabalho tem como objetivo a análise da peça shakespeariana "O Mercador de Veneza" à luz das regras do ordenamento jurídico brasileiro e dos princípios da Constituição de 1988, aplicados ao direito contratual. Pretende-se averiguar a extensão da incidência dos princípios pós-modernos (função social do contrato, boa-fé objetiva e equilíbrio econômico) no direito obrigacional contemporâneo, em contraste com os dogmas clássicos da relação obrigacional (relatividade dos efeitos do contrato, obrigatoriedade e "autonomia da vontade"). Para tanto, após realizar-se uma releitura da peça por meio das regras econômicas e patrimoniais do Código Civil de 2002, será feito o exame do caso Shylock vs. Antônio pela perspectiva do Direito Civil Constitucional. Por fim, será apreciado o papel dos juristas e juízes na aplicação direito e em que medida a Literatura pode auxiliar o campo jurídico no que diz respeito às decisões judiciais.

Palavras-chave: William Shakespeare, O Mercador de Veneza, Força Obrigatória dos Contratos, Direito e Literatura. 
INTRODUÇÃO

CAPÍTULO 1 - O MUNDO DE SHAKESPEARE....................................... 12

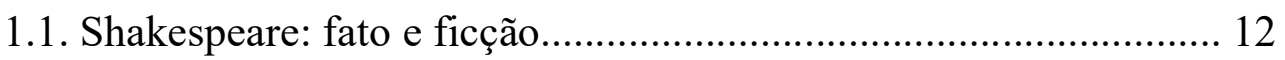

1.2. O menino de Stratford-Upon-Avon................................................. 15

1.3. Dos palcos de Londres à Veneza medieval.................................... 19

CAPÍTULO 2 - O MERCADOR DE VENEZA E O DIREITO.................... 30

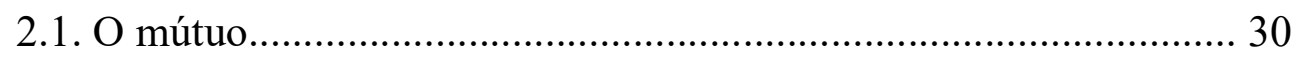

2.2. O julgamento................................................................................ 35

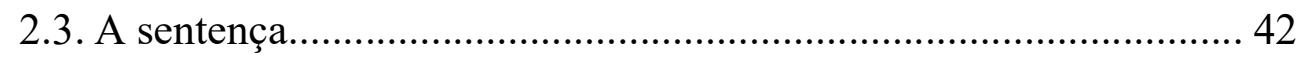

CAPÍTULO 3 - DIREITO, ECONOMIA E PACTA SUNT SERVANDA... 50

3.1. Antônio, Shylock e o direito obrigacional........................................ 50

3.2. Direito das obrigações e mutabilidade............................................. 53

3.3. Liberalismo econômico e vínculo obrigacional............................... 56

3.4. Inadimplemento, indenização e execução forçada........................... 60

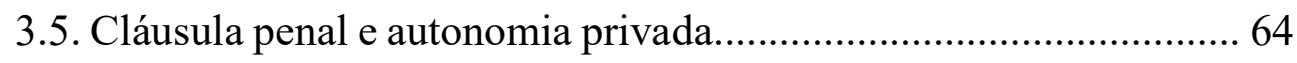

CAPÍTULO 4 - A CORTE DE VENEZA E O DIREITO CIVIL

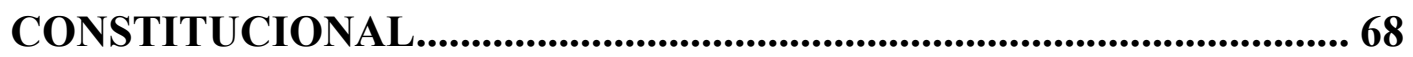

$4.1 \mathrm{O}$ contrato como ferramenta das mudanças sociais............................ 68

4.2 A Constituição de 1988 e o Direito Civil Constitucional................... 74

4.3 O paradigma da essencialidade ...................................................... 78

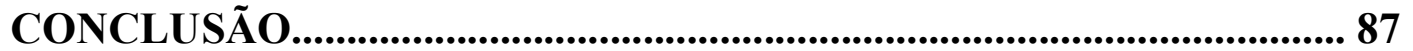

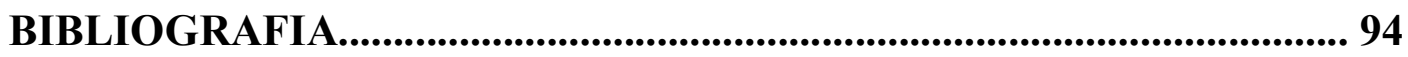




\section{INTRODUÇÃO}

Nem tudo é o que parece ser. ${ }^{1}$ As primeiras impressões enganam e aquilo que de relance se mostra de um jeito, à fundo se revelará de outro. Assim são as pessoas e tudo o que elas tocam. Não podia ser diferente com o Direito e com a Literatura. Esse é o motivo pelo qual a releitura de uma determinada obra literária, assim como a de uma situação jurídica, deve ser ainda mais atenta do que a primeira. ${ }^{2}$ A recriação deve ser tratada de maneira minuciosa, pois é na repetição que se lê nas estrelinhas.

Quando o leitor tem seu primeiro contato com o "Mercador de Veneza", a impressão que se têm é que Shylock é maquiavélico e Antônio, a vítima. Busca-se o bem em oposição ao mal e a luz em oposição às trevas, como num clássico maniqueísmo estereotipado. É comum separar, na rivalidade, o lobo das ovelhas, ainda mais quando o ponto central gira em torno do que seria "certo" ou "errado". No entanto, a busca pelo "preto" e "branco" em relação ao que é justo nem sempre é possível. ${ }^{3}$

\footnotetext{
${ }^{1}$ Em alusão a "All that glitters is not gold". "O Mercador de Veneza": Ato II, Cena VI.

${ }^{2}$ Por isso se mostra importante a releitura dos livros clássicos. Segundo Italo Calvino, "toda releitura de um clássico é uma leitura de descoberta como a primeira." CALVINO, Italo. Por que ler os clássicos. $2^{\mathrm{a}}$ ed. Trad. Nilson Moulin. São Paulo: Companhia das Letras, 2007. p. 11.

${ }^{3} \mathrm{Em}$ especial, essa zona cinzenta entre justiça e injustiça se complica quando falamos em lei, pois desconfia-se dela. Paolo Grossi confere razão a esta desconfiança sentida pelo homem do povo: "se o direito é lei e se lei é somente um comando abstrato com conteúdos indiscutíveis, pensado e desejado ao longínquo Olimpo dos palácios do poder, a sua identificação com um raio que cai sobre a cabeça dos desavisados não é pois tão perigosa". É difícil confiar na lei, pois muitas vezes seu fundamento de validade se baseia em ideias ultrapassadas de mundo e que perduraram tornando a norma um recipiente vazio: "As mitologias, que tiveram um papel fundamental no projeto jurídico burguês, não conseguem se manter em pé diante das necessidades e das solicitações da sociedade contemporânea, extremamente complexa sob os aspectos social, econômico, tecnológico." GROSSI, Paolo. Mitologias jurídicas da modernidade. $2^{\mathrm{a}}$ ed. Trad. Arno Dal Ri Júnior. Florianópolis: Fundação Boiteux, 2007. p. 24-25, 80-81. Isso significa que as mitologias jurídicas produzidas, sobretudo, pelo iluminismo jurídico encontram-se
} 
Nada mais desafiador do que reduzir a definição de justiça a um só conceito. ${ }^{4}$ Melhor será imaginá-la sob a forma de um velho severo e frio, que pesa, que calcula, que mede". ${ }^{5}$ Isso dificulta a busca por uma razão ${ }^{6}$ que permita distinguir a justiça da injustiça. Isso porque a razão se tornou, para o homem, um núcleo da própria natureza humana, um valor que incorpora, segundo Tércio Sampaio Ferraz Júnior, “a própria dignidade humana, não constituindo um meio para obtenção de outros valores, mas o valor que dá sentido aos demais". 7

Para John Rawls, a justiça é "a primeira virtude das instituições sociais"» e ainda assim perdura a dificuldade de definir o que seria justo e injusto, bem como a divergência acerca de um certo julgamento fictício, ocorrido em Veneza, no séc. XIV. ${ }^{9} \mathrm{O}$ caso inclui um contrato de mútuo garantido por fiança, uma libra de carne humana e uma sentença ${ }^{10}$ que agrada alguns juristas famosos e faz

\footnotetext{
defasadas. É preciso reconhecer que a sociedade é dinâmica e que suas leis devem se adaptar a este movimento ativo.

4 "Todos entendem por justiça aquela disposição moral que torna os indivíduos aptos a realizar atos justos e que os faz agir justamente e desejar o que é justo, e analogicamente, por injustiça aquela disposição que leva os indivíduos a agir injustamente e desejar o que é injusto". ARISTÓTELES. Ética a Nicômaco. $2^{a}$ ed. Tradução de Edson Bini. São Paulo: EDIPRO, 2007. p. 145.

${ }^{5}$ Assim é a definição de Chaîm Perelman, que afirma não haver nada menos espontâneo do que a justiça e ainda assim, tem-se dificuldade em conceitua-la. Afirma Chaîm Perelman que "essa expressão escorregadia é dotada de imprecisão conceitual pela própria natureza, na medida que por se adequar ao tempo e ao espaço, só pode carecer de uma conceituação absoluta." PERELMAN, Chaîm. Ética e direito. Tradução de Marian Erantina Galvão G. Pereira. São Paulo: Martins Fontes, 1996. p.46.

6 "Razão é um substantivo cuja origem está no verbo reri, que no significado primitivo queria dizer 'tomar algo por algo', portanto, ligar coisas entre si, donde estabelecer relações e daí calcular, pensar." FERRAZ Jr., Tércio Sampaio. Introdução ao Estudo do Direito: Técnica, decisão, dominação. $6^{\mathrm{a}}$ ed. São Paulo: Atlas, 2012.p. 329.

7 "O problema que se enfrenta é de saber se existe alguma forma de razão, totalizadora e unificadora, que seja para o direito uma espécie de código doador de sentido, um sentido não adaptativo ao próprio direito e que nos permita estimá-lo como legítimo ou ilegítimo.” Ibid. p. 237, 329.

${ }^{8}$ No entanto, desapegar-se das desigualdades histórias, sociais e econômicas é a barreira que impede a adoção de uma postura desinteressada e imparcial e que se chegue a um consenso a respeito da justiça. Essa situação desprovida de interesses ou preconceitos é o que Rawls chama de posição original, justa, onde os contratantes optam pelos princípios de equidade. RAWLS, John. Uma Teoria da Justiça. Tradução de Almiro Pisetta e Lenita M. R. Esteves. $2^{\mathrm{a}}$ ed. São Paulo: Martins Fontes, 2000. p. 3, 13.

${ }^{9} \mathrm{O}$ caso Shylock vs. Antônio repousa sobre um contrato firmado entre dois prósperos comerciantes. Shylock empresta dinheiro a Bassânio e Antônio figura como seu fiador, comprometendo-se a pagar uma libra de sua própria carne do corpo se a dívida não fosse adimplida. Quando o pagamento não é efetuado, o credor cobra a libra de carne, mas o juízo, alegando que não poderia levar outra coisa senão a exata libra de carne (nem mais nem menos e tampouco sangue), impede a sua cobrança.

${ }^{10}$ Ao final, Shylock perde metade de seus bens e é obrigado a se converter ao Cristianismo (Shylock era judeu), evidenciando que, como um Estado cristão, Veneza acreditava ser o cristianismo a única e verdadeira fé, capaz até mesmo de forçar a conversão de alguém que não estava disposto a se converter.
} 
fomentar em outros um grande senso de injustiça. ${ }^{11}$ Ao trazer à tona o julgamento que se passou há quase 500 anos em uma das peças de Shakespeare, esse trabalho não tentará fazer "justiça” ou defini-la. O objetivo será recriar a disputa entre duas personagens shakespearianas, concedendo a ambas uma nova perspectiva da relação contratual sob a ótica do ordenamento brasileiro vigente. O que aconteceria se o contrato firmado entre Shylock e Antônio fosse reproduzido nos dias de hoje ${ }^{12}$

Shylock tinha um contrato feito sob selo ${ }^{13}$, o que significava a dispensa do requisito consideration ${ }^{14}$, bem como da determinação econômica quid pro

Chama-se atenção para o fato de que as conversões ao cristianismo eram mais comuns do que se imagina. Para citar o Papa Inocêncio III, na Bula papal sobre falsos batismos: "Even if torture and intimidation had been employed in receiving the sacrament, one nevertheless does receive the impress of Christianity and may be forced to observe the Christian Faith as one who expressed a conditional willingness though, absolutely speaking, he was unwilling." Tradução livre: Ainda que a tortura e intimidação fossem empregadas para receber o sacramento, receberá a cristandade e será forçado a observar a fé Cristã tal como aquele que demonstra vontade condicional em recebê-la, ainda que, absolutamente falando, esteja indisposto a acolhê-la." POSNER, Richard A.; FRIED, Charles. Shylock on Trial: The Appellate Briefs. Chicago: University of Chicago Press, 2013. p. 3. Pela perspectiva contratual, uma vez que toda a polêmica da trama gira em torno da possibilidade da cobrança da libra de carne em razão da garantia estipulada, o fato de que a questão da condenação de Shylock também toca a seara dos direitos existenciais passa despercebida. Ainda que hoje seja possível a pactuação de contratos com objetos de natureza existencial, a condenação à conversão a outra religião ultrapassaria o limite da disponibilidade dos valores existenciais tanto quanto a retirada de uma libra de carne.

${ }^{11} \mathrm{O}$ juiz que atribuía a Shylock o direito de cortar uma libra de carne do corpo de Antônio reconhecialhe por isso mesmo direito ao sangue, sem o qual não pode na hipótese haver carne. A personagem jurídica vê que não lhe consentem nem uma coisa nem outra, não pode levar senão carne, nenhum sangue, e não pode cortar senão libra à justa, nem mais nem menos. Tenho eu porventura exagerado sustentando que o judeu se vê aqui defraudado no seu direito? Certamente tudo isso se faz no interesse da humanidade, mas a injustiça cometida no interesse da humanidade deixa por isso de ser uma injustiça? E se o fim justifica os meios, porque é que só se reconhece somente depois do julgamento e não antes? JHERING, Rudolf Von. A Luta pelo Direito. 17 a ed. Tradução de João de Vasconselos. Rio de Janeiro: Revista Forense, 1999. p. XIII. Destaque meu.

${ }^{12}$ Foi o que a juíza da Suprema Corte norte-americana, Ruth Bader, e outros quatro juízes procuraram responder ao fazer parte do julgamento simulado que ocorreu em julho de 2016, em Veneza, comemorando o $400^{\circ}$ aniversário da morte de Shakespeare. A recriação do caso foi necessária tendo em vista as diferenças gritantes entre a lei Veneziana do séc. XIV e a Common Law atual. O evento foi

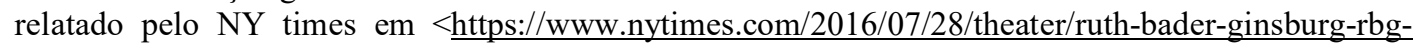
venice-merchant-of-venice.html $>$ acesso em 07 set. 2017.

13 "Go with me to the notary, seal me there". "O Mercador de Veneza": Ato I, Cena III.

${ }^{14}$ Nos dias de Shakespeare, a lei inglesa dos contratos ainda estava nos seus primórdios. Vigorava a teoria da consideration, ao invés da teoria da causa da Lei Romana dos contratos. Enquanto esta investigava a intenção das partes na hora da realização do contrato, aquela validava ou não o pacto dependendo da existência de reciprocidade econômica das prestações, exigindo uma determinação econômica quid pro quo. O requisito de consideration era desnecessário somente para os contratos feitos sob selo. Os instrumentos legais feitos sob selo tinham significância especial e eram tratados de maneira diferente. Era o caso de Shylock. Segundo Brian H. Bix, somente ao final do século XVII a visão acerca 
$q u o^{15}$. Além disso, uma das peculiaridades da Common Law no que tange o empréstimo de dinheiro, na época de Shakespeare, era a obrigatoriedade das penalidades acessórias. Isso quer dizer que, nas Cortes da Common Law ${ }^{16}$, o devedor inadimplente não se veria livre da multa pelo inadimplemento se oferecesse o pagamento da quantia principal no dia seguinte ao término do prazo. ${ }^{17} \mathrm{O}$ credor tinha o direito de insistir na multa, recusando o pagamento original. ${ }^{18}$ De fato, a Common Law não poderia ajudar Antônio. Foi por isso que Pórcia, disfarçada de advogado e centrada em salvar Antônio, inicia seu discurso fazendo uso da equidade e misericórdia, adotando atitude semelhante à Corte de Chancelaria. Equidade, no entanto, não é misericórdia. ${ }^{19}$

do requisito consideration mudou. Afastou-se a ideia de que uma reciprocidade razoável seria necessária para que a promessa pudesse ser cobrada. BIX, Brian H. Contract Law: Rules, Theory, and Context. Nova Iorque: Cambridge University Press, 2012. p. 33.

${ }^{15}$ A expressão latina significa "tomar uma coisa por outra" e foi eternizada pelo filme "O silêncio dos inocentes" de 1991, quando o assassino Hannibal Lecter aceita ajudar a detetive Clarice em troca de informações pessoais desta: "Quid pro quo, Clarice". Keeton dá um exemplo prático em seu livro: se "A" prometesse dar 5000 libras ao filho em nome de seu amor e consideração, a lei romana permitiria, mas a lei inglesa não, pois amor e consideração não são considerações legais válidas, sendo incapazes de determinação econômica. KEETON, George Williams. Shakespeare and his legal problems. London: A \& C. Black, 1930. p. 13.

16 Para uma breve explicação do sistema judiciário da época, Flávia Lages de Castro explica que o direito inglês é obra das Cortes Reais (Cortes de Common Law) e das Cortes de Equity. "A Common Law nasce como a lei comum a todos os ingleses, em oposição aos direitos locais feudais. Seu aparecimento, a partir do séc. XIII, será obra exclusiva dos tribunais de justiça, também conhecidos pelo nome do local onde inicialmente se estabelecem, Tribunais de Westminster. Já o Equity nasceu da necessidade criada pela própria limitação da Common Law, quando, após um período de grande desenvolvimento, se estagnou, não totalmente, mas a ponto de não conseguir suprir a questão mais cara para a Justiça Inglesa, a questão da razoabilidade" CASTRO, Flávia Lages de. História do Direito: Geral e Brasil. $8^{\mathrm{a}}$ ed. Rio de Janeiro: Lumen Juris, 2011. p. 195 - 196.

17 "One peculiarity of the common money bond in Shakespeare's days was that the penalty was fully enforceable by law” KEETON, George Williams. Op. cit., p. 13.

${ }^{18}$ Sendo assim, Shylock tinha um direito inquestionável a libra de carne e a audiência de Shakespeare sabia disso. Ainda que mais tarde na Inglaterra pudesse se falar em ilegalidade contra políticas pública, esse princípio não existia à época. A Corte não poderia olhar por cima do selo do contrato para examinar as intenções das partes. O primeiro caso de ilegalidade do objeto que levou a invalidação do contrato sob selo somente ocorreria em 1766, longe de poder ser alegado por Antônio, pois somente a partir do caso Collins vs. Blantern a ilegalidade do objeto do contrato poderia ser pleiteada para invalidar um contrato feito sob selo. Ibid. p. 17.

${ }^{19} \mathrm{Na}$ época de Shakespeare, lei e equidade não eram administradas nas mesmas cortes, mas a Corte de Chancelaria já interferira em cobranças absurdas para prevenir os abusos de credores. Segundo Keeton, "equity is a higher conception of justice itself, than is to be found in the common law". Ibid. p. 14, 19. Tradução livre: Equidade é uma concepção mais elevada da própria justiça do que aquela que poderia ser encontrada na Common Law. Em Aristóteles, encontra-se a concepção de equidade semelhante à de justiça, mas também distinta. Aquela é justa não de acordo com a lei e sim conforme um corretivo de justiça legal. A justiça, portanto, pode se referir a algo legal ou algo equitativo: "a equidade, embora 
O único argumento legal que poderia ter salvado Antônio naquela época era a alegação de falsidade na interpretação da cláusula penal ${ }^{20}$, uma vez que quando Shylock sugeriu a libra de carne em garantia, disse que se tratava de uma brincadeira $^{21}$, ou, nas palavras do próprio Shylock, "a merry sport". 22 Antônio sequer trouxe esse aspecto do contrato à tona na hora do julgamento, sendo este desconhecido pela Corte. ${ }^{23}$

A recriação do julgamento em "O Mercador de Veneza" será também o objetivo deste trabalho, colocando o caso sob a luz do atual ordenamento jurídico brasileiro. No primeiro capítulo será feita uma introdução crucial ao momento histórico de Shakespeare. ${ }^{24}$ Nesta mesma linha, o capítulo segundo esmiuçará a narrativa textual da obra, ressaltando os aspectos jurídicos. No terceiro capítulo, terá início a reconstrução do julgamento sob uma perspectiva

superior a uma espécie de justiça, é, ela mesma, justa: não é superior à justiça ao ser genericamente distinta dela. Justiça e equidade são, portanto, a mesma coisa, sendo ambas boas, ainda que a equidade seja a melhor". ARISTÓTELES. Op. cit., p. 172.

${ }^{20}$ KEETON, George Williams. Op. cit., p. 12.

21 Ainda que Antônio não se recordasse deste aspecto, Bassânio, o verdadeiro devedor do contrato principal, estava presente na hora da pactuação da cláusula penal e, ao invés de pedir clemência perante o Tribunal, poderia suscitar este detalhe de suma importância.

22 "Go with me to the notary, seal me there; Your single bond and, in a merry sport; If you repay me not in such day; In such place, such a sum or sums as are; Express-d in the condition, let the forfeit; Be nominated for a equal pound; Of your fair flesh." "O Mercador de Veneza": Ato I, Cena III.

${ }^{23}$ Esse detalhe é tão importante que foi nele baseada a decisão tomada no julgamento simulado em 2016. A juíza inglesa que precedeu o julgamento, Ruth Bader, disse que se tratava de uma brincadeira e que nenhuma Corte apoiaria isto: "We agreed it was a merry sport, and no court would enforce it". A decisão ainda contava com a obrigação de pagar a Shylock três mil ducados e tornar nula a cláusula que estipulava a garantia. Quanto à Pórcia, esposa de Bassânio, disfarçada de advogado para ajudar Antônio, foi "condenada" por ser uma impostora. Deveria frequentar a universidade de direito na Universidade de Pádua, onde um dos juízes, Laura Picchio Forlati lecionava. $<$ https://www.nytimes.com/2016/07/28/theater/ruth-bader-ginsburg-rbg-venice-merchant-ofvenice.html $>$ acesso em 07 set. 2017. À luz do ordenamento brasileiro, é possível que Pórcia fosse condenada por falsidade ideológica: Segundo o art. 299 do Código Penal, o crime consiste em "Omitir, em documento público ou particular, declaração que dele devia constar, ou nele inserir ou fazer inserir declaração falsa ou diversa da que devia ser escrita, com o fim de prejudicar direito, criar obrigação ou alterar a verdade sobre fato juridicamente relevante". É o caso de Pórcia, que falsificou propositalmente a carta endereçada ao Doge de Veneza para que lhe fosse permitido advogar. Dessa forma, fica preenchido o requisito que caracteriza a falsidade ideológica, qual seja, a capacidade de iludir a autoridade a que se destina o documento adulterado.

${ }^{24}$ Explorar a trajetória do dramaturgo em meio ao período Elisabetano é essencial para situar o contexto no qual a peça em questão foi redigida. Não se trata somente de uma biografia para conhecer a fundo o autor, mas também desvendar os motivos por trás da criação da peça, em especial àqueles oriundos das experiencias do Bardo com a Common Law. 
econômica. ${ }^{25}$

No quarto capítulo, ocorrerá a segunda parte do julgamento simulado, por meio da contraposição dos princípios pós-modernos com os dogmas clássicos (obrigatoriedade do contrato, relatividade dos efeitos e autonomia da vontade). Assim, será possível analisar os impactos da Constituição de 1988 no Direito Obrigacional, principalmente no que diz respeito aos contratos. $\mathrm{O}$ objetivo, ao final, é verificar se Shylock seria vitorioso em alguma das simulações nos dias de hoje. ${ }^{26}$ Em especial, procura-se analisar se os princípios pós-modernos da relação contratual seriam imprescindíveis para a vitória de Antônio, ou se seria possível evitar de outro modo a cobrança de uma libra de carne como garantia.

\footnotetext{
${ }^{25}$ Primeiro, a questão do contrato será analisada à luz das regras do direito civil, sob uma perspectiva puramente econômica, sem levar em consideração os princípios pós-modernos do direito contratual (função social, equilíbrio econômico e boa-fé objetiva). Assim, será possível descobrir se o ordenamento seria capaz de impedir a retirada da libra de carne, mitigando a obrigatoriedade contratual, contudo sem utilizar os argumentos de cunho social que ganharam destaque a partir da Constituição de 1988.

${ }^{26}$ Também será possível responder as perguntas de Italo Calvino: "Por que ler os clássicos em vez de concentrar-nos em leituras que nos façam entender mais a fundo o nosso tempo?" e "Onde encontrar o tempo e a comodidade da mente para ler clássicos, esmagados que somos pela avalanche de papel impresso da atualidade? "CALVINO, Italo. Por que ler os clássicos. $2^{a}$ ed. Trad. Nilson Moulin. São Paulo: Companhia das Letras, 2007. p. 14.
} 


\section{CAPÍTULO 1 - O MUNDO DE SHAKESPEARE}

\subsection{Shakespeare: fato e ficção}

"Sabe-se muito" sobre Shakespeare e ao mesmo tempo não se sabe nada. Um retrato escuro e oval, com $55 \mathrm{~cm}$ de altura e $18 \mathrm{~cm}$ de largura, pode conter a única imagem do dramaturgo documentada enquanto ele ainda era vivo: Um homem nos quarenta anos, praticamente calvo, mas de boa aparência, barba aparada, um brinco na orelha esquerda, expressão confiante e sensualidade natural. ${ }^{27}$ Pode ser Shakespeare e pode também não ser, pois as outras imagens que se tem do Bardo $^{28}$ foram ambas feitas após sua morte. Duas delas são as mais confiáveis: uma gravura ${ }^{29}$ no Primeiro Portfólio e um busto ${ }^{30}$ na igreja da Santíssima Trindade, em Stantford-upon-Avon, onde nasceu e foi enterrado. A aparência é, portanto, um mistério, assim como o próprio dramaturgo.

Não há quantidade suficiente de documentos que permita conhecer a fundo a vida do Bardo, apesar de se afirmar que a quantidade é significante para

\footnotetext{
${ }^{27}$ A pintura foi doada em 1856 para a National Portrait Gallery, em Londres e, segundo Bill Bryson, o que se vê "não é um homem que mereça total confiança para acompanhar uma esposa ou uma filha crescida”. BRYSON, Bill. Shakespeare: O mundo é um palco. Tradução de José Rubens Siqueira. Companhia das letras: São Paulo, 2008. p 10.

${ }^{28}$ Um bardo, na Europa antiga, era o nome dado àquele encarregado de transmitir histórias, mitos, lendas e poemas de forma oral, cantando as histórias do seu povo em poemas recitados. Shakespeare é chamado frequentemente de poeta nacional da Inglaterra, "Bardo do Avon" ou simplesmente "The Bard" ("O Bardo").

${ }^{29}$ Feita por Martin Droeshout em 1623, a gravura é usada para apresentar a primeira coletânea das peças de Shakespeare. Mais informações sobre o primeiro portfólio em $<$ https://www.bl.uk/collectionitems/shakespeares-first-folio > acesso em 08 out. 2017.

${ }^{30}$ Executado pelo artesão Gheerart Janssen e instalado em 1623, já não é o mesmo que foi quando inaugurado, pois as cores foram renovadas e depois caiado, para retornar ao estado original. Mais

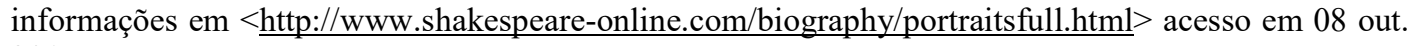
2017.
} 
um dramaturgo daquela época. ${ }^{31}$ Para Bárbara Heliodora, de todos os mitos a respeito de Shakespeare, é possível que o mais danoso seja o que afirma que tudo o quanto se sabe da vida do poeta poderia caber escrito em um selo. ${ }^{32}$ Pouco do que se sabe é fato e muito é especulação. Tem razão Bill Bryson quando diz que toda biografia de Shakespeare é 5\% fato e 95\% conjetura. ${ }^{33}$ Estudar Shakespeare muitas vezes significa se render à ficção e é isso que torna a sua história tão misteriosa e interessante. Para aqueles que se debruçam sobre Shakespeare a procura de entretenimento, a satisfação é completa, mas quando é preciso compreender o homem por trás das obras, o desafio é árduo.

Com a falta de documentos surgem dúvidas até sobre a verdadeira identidade de Shakespeare e existe a pergunta se era, na verdade, um pseudônimo por trás do qual se escondiam vários autores. É espantoso pensar que um só homem poderia ter produzido tantas obras geniais com um dom incomparável. O assombro causado pena genialidade não pode ser, contudo, confundido com uma conspiração tão excepcional capaz enganar a todos até 400 anos depois da morte do dramaturgo. ${ }^{34}$ Deste modo, a atitude mais racional é

\footnotetext{
31 "A documentação sobre William Shakespeare é exatamente aquela que se pode esperar de uma pessoa em sua posição naquele tempo. Parece escassa só porque nosso interesse nele é tão intenso. Na verdade, sabe-se mais sobre Shakespeare do que sobre quase todos os outros dramaturgos de sua época." BRYSON, Bill. Op. cit., p. 24.

32 "Ao contrário, a vida de Shakespeare é excepcionalmente bem documentada para um elisabetano sem ligações com a nobreza ou com a carreira política. Somam mais de cem documentos legais, comerciais e profissionais e referencias escritas" HELIODORA, Bárbara. A comédia dos erros e O Mercador de Veneza. Rio de Janeiro: Nova Fronteira,1990. p. 9.

${ }^{33}$ BRYSON, Bill. Op. cit., p. 22.

${ }^{34}$ Segundo Cristiane Busato Smith, os nomes mais absurdos da lista de autores que seriam na verdade Shakespeare vão desde a rainha Elisabeth I até o escritor Daniel Defoe. Mais recentemente, as hipóteses mais comuns seriam Francis Bacon, Christopher Marlowe, o conde de Oxford e o conde de Essex. SMITH, Busato Cristine. A vida de William Shakespeare. In: Shakespeare, sua época e sua obra. LEÃO, Liana de Camargo; SANTOS, Marlene Soares dos Santos. Curitiba: Beatrice, 2008. p. 21. Segundo Bill Bryson, a teoria baconiana foi a que mais ganhou asas no mundo, sendo seguida também por Mark Twain e Henry James. Muitos se convenceram de que códigos secretos se escondiam nas peças, revelando a sua verdadeira autoria. $\mathrm{O}$ culto baconiano era tamanho que Edwin Durning-Lawrence publicou um livro em 1910 revelando anagramas contidos nas obras. O mais famoso deles é uma palavra inventada em "Trabalhos de amor perdidos", "honorificabilitudinitatibus", que poderia ser transformada no hexâmetro latino: "H iludi F. Baconis nati tuiti orbi" ou, na tradução de Bryson: "Estas peças, produtos de F. Bacon, são preservadas para o mundo". BRYSON, Bill. Op. cit., p. 183. Até os dias de hoje, este é um assunto que dá margem a diversas interpretações. Mais informações sobre as controvérsias atuais na página on-line da revista Veja: <http://veja.abril.com.br/blog/o-leitor/sera-queshakespeare-existiu-de-verdade/> acesso em 25 out. 2017.
} 
afirmar que o Bardo existiu como um só homem e assim, pode-se falar sobre William Shakespeare.

As dúvidas aceitáveis são aquelas ligadas à cronologia e verdadeira quantidade das peças, que também surge da falta de dados concretos. Nem mesmo tem-se certeza da sua grafia, pois somente se conhece seis assinaturas feitas por ele e o nome nunca é escrito da mesma maneira: Willm Shaksp", "William Shakespere", "Wm Shakespe", "William Shakspere", "Willm Shakspere" e "William Shakspeare". ${ }^{35}$ Tampouco é possível afirmar a pronúncia correta, não sendo impossível que a forma mundialmente conhecida esteja equivocada.

Para este capítulo, interessa pouco a imaginação e a polêmica, por mais sedutoras que o sejam. Ainda que os mitos sobre Shakespeare sejam muitos e que seja natural sentir-se atraído por eles, tentar-se-á deter-se aos aspectos fáticos e, sobretudo, os legais, dos quais se tenha registro. Não há caminho melhor para compreender o envolvimento do Direito e da Literatura nas peças de Shakespeare do que conhecer a origem da afinidade do dramaturgo com o mundo jurídico, construída ao longo de sua vida. $\mathrm{O}$ objetivo é resgatar os aspectos fáticos da vida de William Shakespeare, situar o momento histórico e, mais importante, investigar a relação do Bardo com a lei.

Assim, será possível criar uma conexão lógica e legal entre o dramaturgo e suas peças, principalmente "O Mercador de Veneza”. A questão gira em torno das experiências do próprio Bardo com a Inglaterra do séc. XVI e XVII ${ }^{36}$, em

\footnotetext{
${ }^{35}$ BRYSON, Bill. Op. cit., p. 16.

${ }^{36}$ Shakespeare foi um marco no Renascentismo literário da Inglaterra durante a Idade Moderna, período que se considera desde 29 de maio de 1453 quando ocorreu a tomada de Constantinopla pelos turcos otomanos até a Revolução Francesa, em 14 de julho de 1789. A época moderna pode ser considerada, exatamente, como uma época de "revolução social", com o início do modo de produção capitalista e o aumento exorbitante do comércio. Para a Literatura, importa especialmente a impressão da bíblia em 1450, que deu origem ao surgimento de muitos livros, com a aparição de escritores por toda a Europa, dando força ao movimento literário. Na Itália havia Maquiavel (1469 - 1527), na Espanha, Cervantes (1547 - 1616), em Portugal Luís de Camões (1524 - 1580). Ao mesmo tempo ocorria o Romantismo artístico, com Leonardo da Vinci (1452 - 1519) e Michaelangelo (1475 - 1564). No Renascentismo científico tinha-se Isaac Newton (1642 - 1727) na Inglaterra, Galilei Galilei (1564 - 1642) na Itália e Descartes (1595 - 1650) na França. Segundo Paulo Miceli, a ideia constantemente associada ao
} 
especial as vivências relacionadas às questões legais, ${ }^{37}$ que possivelmente influenciaram a significativa quantidade de julgamentos e juristas nas suas obras.

\subsection{O menino de Stratford-Upon-Avon}

Sabe-se que nasceu no ano de 1564, em Stratford-upon-Avon, uma cidade de importância considerável para a época e cerca de $140 \mathrm{~km}$ de distância de Londres. Especula-se que tenha nascido no dia 23 de abril, mas essa informação não é clara, pois o único fato concreto que se tem é o dia do batizado: 26 de abril. ${ }^{38}$ Era uma época peculiar para se nascer. Um ano antes, um surto de peste dizimara 1/3 da população de Londres e ao longo dos anos de 1560 a comida era escassa. ${ }^{39}$

\footnotetext{
Renascimento é a de que foi um período de (re)vivificação dos valores da cultura greco-latina. Diante dos antigos - os gigantes -, os letrados do Renascimento seriam uma espécie de anões, apesar de lhes ser facultada a possibilidade de escalar os ombros dos antecessores para enxergar mais longe. Segundo Miceli, o humanista espanhol Jual Luis Vives (1492-1540) condenava essa classificação, afirmando que os homens de seu tempo não eram anões assim como os antigos não eram gigantes. Eram homens do século XVI que seriam mais cultos graças aos antigos. O Renascimento não colocava em confronto o moderno e o antigo e sim os conciliava em suas formas de progresso: $\mathrm{O}$ circular, que celebrava o antigo (eterno entorno) e o linear, que desviava da Antiguidade. MICELI, Paulo. História Moderna. São Paulo: Contexto, 2016. p. $30-31$.

${ }^{37}$ Em relação ao direito, a Era Moderna possui importância significativa. Presenciou-se o advento de uma nova realidade normativa, com o desenvolvimento interno do sistema da ciência jurídica que, segundo António Manuel Hespanha, provocou uma "grave crise no seio do pensamento jurídico europeu". HESPANHA. António Manuel. História das Instituições: Épocas medieval e moderna. Coimbra: Almedina, 1982. p. 479. Sobretudo, a nova fase de construção sistemática do direito da Era Moderna se fundamentava na remodelação do instrumental lógico-conceitual a fim de simplificar a ciência jurídica. Afastou-se da complicada dialética aristotélico-escolástica, aproximando-se a uma dialética jurídica simplificada, natural, próxima do senso comum. Ibid. p. 483.

${ }^{38}$ Muitas paróquias não obedeciam a regra de registrar o nascimento e Stratford só começou a realizar registros em 1558. Há ainda um problema em relação à data de 23 de abril, pois faz referência ao calendário juliano. O calendário gregoriano só foi criado em 1582, quando Shakespeare era adulto. O que seria o dia 23 de abril naquela época, seria então hoje 3 de maio. BRYSON, Bill. Op. cit., p. 31.

${ }^{39}$ A população de Londres havia diminuído consideravelmente devido à peste que se instalara 300 anos antes. A década anterior ao nascimento de Shakespeare sofreu uma queda de população de cerca de 6\%. Londres era também o local de desembarque dos navios viajantes, o que sempre renovava o estoque de doenças contagiosas, o que levou a quantidade de mortes a ultrapassar as de nascimento durante dois séculos. Ibid. p. 28, 31 .
} 
Cinco anos antes do seu nascimento, Elizabeth I foi coroada. Era um período no qual o monarca exercia seus poderes de forma plena. A rainha estava no alto da pirâmide social e as restrições legais se impunham sobre todos os aspectos. A desordem era um problema, mas Elizabeth I conseguiu se impor progressivamente sobre a nação e lidar com os conflitos religiosos. ${ }^{40}$ Ainda que fosse tempo de agitação, a transição para o protestantismo se deu de forma razoavelmente tranquila, sem guerras civis em larga escala. ${ }^{41} \mathrm{O}$ interesse da Coroa não era dirigir as crenças religiosas, e sim garantir a fidelidade do povo. ${ }^{42}$

A principal preocupação do reinado elisabetano era evitar perturbações na vida civil e conflitos externos. A monarca fazia uso das leis suntuárias, que se propunham contornar a falta de ordem e, até 1604, estabeleciam as mais diversas regras de conduta. ${ }^{43}$ Havia leis sobre vestimenta, para determinar o que cada um poderia vestir, dependendo de quanto a pessoa ganhava por ano. ${ }^{44} \mathrm{~A}$ alimentação recebia regras igualmente aleatórias, restringindo-se a quantidade de pratos por refeição. ${ }^{45}$

As restrições com a conduta pública eram severas e variavam desde

\footnotetext{
40 "Apesar de uma revolta dos nobres do Norte em 1569, que procurou destronar a rainha e restaurar o catolicismo, o fato é que a história começou a mudar em favor dos ingleses". BARROSO, Luís Roberto. Shakespeare e seu tempo. In: ALQUÉRES, José Luiz; NEVES, José Roberto de Castro (Org.). Ele, Shakespeare, visto por nós, os advogados. Rio de Janeiro: Janeiro, 2017.p. 36.

${ }^{41}$ BRYSON, Bill. Op. cit., p. 32

${ }^{42}$ Quanto a Shakespeare, é difícil dizer até que ponto era religioso, apesar das inúmeras referências religiosas em seus trabalhos. "A história de Caim aparece 25 vezes nas 38 peças - uma proporção bastante alta. Mas Otto Jespersen e Caroline Spurgeon consideram Shakespeare quase inteiramente desinteressado de temas bíblicos". Ibid. p. 65.

${ }^{43}$ Segundo Pierre Bourdieu, o direito é um dos sistemas capazes de, como a arte e a religião, impor o poder simbólico, uma vez que é a forma, por excelência, do discurso capaz de produzir efeitos por sua própria força. Sobretudo, no direito, o poder simbólico se dá através da codificação que "introduz nas relações sociais uma nitidez, uma previsibilidade e, por este modo, uma racionalidade que nunca é completamente garantida por princípios práticos ou habitus ou pelas sanções do costume." Como instrumento de regulação, a lei cumpre sua função política de instrumento de imposição ou legitimação da dominação de uma classe sobre outra (violência simbólica). BOURDIEU, Pierre. O Poder Simbólico. $7^{\mathrm{a}}$ ed. Tradução de Fernando Tomaz. Rio de Janeiro: Bertrand Brasil, 2004. p. 11, 237, 249.

${ }^{44}$ Por exemplo, Bill Bryson explica que uma pessoa que ganhasse vinte libras por ano, poderia portar gibão de cetim, mas não vestido de cetim. Para usar o cetim de maneira irrestrita era preciso ganhar cem libras por ano. Ainda assim, não poderia usar veludo carmesim nem azul, pois eram as cores dos Cavaleiros da Liga e seus superiores. Meias de seda somente eram permitidas a cavaleiros e seus filhos, funcionários e atendentes reais. BRYSON, Bill. Op. cit., p. 36.

${ }^{45}$ Segundo Bryson, um cardeal poderia comer nove pratos por refeição e quem ganhava menos de 40 libras ao ano (a grande maioria) tinha permissão para apenas dois pratos mais a sopa. Ibid. p. 37.
} 
multas por receber um hóspede sem permissão de um funcionário da justiça ou casar sem a benção do monarca, até punir os donos de patos que andassem na rua, por apropriação indébita ${ }^{46}$ de cascalho urbano ${ }^{47}$. À primeira vista, é de se pensar que essas regras mal fossem aplicadas, mas isso não é verdade, por mais esdrúxulas que aparentem ser nos tempos contemporâneos. Doze anos antes do nascimento de William Shakespeare, por exemplo, seu pai, John Shakespeare, fora multado em um xelim por manter um monte de esterco na rua (era uma multa relativamente alta, provavelmente dois dias de salário para John). ${ }^{48}$

Há também registros de 1570, quando William já era vivo, de que seu pai fora processado por comercializar lã ${ }^{49}$ e emprestar dinheiro cobrando juros além da taxa legal, ambas atividades ilegais. ${ }^{50}$ As multas por usura, principalmente, eram severas, por ser considerada uma prática detestável. ${ }^{51}$ No entanto, não foram só problemas que as regras legais trouxeram para Shakespeare. Aos cinco anos, ele já tinha contato com outros dramaturgos, pois seu pai, John, era prefeito e quando as companhias teatrais chegavam em uma cidade, a lei determinava que deviam ir à casa do prefeito para apresentar cartas de recomendação. Assim, recebiam a autorização para apresentar os espetáculos. ${ }^{52}$ Em 1576, John

\footnotetext{
${ }^{46}$ O Código Penal brasileiro classifica a apropriação indébita: art. 168 "Apropriar-se de coisa alheia móvel, de que tem a posse ou a detenção".

${ }^{47}$ BRYSON, Bill. Op. cit., p. 37.

${ }^{48}$ Ibid. p. 37

${ }^{49}$ Ibid. p. 40.

${ }^{50}$ Era um tempo no qual não haviam bancos ou instituições de crédito que fornecessem empréstimos como nos dias de hoje, por isso era comum que isso ocorresse entre as próprias pessoas. É nessa mesma situação que se encontram as personagens em "O Mercador de Veneza", em uma época na qual a prática dos judeus em emprestar dinheiro era, ao contrário do que se pensa, muito bem-vinda, tendo em vista a inexistência de empréstimos bancários.

${ }^{51}$ Talvez, por tomar posterior conhecimento destes fatos, Shakespeare demonstre certa compaixão por Shylock, em "O Mercador de Veneza", quando é insultado pelos cristãos, incluindo Antônio, que abominam a prática. No Ato I, Cena III, Shylock diz: "Signor Antônio, quantas, quantas vezes lá no Rialto fizestes pouco caso do meu dinheiro e de eu viver de juros!”. Shylock cita os feitos de Jacó que, quando pactuou com seu tio, ficou com os cordeiros que nasceram do cruzamento das ovelhas, como se juros fossem, como forma de justificar a prática do mesmo com a moeda. Antônio abomina a comparação na memorável frase "O diabo sabe citar a escritura quando lhe convém".

52“Apresentavam suas cartas de recomendação, lacradas com sinete, para provar que não eram vagabundos e tinham um patrono poderoso a protege-los" GREENBLATT, Stephen. Como Shakespeare se tornou Shakespeare. Tradução de Donaldson M. Garschagen; Renata Guerra. São Paulo: Companhia das Letras, 2011. p. 25.
} 
abandonou o posto público e fez parte da lista de moradores de Stratford que se pensara terem deixado de comparecer à igreja por medo de processos e dívidas. ${ }^{53}$ Nesta época, Shakespeare já tinha doze anos.

Quando tinha idade suficiente para ir à escola, William recebeu uma boa educação na King's New School. Apesar de não haverem documentos suficientes que comprovem isso, é onde todos os garotos que ali moravam iam estudar. Ainda que não haja registros nesse sentido, pois todos sumiram, teria sido estranho se Shakespeare não tivesse frequentado essa escola. ${ }^{54}$ Era uma instituição estrita e que aplicava castigos físicos, e que também se dedicava à educação clássica, com o aprendizado do latim. ${ }^{55}$ A grade curricular não costumava contar com história ou literatura inglesa, tampouco biologia, química, economia ou sociologia. Havia, sim, noções de aritmética. ${ }^{56} \mathrm{O}$ método de ensino era por memorização e repetição, com análise de textos elaborados, exercícios de imitação ${ }^{57}$ e variação retórica. ${ }^{58}$

Foi assim o início do apetite do Bardo pela linguagem, que incentivado pela escola ao estimular os alunos a representar peças antigas, tornou-se apaixonado pelas comédias e tragédias clássicas. Em especial, se interessava pela combinação teatral da lógica e da confusão. ${ }^{59}$ Além de despertar os talentos naturais de William, a escola o preparou bem e alimentou atributos que hoje são

\footnotetext{
${ }^{53}$ BRYSON, Bill. Op., cit., p. 41.

54 "We don't have any records showing that Shakespeare attended the local grammar school - they are missing for that period - but it would be odd if he hadn't'. MCGUIRE, Laurie; SMITH, Emma. 30 Great Myths About Shakespeare. Chichester: John Wiley \& Sons, 2013. p. 12. Tradução Livre: Não temos registros de que Shakespeare frequentou a escola local, pois estão desaparecidos para este período, mas seria estranho que ele não a tivesse frequentado.

${ }^{55}$ Stephen Greenblatt brinca, ou não, que "todos aceitavam que o ensino do latim fosse inseparável das surras" e que "talvez as nádegas tenham sido criadas para facilitar a aprendizagem". GRENNBALT, Stephen. Op. cit., p. 22.

${ }^{56}$ As escolas chamadas de Grammar Schools eram assim chamadas porque ensinavam gramática e a gramática ensinada era o latim. MCGUIRE, Laurie; SMITH, Emma. Op. cit., p. 12.

${ }^{57}$ Imitatio significa tentar reproduzir o estilo de um autor renomado. Ibid. p. 13.

${ }^{58}$ Copia significa falar a mesma coisa de diversas maneiras. Ibid. p. 13.

${ }^{59}$ Sobretudo os alunos encenavam peças de Plauto e Terêncio. "Uma vez, em Londres, quando era um jovem dramaturgo à procura de tema para uma comédia, ele simplesmente pegou 'Os Menecmos', acrescentou um segundo par de gêmeos para duplicar a confusão e escreveu 'A comédia de erros'. A peça fez grande sucesso" GRENNBALT, Stephen. Op. cit., p. 24.
} 
valorizados em suas obras, como a paixão pela linguagem e a variação estilística. A educação formal teve aí seu fim, quando William tinha 15 anos, sem que o Bardo tenha frequentado a universidade. ${ }^{60}$

Casou-se com 18 anos com Anne Hathawhay, sendo relativamente precoce em comparação aos jovens daquela época, que se casavam entre 25 e 30 anos. ${ }^{61}$ Teve três filhos (Susanna e os gêmeos Judith e Hamnet) dos quais logo se afastaria para perseguir a carreira de dramaturgo em Londres. ${ }^{62}$ Ainda que período entre 1585 e $1952^{63}$ seja vazio em todas as biografias do Bardo, uma vez ausente documentos que deixam qualquer pista definitiva e confiável do seu paradeiro, supõe-se que chegou a Londres no final da década de 1580, indo morar longe da família.

\subsection{Dos palcos de Londres à Veneza medieval}

Shakespeare viveu em um período de transformação da Inglaterra, que saía do patamar de país periférico para ser uma das grandes potencias internacionais. Ainda que hoje se enxergue Shakespeare como um dos melhores dramaturgos de todos os tempos, não era glamorosa a vida do teatro em Londres. Os teatros, bordéis, prisões, lojas de pólvora, cemitérios não consagrados e hospícios recebiam tratamento semelhante, obrigados a se situarem fora das

\footnotetext{
${ }^{60}$ BRYSON, Bill. Op., cit., p. 44.

${ }^{61}$ Por que tão cedo? A resposta viria meses depois, com o nascimento da primeira filha, Susanna. "O que torna o fato ligeiramente intrigante é que não era nada raro uma noiva estar grávida no dia do casamento - 40\% das noivas encontravam-se neste estado”. Ibid. p. 45 - 46.

${ }^{62}$ Apesar de morar longe da família, Shakespeare nunca deixou de fazer investimentos na cidade. Em 1605, por exemplo, investiu alta quantia em dízimos na cidade de Stratford. Anos antes, em 1596, comprou também uma das mais importantes casas na sua cidade natal, realocando para lá a sua família. HELIODORA, Barbara. Op. cit., p. $14-15$.

${ }^{63}$ Esse período compõe os chamados "anos perdidos" da vida do Bardo. Segundo Barbara Heliodora, "poucos assuntos tem dado lugar a tanta especulação quanto os famosos anos perdidos, isto é, os sete ou oito anos entre o nascimento dos gêmeos em Stratford e o primeiro documento sobre a vida profissional de Shakespeare em Londres" Ibid. p. 11.
} 
muralhas da cidade. Ficavam por isso perto de estabelecimentos fétidos, como fábricas de sabão, cola, curtumes e tinturarias. ${ }^{64}$

$\mathrm{O}$ ambiente dos teatros era peculiar e relativamente íntimo. Bill Bryson, estudioso em Shakespeare, relata que ninguém na plateia ficava mais de quinze metros do palco, o cenário era pouco e não havia cortina. ${ }^{65}$ Nenhum recurso havia para distinguir dia e noite, neblina e sol, campo de batalha da casa, a não ser as palavras. Por isso, as cenas eram situadas verbalmente e com ajuda da imaginação. Era preciso que o dramaturgo fosse bom o suficiente para trabalhar com um cenário econômico e dar brilho a cenas sem os recursos que se conhece hoje. Neste aspecto, Shakespeare se destacava. Os figurinos, em especial, eram muito valorizados em um ambiente sem cenário trabalhado.

Uma vez que se acredita que a chegada à Londres tenha sido entre 1587 e 1590, significa que Shakespeare não demorou para ter sucesso, já que a primeira referência feita a ele como autor teatral é de 1592: Trata-se do memorável ataque escrito por Robert Greene, um dramaturgo esquecido pelo teatro profissional. Estava revoltado com o florescer de Shakespeare, por este ser um dramaturgo sem educação universitária. Era um panfleto de conteúdo amargurado, distribuído com o intuito de alertar seus colegas dramaturgos sobre o "corvo arrivista, embelezado com nossas plumas, que com seu coração de tigre $^{66}$ envolto em pele de ator, supõe poder compor versos brancos tão bombásticos quando o melhor de vocês". ${ }^{67}$ Outra alusão ao Bardo foi o pedido de desculpas por parte do editor do panfleto, que esclareceu não conhecer o "senhor William Shakespeare", a quem, segundo ele, pessoas de respeito

\footnotetext{
64 "Fabricantes de cola e de sabão processavam grandes volumes de ossos e de gordura animal e enchiam o ar com o odor nauseabundo que podia ser tudo, menos eliminado enquanto os curtidores mergulhavam seus produtos em barris de fezes de cachorro para deixá-los macios. Ninguém chegava a um teatro sem passar por uma boa dose de cheiros.” BRYSON, Bill. Op. cit., p. 74.

${ }^{65}$ Ibid. p. 78.

66“'Coração de tigre faz referência a um verso da terceira parte de Henrique VI, que fala em "coração de tigre envolto em pele de mulher”. HELIODORA, Barbara. Op. cit., p. 12.

${ }^{67}$ Ibid. p 12.
} 
fizeram posteriormente as mais elogiadas referências. ${ }^{68}$

A partir de 1592, a documentação torna-se abundante. Encontra-se o nome de Shakespeare em registros não somente como dramaturgo, mas também como ator. Está na lista dos atores em documentos de 1592, 1598, 1603 e 1608, tendo se especializado em bons papéis, em suas próprias peças, ainda que as personagens que interpretava fossem razoavelmente pouco exigentes ${ }^{69} \mathrm{Não}$ se comparavam, por exemplo, com o desafio da interpretação de papéis femininos, já que, como os palcos eram proibidos para mulheres, os atores que as interpretavam tinham que ser bastante talentosos. ${ }^{70}$

Quando o nome de Shakespeare entra para os registros do teatro, estes são suspensos. Havia um surto de peste grave que levou os teatros de Londres a receberem ordem oficial de fechar as portas. Este período durou cerca de 2 anos e pelo menos 10 mil pessoas morreram em razão da peste. ${ }^{71}$ As companhias teatrais foram banidas de Londres e quanto a Shakespeare, tem-se outro mistério em relação ao o que o dramaturgo fazia nos anos da peste (1592 e 1593). O mais coerente é que Shakespeare permaneceu em Londres durante esse período, aproveitando para afirmar sua condição de poeta, preparando-se para a reabertura dos teatros. ${ }^{72}$

Sobre os anos da peste, existem teorias de que Shakespeare estava viajando pela Itália, o que justificaria a onda de peças italianas redigidas naquele período, incluindo "O Mercador de Veneza", que só viria a ser publicamente exposta em $1596 .{ }^{73}$ Apesar desta especulação, não há provas de que ele tenha

\footnotetext{
${ }^{68}$ Ibid. p 12.

${ }^{69}$ BRYSON, Bill. Op. cit., p. 83.

${ }^{70}$ Esse preconceito é uma tradição típica do norte da Europa. Na França, Espanha e Itália, por exemplo, mulheres podiam subir aos palcos para interpretar papéis femininos. Ibid. p. 80 .

${ }^{71}$ Ibid. p. 87.

${ }^{72}$ HELIODORA, Barbara. Op. cit., p. 12 - 13.

${ }^{73}$ A peça também é mencionada no livro Palladis tamia: Tesouro da Sabedoria, publicado de 1598, de um filósofo chamado Francis Meres. O livro cita Platão, Sêneca como os melhores autores latinos e Shakespeare como melhor autor inglês de comedias e tragédias, exemplificando com a peça "O Mercador de Veneza", o que permite que se afirme que a peça foi redigida nesta época, ao contrário de muitas outras peças de Shakespeare, que não possuem tempo certo. BRYSON, Bill. Op. cit., p. 98 - 99.
} 
viajado para outros países, sendo esta possibilidade pouco provável, uma vez que era necessária permissão oficial para viagens internacionais. ${ }^{74}$ Se resta a dúvida de como Shakespeare adquiriu tanto conhecimento de Veneza a ponto de escrever uma peça que se passa na cidade, com detalhes da época, a resposta é a mesma de como ele adquiriu conhecimento para escrever sobre períodos do passado histórico: através da leitura. ${ }^{75}$

Com o fim da peste, os teatros reabriram e as companhias se reorganizaram. Shakespeare entrou para a companhia de um jovem ator, Richard Burbage, se apresentando no Theatre, o primeiro teatro permanente construído em Londres, de propriedade do pai de Richard, James Burbage. Depois, em 1598, a companhia ocuparia o Curtain, mas já pensando em construir o próprio teatro. ${ }^{76}$ Aproveitariam a madeira do Curtain para mais tarde construir a sede do Globe que, em 1599, às margens do Tamisa, competiria com as outras casas de

\footnotetext{
74 "The other writers of his era who travelled in Europe tended to do so in a professional diplomatic or military capacity" MCGUIRE, Lauria; SMITH, Emma. Op. cit., p. 34. Tradução livre: Os outros escritores desta época que viajavam pela Europa normalmente faziam isto devido a motivos militares ou diplomáticos.

75 "But the answer, of course, to the question of how Shakespeare got his knowledge of these places is the same as the answer to a related puzzle - how did he "travel" to ancient Greece (A Midsummer Night's Dream, Timon of Athens, Troilus and Cressida), to ancient Rome (Julius Caesar, Coriolanus), to ancient Egypt (Antony and Cleopatra), ancient Britain (King Lear and Cymbeline), or to the England of the fourteenth and fifteenth centuries (the history plays from Richard II to Richard III)? Answer: He traveled through reading, conveyed by books. He didn't go to these places; he read about them" Ibid. p. 35. Tradução livre: A resposta, é claro, para a pergunta de como Shakespeare obteve conhecimento destes lugares é a mesma para um enigma semelhante: como ele "viajou" para Grécia Antiga, ("Sonho de uma noite de verão", "Timão de Atenas, "Troilo e Créssida") Roma Antiga ("Júlio César", "Coriolano"), Egito Antigo ("Antônio e Cleópatra"), Antiga Grã-Bretanha ("Rei Lear", "Cimbelino"), ou a Inglaterra dos séculos XIV e XV (peças históricas desde Ricardo II até Ricardo III)? A resposta é que ele viajava através da leitura, transportado por seus livros. Ele não ia a estes lugares, mas lia sobre eles.

76 "Terminara o período de arrendamento do terreno e o proprietário criava dificuldades para a renovação, já que ficaria com o teatro se as negociações não chegassem a bom termo." HELIODORA, Barbara. Op. cit., p. 13. Atualmente, preenchidos os requisitos da lei art. 51 da Lei 8.245/91, seria possível fazer uso da ação renovatória de contrato de locação comercial. Darcy Bessone de Oliveira Andrade explica: "O direito do comerciante à renovação do arrendamento resultou de uma aplicação da teoria do abuso de direito, emanada do legislador e assentada no critério da falta de motivo sério e legítimo. Firmou-se agora, em suma, que o senhorio, verificadas algumas condições, só poderá retomar o seu prédio quando se inspire nos motivos sérios e legítimos que a lei cautelosamente enuncia." ANDRADE, Darcy Bessone de Oliveira. Do direito do comerciante à renovação do arrendamento. Minas Genrais: Imprensa Oficial de Minas Gerais, 1940. p. 49.
} 
espetáculo. $^{77}$

Foi em 1594 que o sucesso de Shakespeare ficou claro (ainda que a profissão de dramaturgo não fosse tão estimada), com o patrocínio de um aristocrata importante e a dedicação exclusiva ao teatro. Infelizmente, seu filho Hamnet morreria 2 anos depois, aos 11 anos de idade. Foi nesse mesmo ano de 1596 que Shakespeare foi condecorado com um brasão, símbolo de ascensão social na Inglaterra, com o dizer "Non sanz droict" ${ }^{78} \mathrm{O}$ brasão não seria passado a diante na família em razão da morte do único filho homem.

Não se sabe ao certo como o Bardo reagiu à morte de Hamnet, mas com certeza não impediu que Shakespeare continuasse a caminho do sucesso. Apesar disso, a perda pode ser sentida em suas peças ${ }^{79}$ e também em suas ações, já que nove meses depois da morte do filho William comprou uma casa em Stratford, New Palace. Nessa época, já era um sujeito com boa situação financeira. Tornara-se um homem “de posses”. Era um cidadão respeitavelmente próspero, ainda que tenha deixado de pagar um tributo ou outro: no mesmo ano em que comprou a casa em New Palace, foi condenado em Londres por não pagar impostos (cerca de cinco xelins por dois anos consecutivos). ${ }^{80}$

Conforme mencionado, o ano de 1596 foi altamente perturbador para o Bardo, com a morte de seu filho, mas é precisamente o ano que interessa a este trabalho. É o período em que "O Mercador de Veneza" foi publicado. Existem

\footnotetext{
77 Giles Allen, o dono do terreno, precisou fazer uma pequena viagem e, durante sua ausência, os integrantes da companhia fizeram um mutirão e levaram toda a maneira que conseguiram para construir um novo teatro em outro terreno, que eventualmente seria o Globe. HELIODORA, Barbara. Os teatros no tempo de Shakespeare. In: LEÃO, Liana de Camargo; SANTOS, Marlene Soares dos (Org.). Shakespeare, sua época e sua obra. Curitiba: Beatrice, 2008. p. 69. Conforme supramencionado, feito uso da ação renovatória, estariam resguardados os investimentos feitos na infraestrutura do imóvel, não sendo necessário carregar a maior quantidade de madeira que os dramaturgos conseguiam transportar. 78 "Non sans droit" ou "Não sem o direito".

79 "Grief fills the room up of my absent child; Lies in his bed, walks up and down with me; Puts on his pretty looks, repeats his words; Remembers me of all his gracious parts; Stuffs out his vacant garments with his form." The life and death of King John. Ato III, Cena IV. Tradução livre: Tristeza enche o quarto do meu filho ausente, deita-se em sua cama, segue-me de um lado para o outro, imita sua bela aparência, repete suas palavras, me lembra de tudo que tinha de bom, preenche suas roupas vazias com sua forma.

${ }^{80}$ BRYSON, Bill. Op. cit., p. 123.
} 
teorias de que o motivo pelo qual a peça foi escrita, foi para chamar atenção à necessidade de reformas na Common Law. Tal não é, contudo, inteiramente preciso. Shakespeare não era um novelista de "solucionar problemas". Segundo George Willams Keeton, ${ }^{81}$ o dramaturgo era um homem muito ocupado, escrevendo peças para ganhar o "pão de cada dia". Por isso, problemas são apenas incidentais em suas peças, mas não o motivo para escrevê-las. Independente do motivo, é possível afirmar que Shakespeare estava atento aos problemas do seu tempo, inclusive os jurídicos. ${ }^{82}$

Segundo Tercio Sampaio Ferraz Júnior, a tragédia shakespeariana toma um sentido próprio na relação de poder e na questão delicada de mandar e ser obedecido. ${ }^{83}$ Para ilustrar essa questão é comumente fornecido o exemplo de Hamlet e Ricardo II. Ainda que o poder medieval se destaque, com a "concepção ritualística da realeza" 84 em relação à legitimidade, herança e laços de sangue, é possível estender essa concepção também para a plebe. Enquanto a relação de poder entre o soberano e os governados busca fundamento de origem divina ${ }^{85}$, as relações de poder entre governados se constituíam devido as interações sociais, com destaque para o poder exercido pelo credor perante o devedor.

As regras legais relacionadas a dívidas são frequentemente mencionadas por Shakespeare. Somado à severidade das leis durante o reinado de Elizabeth I está o fato de que muitos dos espectadores teatrais tremiam perante a ideia de irem para a prisão Fleet, em Londres, que servia especialmente para os

\footnotetext{
${ }^{81}$ KEETON, George Williams. Shakespeare and his legal problems. London: A \$ C. Black, 1930. p. 10. ${ }^{82}$ GUERREIRO. José Alexandre Tavares. Equidade em Shakespeare. In: ALQUÉRES, José Luiz; NEVES, José Roberto de Castro (Org.). Ele, Shakespeare, visto por nós, os advogados. Rio de Janeiro: Janeiro, 2017. p. 150.

${ }^{83}$ FERRAZ Jr., Tércio Sampaio. Os dois corpos do rei: o jogo da legitimidade. In: ALQUÉRES, José Luiz; NEVES, José Roberto de Castro (Org.). Ele, Shakespeare, visto por nós, os advogados. Rio de Janeiro: Janeiro, 2017.p .21.

${ }^{84}$ Expressão usada por Tércio Sampaio Ferraz Jr. Ibid. p. 21.

85 "Enquanto representante de Deus na Terra, o rei emprestava algo da natureza de Cristo: o corpo natural, submetido às vicissitudes da vida e o corpo místico ou político, de onde vinha a legitimidade do poder real.” Ibid. p. 22.
} 
devedores condenados por dívidas. ${ }^{86}$ Se alguém não podia pagar uma dívida, os credores tinham o direito de leva-lo a esta prisão, onde poderiam ficar por tempo indefinido. ${ }^{87}$ Para evitar escapatórias, até mesmo os carcereiros eram pessoalmente responsáveis por seus prisioneiros, de modo que se alguém escapasse, seriam eles os obrigados pelas dívidas dos fugitivos. ${ }^{88}$

Assim, havia grande simpatia por peças nas quais as personagens passavam por dificuldades financeiras em razão de dívidas. Eram, aliás, muito comuns, em razão da inexistência de mútuo por parte de instituições financeiras. Levando em conta também a experiência do próprio Shakespeare ao ver o pai lutar contra dívidas, não há grande surpresa que este seja um tema recorrente em suas obras, tendo em vista ser uma questão presente na vida dos ingleses. Para a audiência elisabetana, Shylock representa o praticante de usura do dia a dia, que levava o devedor à ruina. ${ }^{89}$ Segundo Keeton, se fosse possível ver o rosto dos jovens nobres assistindo as peças no Globe, estaria refletido em seus olhares mais do que um calafrio apreensivo ao se verem em situações tão similares quanto a de Antônio. ${ }^{90}$

O que Shakespeare fez foi transportar os problemas locais que conhecia para uma cidade pela qual demonstrava enorme fascínio: Veneza. A expansão

\footnotetext{
86 Construída em 1197 às margens do Rio Fleet. <http://www.british-history.ac.uk/old-newlondon/vol2/pp404-416> acesso em 08 out. 2017.

${ }^{87}$ De acordo com George Keeton, não era diferente na Roma ou Grécia. Nestes locais, também o devedor poderia ser emprisionado por seus credores. KEETON, George Williams. Op. cit., p. 86. O Direito romano ganha destaque nesse quesito. Ainda que a redução do devedor à escravidão tenha sido abolida com a Lex Poetelia Papiria, restaram resquícios de um sistema onde o devedor era pessoalmente obrigado pelas dívidas. De acordo com Caio Mário, o conceito de obrigação já era bastante apurado nos primeiros tempos romanos e foi logo nitidamente formulado como um iuris vinculum hábil a prender um devedor a um credor. No período clássico, o poder do credor sobre o devedor (nexum) significava poder sobre o corpo de sentido de escravizar. PEREIRA, Caio Mario da Silva. Instituições de Direito Civil: Teoria Geral das Obrigações. $25^{\text {a }}$ ed. Rio de Janeiro: Forense, 2012. v. 2. p. 9 - 10. De acordo com as lições de Eberto Viana Chamoun, o nexum, inicialmente um empréstimo, tornou-se mais tarde um processo para criar quaisquer obrigações em dinheiro, no qual o contrato por si só já tinha força executória. Autoriza o credor a prender o devedor em sua prisão doméstica por 60 dias, acorrentando-o e fazendo-o trabalhar. Se este prazo se esgotasse sem pagamento ou acordo, poderia o credor matar o devedor ou vendê-lo como escravo no rio Tibre. CHAMOUN, Ebert Viana. Instituições de Direito Romano. $3^{\mathrm{a} e d .}$ Rio de Janeiro: Revista Forense, 1957. p. 358.

${ }^{88}$ KEETON, George Williams. Op. cit., p. 80.

${ }^{89}$ Ibid. p. 16.

${ }^{90}$ Ibid. p. 16.
} 
do mercantilismo depois da Idade Média fez com que Veneza se tornasse uma das mais prósperas cidades no quesito mercantil. ${ }^{91}$ Segundo Selma Ferreira Lemes, ao escolher a Sereníssima (como era conhecida a República de Veneza entre o século IX até meados de 1797, quando foi vencida por Napoleão ${ }^{92}$ ), o dramaturgo elege como palco de suas histórias o início da Era Moderna, das invenções, dos descobrimentos científicos, dos exploradores, do Renascimento e do Humanismo, tendo como plano de fundo o mercantilismo. ${ }^{93}$

Para compreender porque o dramaturgo transportou suas histórias para outra época e local, deve-se pensar na conexão entre a cartografia, a história, a geografia e a humanística, não só em Veneza, mas também no ambiente no qual se inseria o próprio bardo. A questão comercial chamara a atenção de Shakespeare, pois era importante também na Inglaterra. O Bardo presenciou o surgimento da letra de câmbio, dos primeiros bancos e do Direito Mercantil representado na Lex Mercatoria e Ius Mercatorum (fundado na prática e costumes dos mercadores). Também teve início a arbitragem comercial internacional, influenciando a elaboração de regras mercantis mediterrâneas. ${ }^{94}$

A introdução da moeda como novo personagem central, cercada pelas relações comerciais proporcionou novos dilemas em relação ao mercantilismo e à Law Merchant, que sucedeu a antiga Lex Mercatoria da Idade Média. À Common Law foram incorporadas práticas justas e uma nova forma de interpretação e aplicação legal, principalmente a partir do século XVI, quando o movimento Equity se cristalizaria como parte integrante da lei, dando verdadeiro sentido à expressão "ex bono et aequo" ${ }^{95}$. Segundo José Alexandre Tavares a

\footnotetext{
${ }^{91}$ A ilha de Chipre era uma colônia de Veneza e também foi escolhida pelo dramaturgo para ser palco de outra peça, "Otelo". LEMES, Selma Ferreira. Shakespeare e Veneza, o retrato do tempo. In: ALQUÉRES, José Luiz; NEVES, José Roberto de Castro (Org.). Ele, Shakespeare, visto por nós, os advogados. Rio de Janeiro: Janeiro, 2017. p. 121.

${ }^{92}<$ http://metahistoria.com/novedades/venecia-ciudad-de-fortuna-rb/> acesso em 08 out. 2017.

93 LEMES, Selma Ferreira. Op. cit., p. 122.

${ }^{94}$ Ibid. p. 122.

${ }^{95}$ Em tradução livre, “conforme o correto e válido", ou seja, confere-se à decisão validade no julgamento pela equidade, desde que seja justa.
} 
aplicação da equidade pelo Doge de Veneza representa uma concepção inovadora da ordem jurídica e é um dos altos momentos do teatro Shakespeariano. ${ }^{96}$

Se estes já não fossem motivos suficientes para um cenário ideal, somase o fato de que Veneza era uma cidade verdadeiramente cosmopolita, com diversidade cultural e étnica suficiente para que fossem ouvidas várias línguas na rua, como o veneziano, turco, grego e alemão. Judeus, cristãos e mulçumanos conviviam em uma mesma cidade, ainda que os venezianos fossem intolerantes com os judeus e mouros. ${ }^{97}$ Neste ambiente cultural multifacetado, somado às circunstâncias jurídicas decorrentes da insuficiência da lei escrita para a resolução dos conflitos interpessoais, foi onde nasceu o contexto perfeito para a trama entre Shylock e Antônio. Uma vez encontrado o cenário perfeito, a relação credor-devedor e o princípio pacta sunt servanda jamais seriam os mesmos ${ }^{98}$.

Após o reinado de Elizabeth I, que terminou em 1603, Shakespeare produziu várias outras peças brilhantes. Ainda que seja categorizado como um dramaturgo elisabetano, a maior parte de suas peças é produzida sob a monarquia de James I. A cadeia de tragédias merece atenção especial, dentre elas “Otelo", "Rei Lear", "MacBeth", “Antônio e Cleópatra" e "Coriolano”. A partir de 1609 o número de peças escritas diminui consideravelmente e Shakespeare se retira para Stratford em $1612 .{ }^{99}$

\footnotetext{
${ }^{96}$ GUERREIRO, José Alexandre Tavares. Op. cit., p. 147.

${ }^{97}$ LEMES, Selma Ferreira. Op. cit., p. 123.

${ }^{98} \mathrm{O}$ que se aprende com Shakespeare pode não ser de grande surpresa para o direito contemporâneo, mas é preciso reconhecer que a obra, em pleno século XVI, trata de uma questão que traz repercussões complexas e atuais acerca da pactuação de direitos existenciais e da dignidade da pessoa humana. Como bem afirmou Italo Calvino, "O clássico não necessariamente nos ensina algo que não sabíamos; às vezes descobrimos nele algo que sempre soubéramos (ou acreditávamos saber) mas desconhecíamos que ele o dissera primeiro (ou que de algum modo se liga a ele de maneira particular). E mesmo esta é uma surpresa que dá muita satisfação, como sempre dá a descoberta de uma origem, de uma relação, de uma pertinência.": CALVINO, Italo. Por que ler os clássicos. $2^{\mathrm{a}}$ ed. Trad. Nilson Moulin. São Paulo: Companhia das Letras, 2007. p. 12.

${ }^{99} \mathrm{Em} 11$ do mesmo ano, Shakespeare foi testemunha do caso Belott-Montjoy, onde o genro exigia do sogro o pagamento que lhe fora prometido. Na época em que a disputa se iniciou, 8 anos antes, o Bardo era inquilino de Christopher Montjoy. Documentos on-line do julgamento mostram uma das assinaturas conhecidas do dramaturgo: $<$ http://www.shakespearedocumented.org/exhibition/document/bellott-vmountjoy-first-set-depositions-bellotts-behalf-including-shakespeares $>$ acesso em 06 nov. 2017.
} 
Existem registros de 1616 acerca das mudanças que Shakespeare fez em seu testamento, no mesmo ano de sua morte. São três folhas de pergaminho, trazendo seis das assinaturas conhecidas do dramaturgo, uma em cada página. Hoje, o testamento está depositado em uma sala especial nos Arquivos Nacionais Britânicos, em Kew, Londres. ${ }^{100}$ Foram deixadas 350 libras em dinheiro, quatro casas e considerável quantidade de terra. Era um espólio respeitável para a época, mas nada realmente grande, apesar do inventário total ter perecido no Grande incêndio de Londres, em 1666. ${ }^{101}$

A linhagem de Shakespeare não durou por muito tempo, morrendo junto com sua neta, em $1670 .{ }^{102}$ Esta era uma pessoa que poderia ter preenchido algumas lacunas sobre a vida do bardo, se não fosse pelo fato de que a primeira tentativa de biografia do dramaturgo surgiu somente em 1709, por Nicholas Rowe. ${ }^{103}$ Hoje, apesar da inquieta série de mistérios que ainda rodeiam sua figura, William encontra descanso na capela da Santíssima Trindade. É o mesmo local onde está o busto de tamanho natural produzido por Gheerart Janssen. A escultura retrata Shakespeare com caneta e papel em mãos, com o seguinte poema:

\footnotetext{
"Stay passenger, why guest thou so fast?

Read, if thou canst, whom envious death hath placed

Within this monument: Shakespeare, with whom

Quick nature died, whose name doth check this tomb

Far more than cost, sith all that he hath writ

Leaves living art but page to serve his wit."104
}

Ao final, resta justificada a fascinação pelo menino de Stratford-upon-

\footnotetext{
${ }^{100}$ BRYSON, Bill. Op. cit., p 151.

${ }^{101}$ Ibid. p. 151.

102 Ibid. p. 154.

103 Ibid. p. 170.

104 “Alto, passante, por que marchas tão rápido? Lê, se podes, quem pôs a invejosa morte neste monumento: Shakespeare, com quem morre a natureza e cujo nome bem mais que ouro orna esta tumba, e o que escrevia faz da arte tábua rasa à sua sabedoria.” Tradução por Bill Bryson. Ibid. p. 177.
} 
Avon que veio a ser um dos maiores dramaturgos de todos os tempos. ${ }^{105} \mathrm{Tem}-$ se em Shakespeare um dramaturgo sem igual, pois era indubitavelmente um mestre na arte de criar, moldar e construir, não somente poemas e peças, mas também gente. Sua fama foi e é alimentada pela capacidade de, através de personagens que refletiam as pessoas e a história que o cercavam, cultivar situações que entrelaçavam a tragédia e a comédia que é a vida cotidiana. Fazia tudo isso de maneira íntima e cativante. Shakespeare é Shakespeare porque suas obras são a imagem caricata da própria existência humana.

Para o Direito interessa profundamente a desordem shakespeariana por trás do mundo dos homens. Devido às relações destes surgem os conflitos e nasce a necessidade da instauração da ordem por meio da lei. Recai na essência conflituosa da condição humana o motivo pelo qual as obras do dramaturgo são impregnadas com o fascínio pelo jurídico e, ao mesmo tempo, é a razão pela qual os juristas se deleitam na expressão artística do Direito por meio da Literatura.

\footnotetext{
${ }^{105}$ Em resposta à indagação de Frank Halliday: "What then? What remained? Why all this pother about a provincial boy who made a fortune out of the theatre?" HALLADAY, Frank Ernest. Shakespeare and his world. $5^{\text {a }}$ ed. Londres: Thames \& Hudson, 1979. p. 116. Tradução livre: Então o quê? O que restou? Por quê toda a agitação sobre do menino provincial que fez uma fortuna com os teatros?
} 


\section{CAPÍTULO 2 - O MERCADOR DE VENEZA E O DIREITO}

\subsection{O mútuo}

O enfoque dos problemas jurídicos é refletido nas peças de Shakespeare de tal maneira que muitos até acreditam que as obras tenham sido escritas por um autor conhecedor do Direito, ou seja, alguém que perseguia uma carreira jurídica. Ainda que não haja evidências suficientes para afirmar que Shakespeare foi, de fato, advogado, ou conectado com o Direito de maneira relacionada ao labor legal, pode-se dizer seguramente que muitas de suas obras são lastreadas de bagagem jurídica. "O Mercador de Veneza” é, sem dúvida, uma delas. No entanto, para compreender o aspecto jurídico da peça, deve-se, primeiro, abarcar a trama.

A primeira cena tem início com a seguinte frase: "Na verdade, eu não sei porque estou tão triste"106. São estas as palavras de Antônio, um próspero comerciante da burguesia Veneziana do séc. XIV. ${ }^{107} \mathrm{O}$ motivo de sua tristeza não é relacionado a seu trabalho, pois ele aguarda o retorno de seus navios mercantes lançados ao mar, que certamente lhe trariam, ao acostar, o lucro esperado. É certo que a frase de Antônio introduz os acontecimentos desafortunados que se desenrolam a partir desta primeira passagem.

\footnotetext{
106“In sooth, I know not why I am so sad" “O Mercador de Veneza”: Ato I, Cena I.

$107 \mathrm{Na}$ época, Veneza era uma das cidades mais prósperas do mundo, graças ao comércio. Daí o fascínio de Shakespeare pela cidade, que era a mais antiga da República da Europa, havendo o apogeu do comércio com a expansão do mercantilismo. Ainda mais, era o único Estado que dirigia as políticas de governo para fins econômicos. "Era uma cidade à frente de seu tempo". LEMES, Selma Ferreira. Shakespeare e Veneza, o retrato do tempo. In: ALQUÉRES, José Luiz; NEVES, José Roberto de Castro (Org.). Ele, Shakespeare, visto por nós, os advogados. Rio de Janeiro: Janeiro, 2017. p. 119- 137.
} 
A desventura tem início com a revelação que Antônio recebe de Bassânio, um grande amigo ${ }^{108}$. Bassânio precisa de dinheiro para cortejar Pórcia, uma dama que receberá pretendentes para tomar sua mão em casamento. Pórcia vem de uma família próspera e, casando-se com ela, Bassânio ficaria, sem dúvidas, bastante afortunado, mas, para isso, precisa viajar até Belmonte, onde está a moça e deveria ter dinheiro suficiente para cortejá-la. ${ }^{109}$ Antônio explica que suas fortunas estão imobilizadas no mar, pois seus navios mercantes ainda não retornaram e que não possui dinheiro para realizar o mútuo. No entanto, procurando ajudar, diz a Bassânio que tente verificar quais empréstimos pode conseguir na cidade de Veneza, anunciando ele, Antônio, como seu fiador. ${ }^{110}$ Promete, ainda, que não fará imposições à escolha de Bassânio. ${ }^{11}$

O azar de Antônio recai sobre o fato de que, ao procurar alguém que lhe emprestasse o dinheiro que precisava para viajar até Pórcia, Bassânio encontra

\footnotetext{
${ }^{108}$ Há certa confusão na relação entre Antônio e Bassânio e há teorias de que na verdade Antônio fosse apaixonado pelo amigo e por isso se arriscaria para ajudá-lo.

${ }^{109}$ Imprescindível destacar que o que impulsionava Bassânio não era o amor pela moça que sequer conhecia, e sim a fortuna desta jovem herdeira. Seu objetivo é puramente econômico: recuperar a riqueza que um dia tivera, mas que não soube administrar em meio à vida boêmia que o levou à ruina financeira. ${ }^{110}$ As garantias bancárias são hoje realizadas em grande escala. Vera Helena de Mello Franco explica em relação aos bancos, que as operações de crédito são realizadas em massa, com características constantes e uniformes, segundo tipos negociais estandardizados. FRANCO, Vera Helena de Mello. Contratos: Direito civil e empresarial. $4^{\mathrm{a}}$ ed. São Paulo: Revista dos Tribunais, 2013. p. 227. A oferta de Antônio à Bassânio se aproxima da relação bancária e não é incomum para a época, uma vez que os próprios comerciantes realizavam estes empréstimos em larga escala, na falta de instituições financeiras como se tem hoje. Assim como as instituições bancárias, a posição de Antônio como fiador é confiável, uma vez que era conhecido por ser um próspero comerciante. Independente da época, o requisito essencial do fiador é, por óbvio, ter capacidade de pagar a dívida, caso o devedor não o faça, tal qual dispõe o art. 825 do Código Civil de 2002: "Quando alguém houver de oferecer fiador, o credor não pode ser obrigado a aceitá-lo se não for pessoa idônea, domiciliada no município onde tenha de prestar a fiança, e não possua bens suficientes para cumprir a obrigação".

${ }^{111}$ É no momento desta promessa que Bassânio sela sua maior desventura. O perigo recai no fato da fiança amarrar credor e fiador, constituindo relação distinta daquela que se cria entre credor e afiançado. Ao prometer que não se oporia ao credor escolhido, Antônio se propõe a firmar negócio jurídico com qualquer indivíduo na cidade de Veneza. É desatento para o fato de que, tal como o credor pondera minuciosamente a escolha do fiador, este também deveria se atentar à pessoa do credor. "A fiança conclui-se entre fiador e credor. O contrato principal, entre o credor e o afiançado, constitui outra relação jurídica. Se é frequente o devedor procurar e solicitar quem lhe garanta a solvência, e se não é raro conter-se a fiança no corpo do contrato principal, como cláusula deste, não se descaracteriza subjetivamente. Pode, mesmo, ser estipulada na incidência e até contra a vontade do devedor, sem sofrer degradação e não tem o afiançado a liberdade de recusá-la sob invocação do princípio invito non datur beneficium (não se faz benefício ao que não quer)" PEREIRA, Caio Mario da Silva. Instituições de Direito Civil. Vol. III. $17^{\mathrm{a}}$ ed. Rio de Janeiro: Forense. 2013. p. 258.
} 
Shylock. ${ }^{12} \mathrm{O}$ encontro dos dois tem início já com a discussão do preço e das condições do mútuo: três mil ducados ${ }^{113}$ por três meses e Antônio como fiador. Shylock aceita os termos e a fiança, mas antes pede para falar com Antônio. Nesse momento, Bassânio sugere um jantar entre os três e é nessa hora que se compreende a rivalidade existente por trás do empréstimo. Apesar de Shylock aceitar Antônio como fiador, nega-se a juntar-se a eles para comer e o faz de maneira bastante rude ${ }^{114}$.

Os motivos da rivalidade ${ }^{115}$ entre Shylock e Antônio não podem ser calcados em um só acontecimento. São vários os fatores que contribuem para a disparidade entre as duas personagens: Shylock é judeu e Antônio é católico. Antônio faz empréstimos sem cobrar juros, o que prejudica os negócios de Shylock. ${ }^{116}$ Além disso, Shylock expressa os maus tratos sofridos de todos aqueles que, como Antônio, inclusive este, o xingaram e zombaram em razão de ser judeu. Assim, Shylock o provoca, indagando se deve abaixar a cabeça e emprestar dinheiro àquele que "o chamara de cão tão somente na quarta-feira

\footnotetext{
${ }^{112} \mathrm{O}$ motivo pelo qual Bassânio não se dirigiu a uma instituição bancária para pedir o empréstimo é que estas ainda não existiam no século XIV. Jacques Heers explica que eram chamados "banqueiros" os homens de negócios que tinham um banco na praça pública, que recebiam depósitos de seus fregueses e concediam empréstimos. Segundo Heers, o homem de negócios nesta época se assemelha mais a um "manipulador do dinheiro" do que propriamente o chefe de empresa que se tem hoje. Ainda assim, é a figura mais aproximada do empresário contemporâneo. Trata-se um novo tipo de mercador, "o grande mercador", que se distancia da figura do viajante que cruzada as estradas do mundo com suas mercadorias, que fiscalizava seus armazéns à espera dos navios. Havia uma nova mentalidade para dirigir os negócios através do dinheiro. HEERS, Jacques. O ocidente nos séculos XIV e XV: aspectos econômicos e sociais. Tradução de Anne Arnichand da Silva. São Paulo: Pioneira, 1981. p. 179.

${ }^{113} \mathrm{O}$ ducado é uma moeda de ouro ou prata e seu valor pode variar. GREENWOORD, Cynthia. The Complete guide to Shakespeare's plays. Nova Iorque: Alpha, 2008. p 90.

114 "I Will buy with you, sell with you, talk with you, walk with you, and so following, but I will not eat with you, drink with you, nor pray with you." "O Mercador de Veneza": Ato I, Cena III. Tradução livre: "Eu comprarei com vocês, venderei com vocês, falarei com vocês, andarei com vocês assim por diante, mas eu não comerei com vocês, não beberei com vocês, nem rezarei com vocês".

115 Tem-se uma rivalidade entre dois comerciantes: "O comerciante outro não é senão a mesma pessoa, natural, ou jurídica, apta para o exercício de direitos e obrigações de ordem privada, a praticar, habitual e profissionalmente, a atividade mercantil." Significa que o distingue os comerciantes é a atividade profissional. MARTINS, Fran. Contratos e obrigações comerciais. 14 ed. Rio de Janeiro: Forense, 1998. p. 5 .

${ }^{116}$ I hate him for he is a Christian! But more, for that, in low simplicity, he lends out money gratis, and brings down the rate of usance here with us in Venice." "O Mercador de Veneza": Ato I, Cena III. Tradução livre: Eu o odeio porque é cristão! E mais, para isso, em baixa simplicidade, ele empresta dinheiro gratuitamente e reduz a taxa de usança aqui conosco em Veneza.
} 
passada". ${ }^{117}$ Antônio responde com ainda mais intolerância, afirmando que o faria de novo: xingaria, cuspiria e o desprezaria novamente. ${ }^{118}$

Desse modo, a conversa sobre a fiança tem início com a exposição das inimizades e termina de maneira menos agradável ainda. Shylock convida Antônio a ir ao notário e lá selar o mútuo com a seguinte cláusula: se o montante não for pago no dia acordado, uma libra de carne de Antônio deverá ser cortada e dada como pagamento. ${ }^{119} \mathrm{Tem}$-se, neste momento, a estipulação da cláusula penal assessória, que deveria ser cumprida caso a obrigação principal fosse inadimplida. ${ }^{120}$ Analisando a atitude de Shylock, a cláusula penal não tinha

117 "O Mercador de Veneza”: Ato I, Cena III.

${ }^{118}$ Harold C. Goddard se pergunta como poderia um dos espíritos mais tolerantes da história, que era Shakespeare, ter escrito uma peça centrada em um dos maiores preconceitos de todos os tempos que é o antissemitismo. CLARKE. Harold Goddard. The meaning of Shakespeare. $5^{\mathrm{a}}$ ed. v 1. Chicago: University of Chicago Press, 1965. p. 81. No século XIV, Veneza era uma cidade na qual os judeus sofriam muito preconceito, o que dificultava os negócios. Para sobreviveram, uma prática muito comum era o empréstimo com juros (usura), que era condenada pela igreja católica, visto como espécie de enriquecimento ilícito, pois não requeria nenhum esforço do comodante. Somente então, com o contexto da época, deve-se tomar conclusões sobre Shylock. Os métodos por este empregados ao longo da trama podem não ser justificados unicamente pelo tratamento recebido durante toda a vida (ao longo da peça, é chamado de "diabo encarnado", “judeu ordinário", cão judeu”, "feroz judeu”, membro de uma raça "pagã", como se fosse um sub-humano, digno de insultos durante toda a trama), mas são certamente explicados pela conformidade com o contexto histórico, com as práticas e costumes da época e, mais importante, com a lei vigente.

119 Note-se que a operação ocorre de maneira semelhante ao mútuo bancário, definida como “operação pela qual o Banco entrega a terceiros uma certa soma em dinheiro para ser devolvida dentro de um prazo determinado, cobrando juros para tanto." Mais ainda, "O mútuo bancário é, em princípio, um mútuo de destinação", ou seja, possui finalidade específica. FRANCO, Vera Helena de Mello. Contratos: Direito civil e empresarial. 4a ed. São Paulo: Revista dos Tribunais, 2013, p. 164, 167. No lugar dos juros, movido pela arrogância, Shylock preferiu humilhar o fiador ao cobrar a libra de carne, o que não deixa de ser uma onerosidade acessória ao objeto principal. Quanto à destinação, esta consiste no investimento de Bassânio que, com objetivos financeiros, precisa ser financiado em sua viajem. José A. Engrácia Antunes designa por "empréstimo mercantil ("comercial loan", Handelsdarlehen", "prêt comercial", "préstamo mercantil") o contrato pelo qual uma das partes entrega ou se obriga a entregar à outra, dinheiro ou coisa fungível destinada a qualquer atividade comercial, ficando a última obrigada à respectiva restituição", ficando o mutuante obrigado a aplicar tais quantias ou coisas em uma operação comercial concreta. ANTUNES. José A. Engrácia. Direito dos Contratos Comerciais. Coimbra: Almedina, 2009. p. 368. Importante destacar que as três personagens, Antônio, Shylock e Bassânio, possuem perspectivas econômicas diante desta transação. Antônio e Shylock são comerciantes e concedem empréstimos para os habitantes de Veneza enquanto Bassânio almeja se tornar rico novamente mediante um contrato de casamento, caracterizando o aspecto comercial de sua jornada até Pórcia.

120 "No Código Civil de 1916, a cláusula penal encontrava-se inserida no capítulo das modalidades de obrigações. O Código Civil de 2002 consertou o equívoco para, corretamente, colocar esse tipo de estipulação no capítulo referente à inexecução. De fato, a cláusula penal apenas será eficaz diante da inexecução. Antes, ela fica aguardando, em potência, para incidir somente se o devedor falhar no cumprimento de sua obrigação" NEVES, José Roberto de Castro. Direito das Obrigações. $3^{\mathrm{a}}$ ed. Rio de Janeiro: GZ, 2012. p. 378 . 
simplesmente o objetivo de assegurar e estimular o pagamento. Muito menos funcionava como pré-avaliação dos danos, fazendo liquidação prévia do montante indenizatório no caso de prejuízos ao credor oriundos da inadimplência. No fundo, Shylock desejava o inadimplemento e almejava a cobrança da cláusula acessória, ainda mais do que a principal. ${ }^{121}$

Movido pela convicção de que conseguiria realizar o pagamento e, mais ainda, pela arrogância, não querendo recuar perante aquele que o desafiava, Antônio aceita os termos, certo de que nada de imprevisível aconteceria. ${ }^{122}$ No entanto, estava enganado. A atitude precipitada de Antônio foi ignorar que a espécie de pacto a ser firmado seria semelhante ao contrato aleatório, uma vez que seus navios poderiam não retornar a tempo. ${ }^{123} \mathrm{~A}$ opção por esta espécie contratual seria sua ruína devido à álea convencionada. ${ }^{124}$

Enquanto para Bassânio o plano de cortejar Pórcia em Belmonte segue do jeito esperado, Antônio permanece em Veneza com um grande problema: Seus navios ainda não retornaram e o pagamento deve ser realizado. Assim,

\footnotetext{
${ }^{121}$ Nem todas as relações mercantis possuíam este condão negativo. Muitas operações se realizavam inclusive oralmente, pois os mercadores conheciam-se entre si e os negócios se estabeleciam a partir de confiança mútua. HEERS, Jacques. Op. cit., p. 179.

${ }^{122}$ Apesar da relutância de Bassânio, que alerta Antônio a não firmar tal pacto em seu nome, este não teme o perigo. Antônio tinha a certeza de que seus navios mercantes ancorariam um mês antes do termino do prazo e que retornariam então com muito mais do que a quantia de três mil ducados, de modo que teria dinheiro suficiente para pagar Shylock.

123. "Sob o aspecto estrutural, os contratos aleatórios se caracterizam, em regra, pela indeterminação $a b$ initio da prestação de uma ou ambas as partes em seu an ou quantum, de tal maneira que a existência ou a determinação física da prestação depende da ocorrência de evento incerto". BANDEIRA, Paula Greco. Contratos Aleatórios no Direito Brasileiro. Rio de Janeiro: Renovar, 2010. p. 254. Pensando em contratos mercantis, pode-se afirmar que o contrato por si só é um instrumento de alocação de riscos referentes à atividade econômica. As pactuações empresariais envolvem riscos pela própria natureza econômica do negócio, uma vez que o contrato é um empreendimento sobre o futuro. FORGIONI, Paula A. Teoria geral dos contratos empresariais. $2^{\circ}$ ed. São Paulo: Revista dos Tribunais, 2010. p. 136.

124 "Pode-se afirmar que, no direito brasileiro, a álea consiste em elemento essencial aos contratos aleatórios e, por isso mesmo, consubstancia-se em traço distintivo de sua causa, determinando a disciplina jurídica que lhes é aplicável. Assim sendo, a álea deve ser compreendida pela incerteza de ambos os contratantes, existente no momento da celebração do negócio, quanto ao lucro ou prejuízo, em termos de atribuição patrimonial, que dele decorrerá, a depender da verificação de evento incerto e incontrolável, embora previsto pelas partes". BANDEIRA, Paula Greco. Op. cit., p. 25. Pela perspectiva mercantil, se o contrato em questão for considerado entre dois empresários, a racionalidade limitada não é estranha. Segundo Paula Forgioni, o empresário não é capaz de prever todos os eventos futuros no curso da relação, tendo o direito mercantil sempre reconhecido a impossibilidade de detenção de todas as informações relacionadas à transação e ao futuro. FORGIONI, Paula A. Op. cit., p. 66, 69.
} 
Antônio tenta falar com Shylock, que se recusa a ouvir qualquer explicação, demandando que os termos pactuados sejam cumprimos conforme o acordado, ou seja, exigindo a libra de carne do fiador. ${ }^{125}$ Dessa maneira, Shylock se mostra disposto a levar à questão ao Doge (maior autoridade jurídica de Veneza) para receber sua garantia.

Apesar de um dos amigos de Antônio the garantir que o Doge certamente não concederá a garantia, Antônio está certo de que o curso das leis não será impedido. Explica que, se assim o fosse, a justiça do Estado ficaria comprometida aos olhos de mercadores de outras nações, cujo comércio contribui para a riqueza na cidade de Veneza. Estava convencido de que seria condenado a garantia e reza para que Bassânio venha ao seu encontro e o presencie, sem dar importância ao que aconteceria depois. ${ }^{126}$

\subsection{O julgamento}

Bassânio, sabendo da cobrança da dívida, volta para Veneza a tempo do julgamento e, seja por ironia ou por coincidência, o título do ato seguinte é: "Veneza. Uma Corte de Justiça". Aqui, estamos diante do ponto central da trama: o que seria fazer justiça diante de Antônio e Shylock ${ }^{127} \mathrm{O}$ cumprimento do contrato exegeticamente, com a retirada da libra de carne do fiador ou a

\footnotetext{
125 "I'll have my bond, speak not against my bond. I have sworn an oath that I will have by bond" "O Mercador de Veneza”: Ato III, Cena 3. Tradução livre: Eu terei minha garantia, não me impeça! Eu fiz um juramento que terei minha garantia!

126 "Pray God, Bassanio come to see me pay his debt and then I care not!" "O Mercador de Veneza": Ato III, Cena IV. Tradução livre: Por Deus! Que Bassanio venha me ver pagar minha dívida e o que acontece depois eu não me importo.

${ }^{127}$ A resposta não é simples, pois, como exposto por Rawls, as pessoas dispõem de posições sociais diferentes às quais estão sujeitas desde o seu nascimento. Isso afeta suas expectativas de vida a partir da percepção de que algumas pessoas têm mais ou menos sorte que outras na distribuição das posições sociais. Isso influencia a perspectiva de cada um sobre a definição do que seria justo. RAWLS, John. Uma Teoria da Justiça. Tradução de Almiro Pisetta e Lenita M. R. Esteves. $2^{\mathrm{a}}$ ed. São Paulo: Martins Fontes, 2000. p.101.
} 
invalidade da cláusula que estipula o pagamento com parte do corpo, ao esgotar o prazo para o adimplemento?

A dúvida é fortalecida uma vez que o ordenamento jurídico veneziano não atrelava o exercício jurídico à realização de valores sociais. Ou seja, não restringia a livre iniciativa, nem lhe impunha limites externos ou condições de legitimação, como ocorre atualmente, onde o Direito Civil e especialmente o contratual devem se ajustar aos valores constitucionais. ${ }^{128}$ Seja como for, o julgamento tem início com a demonstração de solidariedade por parte do Doge de Veneza, que expressa o quanto sente por Antônio naquela situação ${ }^{129}$. Isso mostra que a invalidade ou validade da cláusula não estava em questão. A cláusula era válida e isso era de conhecimento de todos. Se restasse dúvida, não teria o Doge pedido a Shylock que mostrasse piedade. ${ }^{130}$

Apesar da misericórdia pleiteada pela Corte $^{131}$, o julgamento prossegue com a oitiva de Shylock, que se mantém firme em sua posição, esperando nada a menos do que a garantia que lhe é devida. Mesmo quando Bassânio intervém (e agora era um homem rico em virtude do casamento com Pórcia), oferecendo seis mil ducados no lugar dos três mil originalmente acordados, Shylock recusa. A cada pedido de misericórdia e a cada oferta que recebe, almeja ainda mais a libra de carne, tendo sempre uma resposta para recusar que seja de outro

\footnotetext{
128 “A centralidade do valor da pessoa humana, consagrado pela Constituição, impõe nova consideração sobre as relações patrimoniais, onde a tutela da saúde, o meio ambiente e a paisagem são indispensáveis para o total desenvolvimento da pessoa, movimento esse que vem se chamando despatrimonialização." SANTOS, Deborah Pereira dos; MENDES, Eduardo Heitor. Função, funcionalização e função social. In: SCHREIBER, Anderson; KONDER, Carlos Nelson. Direito Civil Constitucional. São Paulo: Atlas. 2016. p. 104.

129 "I am sorry for thee: though art come to answer. A stony adversary, an inhuman wretch" "O Mercador de Veneza": Ato IV, Cena I.

130 "But, touch'd with human gentleness and love, forgive a moiety of the principal, glancing an eye of pity on his losses (...) we all expect a gentle answer, Jew" "O Mercador de Veneza”: Ato IV, Cena I.

${ }^{131}$ A misericórdia pleiteada pela Corte tratava de remissão da dívida concedida somente ao fiador, de modo que o devedor continuaria obrigado e Shylock ainda assim poderia cobrar do afiançado. "Assim é que a remissão da dívida concedida ao devedor principal extingue a fiança; mas se for dada ao fiador, libera-o, sem fazer cessar a relação obrigatória fundamental" PEREIRA, Caio Mário da Silva. Instituições de Direito Civil. Vol. III. 17 $7^{\mathrm{a}}$ ed. Rio de Janeiro: Forense, 2013. p. 464.
} 
modo. ${ }^{132}$

Shylock questiona, ainda, a segurança proporcionada pelos decretos de Veneza, caso não lhe seja entregue o que é seu por lei: "Se me negar, vergonha perante vossa lei! Não há vigor nos decretos de Veneza!"133 Essa é uma das passagens mais importantes deste ato, pois Shylock procura constranger o Doge perante o Tribunal e toda Veneza, protestando diante do fato de que, se não pudesse cobrar a garantia, então as leis daquela cidade não tinham validade.

Em termos jurídicos, Shylock questionava a eficácia do direito objetivo, ou seja, do cumprimento da lei, uma vez que via violado seu direito subjetivo como credor. ${ }^{134}$ Mais especificamente, exigia a concretização do direito subjetivo relativo que permitia que exigisse de Antônio a garantia. ${ }^{135} \mathrm{O}$ questionamento da validade das leis e o apontamento para uma questão de insegurança diante do seu cumprimento é o fator decisório que leva o Doge a dizer que finalizará ali a sessão, decidido a entregar a libra de carne a Shylock. No entanto, antes de terminar, o Doge pede para ouvir um jurista que chamara para ponderar sobre o caso. Ao contrário deste, no entanto, chega um jurista mais jovem, supostamente enviado em seu lugar. Este jurista é, na verdade, a esposa de Antônio, Pórcia, disfarçada. ${ }^{136}$

\footnotetext{
132 Ele compara a garantia com a compra de um escravo, pois afirma que na compra de um escravo não se espera do dono que os liberte ou que o case com seus herdeiros. Do mesmo modo, a libra de carne pertence a quem a comprou. Tendo em vista que, à época, a escravidão era bastante comum, lícita e lucrativa (Ainda que Shakespeare tenha escrito a peça em 1596, a disputa entre Shylock e Antônio se passa na Veneza do séc. XIV): "The slaves are ours - so do I answer you: the pound of flesh is mine, which I demand of him, is dearly bought, "tis mine, and I will have it." "O Mercador de Veneza": Ato IV, Cena 1.

133 "If you deny me, fie upon your law! There is no force in the decrees of Venice." "O Mercador de Veneza": Ato IV, Cena I.

134 “O direito subjetivo consiste exatamente nisso: o poder de exigir de outrem a prática de certa conduta; havendo, do outro lado, o dever de alguém seguir essa conduta. Poder e dever, eis o binômio do direito subjetivo". NEVES, José Roberto de Castro. Direito das Obrigações. p. 8.

135 "Finalmente, o outro tipo de direito subjetivo relativo são as obrigações, ou seja, o poder de exigir de uma pessoa que adote certo comportamento em decorrência de um fato específico." Ibid. p. 9.

136 À época, não era permitido que mulheres atuassem em peças teatrais. Até meados de 1660, os papéis femininos das peças teatrais de Veneza eram feitos por homens fantasiados de mulheres. Uma mulher atuando em uma peça seria ultrajante e, miais grotesco ainda, seria uma mulher sustentando perante a Corte. A opinião de que Shylock fora injustiçado também recai sobre o fato de que o julgamento se encontra viciado. Pórcia, travestida do jovem jurista, oculta sua real identidade àqueles sob o julgamento
} 
Primeiro, Pórcia pergunta a Antônio se ele confessa ter feito o acordo. Sendo afirmativa a resposta, dirige-se a Shylock e diz que este deve ser misericordioso. Ela fala sobre a graça do perdão, a benção como atributo que pertence ao divino e a piedade que se curva à justiça. Pode-se perceber aqui o início da estratégia argumentativa de Pórcia. Ela ressalta a ideia do Direito Natural de origem divina, procurando persuadir Shylock e, indiretamente, a própria Corte. ${ }^{137}$ Isso não sensibiliza Shylock.

Nessa hora, Bassânio oferece novamente o dobro da quantia e, se não fosse suficiente, dez vezes a soma. Diz ainda que se Shylock recusasse estaria claro que a maldade se impunha à inocência e era preciso deixar de lado a lei, para realizar um bem maior. Em termos atuais, a lei não deveria prevalecer diante do abuso do direito, ${ }^{138}$ vez que a recusa do credor em receber mais do que a quantia estipulada demonstraria ilegitimidade no interesse e, portanto, não seria o mesmo merecedor de tutela. ${ }^{139}$ Apesar de compreensivos, os argumentos de Bassânio não teriam lugar naquela Corte, pois, àquela época, não eram regras, já que tratavam de princípios não estabelecidos na lei de Veneza.

da corte. Se esta suspeição já não fosse suficiente para viciar a sentença, sua imparcialidade se encontra maculada: O suposto jurista, ao contrário de realizar um juízo de ponderação do caso, almejando a conclusão final, calcada na lei, chega à Corte almejando um só resultado, prescindindo de revestimento legal: Salvar Antônio e lesar Shylock, sem que este receba coisa alguma em contrapartida do empréstimo. A intenção de Pórcia em prejudicar o credor, que evidencia ainda mais sua parcialidade, se manifesta claramente quando Shylock, vendo impossível a concretização do direito de obter a carne, revela que receberá então o dinheiro oferecido anteriormente por Bassânio. Nesse momento Pórcia alega que, tendo previamente recusado o direito de receber o dinheiro, ficaria, pela lei, impedido de reclamálo novamente.

${ }^{137}$ Ditado por uma concepção de superlegalidade, “o direito natural sobrepaira à norma legislativa, e, com este sentido, é universal e é eterno, integrando a normação ética da vida humana, em todos os tempos e em todos os lugares" PEREIRA, Caio Mario da Silva. Instituições de Direito Civil. Vol. I. $24^{\mathrm{a}}$ ed. Rio de Janeiro: Forense, 2011. p. 6.

138 “A liberdade de contratar não é concedida ao homem para que a use contra as instituições e, se ele a emprega nessa obra execrável, desvia-a de sua destinação, exerce anormal e abusivamente o seu direito, porquanto, contendo-se dentro de seus limites objetivos, transcende as fronteiras subjetivas." ANDRADE, Darcy Bessone de Oliveira. Do direito do comerciante à renovação do arrendamento. Minas Genrais: Imprensa Oficial de Minas Gerais, 1940. p. 59.

139،"Expurgada a teoria de todas as suas nuanças e sutilezas, resta o princípio, em virtude do qual o sujeito, que tem o poder de realizar o seu direito, deve ser contido dentro de uma limitação ética, a qual consiste em cobrir todo o exercício que tenha como finalidade exclusiva causar mal a outrem." PEREIRA, Caio Mario da Silva. Instituições de Direito Civil. Vol. I., 2011. p. 564. 
Pórcia, vendo que o caminho vencedor não seria pela misericórdia ou supremacia de algum princípio sobre as leis, escolhe por não seguir o caminho do pleito de Bassânio. ${ }^{140} \mathrm{~A}$ invés disso, percebendo que a argumentação a ser adotada deveria ser puramente jurídica, inicia uma estratégia para livrar Antônio da dívida. Se antes Pórcia começara sua argumentação com base em um direito de origem divina, agora ela procura esteio no Direito Positivo. ${ }^{141}$

A jurista afirma que não haveria força em Veneza que pudesse alterar um decreto estabelecido, pois um precedente como esse deixaria margem para outros abusos da lei e isso não poderia acontecer. De início, parece que ela dá razão a Shylock ${ }^{142}$, mas, ao contrário, prepara o terreno para introduzir sua tese sobre o caso: A garantia concede uma libra de carne, nos termos exatos do contrato, nada a mais e nada a menos. Portanto, a libra de carne era devida, mas somente ela. Deveria então o credor pegar o que the era seu por direito, mas se pagasse mais do que lhe era garantido pelo contrato, ou seja, se derramasse uma só gota de sangue, estaria violando as leis de Veneza e, por essa razão, suas terras e bens seriam confiscados pelo Estado. ${ }^{143}$

Shylock, que por diversas vezes ao longo do julgamento exclamara a sabedoria do jovem jurista, ao pensar que a sentença seria dada em seu favor, expressa nesse momento sua surpresa: “Essa é a lei?", ele pergunta. Percebendo a situação em que se encontra, procura resgatar a oferta dos seis mil ducados, oferecida por Bassânio, que se mostra pronto para entregar o dinheiro. Pórcia

\footnotetext{
${ }^{140}$ Bassânio, apesar de não utilizar a palavra "remissão", procurou convencer Shylock a perdoar a dívida nos moldes do art. 285 do Código Civil de 2002, segundo o qual "A remissão da dívida, aceita pelo devedor, extingue a obrigação"

141 "O direito positivo é o que está em vigor num povo determinado, e compreende toda a disciplina da conduta, abrangendo as leis votadas pelo poder competente, os regulamentos, as disposições normativas de qualquer espécie. Ligado ao conceito de vigência, o direito positivo fixa nesta o fundamento de sua existência" PEREIRA, Caio Mario da Silva. Instituições de Direito Civil. Vol. I. $24^{\mathrm{a}}$ ed. Rio de Janeiro: Forense, 2011. p.5

142 "You must cut this flesh from off his breast. The law allows it, and the court awards it". "O Mercador de Veneza": Ato IV, Cena I. tradução livre: Você deve cortar a carne de seu peito, pois a lei permite e a Corte consente.

${ }^{143}$ De acordo com a lei Veneziana, se um cidadão atentasse contra a vida de outro, seria condenado à morte e seus bens iriam para o Estado.
} 
intervém, afirmando que Shylock teria justiça, pois teria aquilo que fora acordado. ${ }^{144}$ Ela repete que o contrato deve ser cumprido e por isso dinheiro algum pode substituir a libra de carne. Assim, incita o credor a tirá-la, mas lembra que só tem direito a uma libra, nada a mais e nada a menos, sob pena de confisco dos bens.

Shylock se viu em uma situação impossível. Não conseguiria realizar a cobrança da dívida como a lei previa, pois jamais conseguiria tirar a libra de carne sem retirar também um pouco (ou muito) de sangue. Shylock tenta, mais uma vez, receber o dinheiro ${ }^{145}$, objeto principal do contrato, mas Pórcia negalhe a quantia, pois não se tratava do objeto principal e sim da garantia que era devida $^{146}$. Diante da cilada, e após tentar por diversas vezes receber o dinheiro no lugar da carne, Shylock, percebendo que não possuía saída, abre mão da garantia e, se ele achava que o julgamento acabaria ali, estava enganado.

Pórcia, que já conseguira libertar Antônio da dívida, sem permitir que Bassânio despendesse quantia alguma, ainda não estava satisfeita. Nesse momento, temos a fala de Pórcia que expressa bem as artimanhas do Direito e como as minúcias da lei podem pegar, desprevenidos, aqueles que não agem com precaução quanto aos detalhes do ordenamento: "Espera judeu, a lei ainda tem suas garras sobre você." ${ }^{147}$ Ela ressalta que, pela lei de Veneza, se comprovado que um cidadão atenta contra a vida de outro, direta ou indiretamente, seus bens serão confiscados, metade indo para aquele que estava em perigo e a outra metade para o Estado. Enfrentaria ainda o acusado o juízo do Doge sobre sua vida, podendo ser condenado à pena de morte. ${ }^{148}$

\footnotetext{
${ }^{144}$ Afinal, o dinheiro de Bassânio era também seu dinheiro, pois estavam casados. Seu objetivo, portanto, era livrar Antônio da cláusula, mas sem pagar nada a Shylock.

145 "Give me my principal and let me go". "O Mercador de Veneza": Ato IV, Cena I.

146 "Thou shalt have nothing but the forfeiture, to be so taken at any peril, Jew". "O Mercador de Veneza”: Ato IV, Cena I.

147 "Tarry, Jew. The law has another hold on you". "O Mercador de Veneza": Ato IV, Cena I.

148 A drástica mudança de eventos é proposital. Evidente que a atitude de Pórcia era, desde o início, parcial e favorável a Antônio. Por esse motivo, pode-se alegar que o parecer de Pórcia era carregado de ilegalidade decorrente da parcialidade com que atuava. É claro que essa atitude não espanta, pois a
} 
A manifesta atuação parcial de Pórcia retira a atenção para outra ilegalidade: a parcialidade do próprio Doge. Essa, ao contrário daquela, é sutil e por isso passa despercebida. Desde o início, ele possuía posição favorável a Antônio. Ainda que não chegasse ao ponto de afastar a norma sem embasamentos legais, como desejava Bassânio, o Doge não esconde sua preferência pela não concretização da cláusula, mas não encontrava meios legítimos para negar a efetivação da mesma.

É por esse motivo que no momento em que Pórcia encontra um fundamento legalista capaz de livrar Antônio da garantia é imediatamente apoiada pelo Doge. Não foi somente a imparcialidade de Pórcia que condenou Shylock, mas também aquela do próprio Doge. Esta, no entanto, é mais grave do que aquela na medida em que o agente estatal é representante do próprio Estado e sua atuação personifica o agir do próprio Tribunal. ${ }^{149}$

Para grande surpresa, quem concede "misericórdia" ao credor é Antônio, que sugere ao Doge que Shylock perca somente metade dos seus bens, sob a condição de que se converta ao catolicismo. O Doge aceita os termos e assegura que caso sejam descumpridos revogará o perdão que concedeu sobre a vida do credor que, sem escolha, concorda. Ao fim, como previsto por Pórcia, a lei ainda tinha suas garras sobre Shylock e estas são sempre bem afiadas.

\footnotetext{
atuação de Pórcia já tivera início no campo da ilegitimidade no momento em que se travestiu de jurista e atuou na Corte sem possuir autorização legal. Nesse caso, uma atuação imparcial seria contraditória. Não era de se esperar nada a menos do que uma atuação favorável ao devedor. Pórcia teria agido em evidente usurpação da função advocatícia. A atuação do advogado constitui múnus público e assim, estáse diante do exercício ilegal da profissão agravado pela usurpação do múnus público de suma importância para administração da justiça.

149،A imparcialidade, conquanto importantíssima, não é um valor em si própria, mas fatos para o culto de uma fundamental virtude democrática refletida no processo, que é a legalidade. Quer-se o juiz imparcial, para que de tratamento igual aos litigantes ao longo do processo e na decisão da causa." DINAMARCO, Cândido Rangel. Instituições de Direito Processual Civil. $5^{\mathrm{a}}$ ed. São Paulo: Malheiros, 2005. v. 1. p. 220 .
} 


\subsection{A sentença}

Esse não é um final que agrada a todos os estudiosos do Direito. Rudolf Von Ihering opina no sentido de que Shylock fora injustiçado quando, na sentença, o Tribunal de Veneza entendeu por não aplicar a lei. ${ }^{150}$ Para Ihering, quando o Tribunal ponderou que a aplicação pura da lei poderia causar injustiça optou por uma interpretação equitativa. Nesta linha, o resultado seria o desvio do esteio legal, mas com o intuito de obedecer à vontade do legislador, perseguindo o preceito legal e o último objetivo do preceito. No final, escolheuse a limitação da obrigatoriedade da lei, pois se entendeu ser ela menos prejudicial do que a vinculação estrita do juiz à letra da norma. O Doge ponderou os fatos e ajustou os interesses daqueles envolvidos no caso, afastando-se da subsunção formal da lei. ${ }^{151} \mathrm{Ou}$ seja, propositalmente, deixou-se de interpretar o texto a fim de extrair uma regra que se aplicasse ao caso concreto. ${ }^{152}$

Para Ihering, na medida em que a lei reconhece o direito de cortar do corpo de Antônio uma libra de carne, reconhece também i) o direito ao sangue, sem o qual a carne não existe e ii) o direito de cortar menos do que 1 libra de carne. ${ }^{153} \mathrm{O}$ que ocorre na sentença é a negativa de ambos. Não poderia tirar a carne, nem cortar menos do que o estipulado. O mesmo Doge que proclamou o direito passa a frustrá-lo com, segundo Ihering, “uma astúcia tão miserável e tão

\footnotetext{
${ }^{150}$ JHERING, Rudolf Von. A Luta pelo Direito. $17^{\mathrm{a}}$ ed. Tradução de João de Vasconselos. Rio de Janeiro: Revista Forense, 1999. p. xi-xiii.

151 "A subsunção implica apreciar-se como, da generalidade de um dever-ser, de suas implicações gerais, são obtidas as proposições completas desse dever-ser. Ultimar essa operação é aplicar o direito. GRAU, Eros Roberto. Ensaio e Discurso sobre a Interpretação/ Aplicação do Direito. $4^{a}$ ed. São Paulo: Malheiros, 2006. p. 71.

${ }^{152}$ Utilizou-se da suprassunção hegeliana para negar o derrame de sangue: retirando a interpretação extensiva determinou-se o alcance da norma, com a consequente impossibilidade de retirada da carne. Segundo Gauthier, em Lógica hegeliana e formalismo, Diálogo. Revista Canadense de Filosofia n. 5 (set. 1967), p 152, a suprassunção consiste em colocar a parte na ou sob a totalidade. Nega-se e conservase para determinar o que faz parte do todo.

${ }^{153}$ Ihering, Rudolf Von. Op. cit., p. xiii.
} 
nula que nem digna é de uma reputação séria"154.

A artimanha da qual Pórcia fez uso para salvar Bassânio foi o afastamento da hermenêutica normativa e contratual. Seguiu-se à risca a letra do contrato, no sentido literal do que fora pactuado e se deixou de lado a interpretação do acordo firmado, relevando a vontade das partes no momento da firmação do pacto. Aproveitou-se a incompletude ${ }^{155}$ do contrato, que não explicitava por completo os termos da garantia. Assim tornou-se sem sentido a norma que estabelece o seu cumprimento, uma vez que se optou pela interpretação literal e esta impediu a concretização do pacto. ${ }^{156}$

A frustração de Ihering seria facilmente resolvida se fosse reconhecido que, implicitamente, entregar a libra de carne significava também, em consequência, fazer sangrar o devedor. Com o objetivo de afastar a interpretação do contrato que possibilitaria seu cumprimento, foi preciso afastar as cláusulas implícitas. Foi nesse sentido que, séculos após a disputa entre Shylock e

\footnotetext{
${ }^{154}$ Ibid. p. xii.

${ }^{155}$ Por vezes, é possível que as partes propositalmente incluam termos vagos nos contratos celebrados, seja por vantagem econômica, ou por conveniência do acordo. Nesse caso, a incompletude do contrato provavelmente decorreu do esquecimento, por parte de Shylock, que não se preocupou em detalhar os termos da cobrança/retirada da libra de carne. Usualmente, as lacunas são preenchidas com regras que os contraentes teriam acordado se a tivessem preenchido. Dessa forma, a tendência natural e mais óbvia para sanar a lacuna é levar em consideração o que a maioria dos contraentes teria acordado. A proposta de dois estudiosos do campo do Direito e Economia, Robert Gertner e Ian Ayres, em 1989, consistia em penalizar os contratantes que levassem à Corte questões contratuais decorrentes de lacunas. Desse modo, ao invés de preencher a lacuna contratual com a regra que as partes teriam estabelecido quando pactuaram, far-se-ia o contrário: diante da omissão, a Corte estipularia uma regra que as partes não gostariam de incluir no contrato no momento de firmação do pacto: "The "would have wanted' approach to gap filling is a natural outgrowth of the transaction cost explanation of contractual incompleteness." GERTNER, Robert; AYRES, Ian. Filling Gaps in Incomplete Contracts: An Economic Theory of Default Rules. In: POSNER, Richard A.; Parisi, Franceso. Economic Foundations of Private Law. Massachusetts: Edward Elgar, 2002. p. 93. Tradução livre: A teoria do "o que as partes gostariam" para preencher as lacunas é um resultado natural da explicação dos custos contratuais para a incompletude dos contratos.

${ }^{156}$ Ainda que a argumentação exegética baseada na literalidade e na incompletude do contrato tenha funcionado a favor de Pórcia, atualmente, poderia ser substituída pela observação dos deveres anexos ao contrato: boa-fé objetiva, correção, cuidado, cooperação e limitação do exercício de direitos subjetivos como o inciviliter agere, que proíbe comportamentos que violem o princípio da dignidade humana. Relevante será também invocar, segundo Caio Mario, os usos vigentes no lugar da celebração do negócio jurídico, no pressuposto de que as partes, de maneira geral, a eles se submetem implicitamente. Na divergência ao tempo da execução, invoca-los é bom adminículo hermenêutico. PEREIRA, Caio Mario da Silva. Instituições de Direito Civil: Introdução ao Direito Civil. 24ª ed. Rio de Janeiro: Forense, 2011. v. 1. p. 420 .
} 
Antônio, o francês Pothier reuniu princípios de hermenêutica em um tratado de obrigações ${ }^{157}$, fixando regras interpretativas. ${ }^{158}$

Ainda que não se falasse de hermenêutica e técnicas de interpretação na Veneza do século XIV, a opinião de Ihering se constrói de maneira imparcial perante o caso, pois leva em conta o contexto no qual se insere. É importante ter em mente que, na Veneza imaginada por Shakespeare, a liberdade de contratar beirava o absoluto. Preponderava a autonomia da vontade, entendida como o poder do indivíduo em estabelecer livremente determinado negócio jurídico com outro. ${ }^{159}$ Assim, deveria o Estado somente garantir o cumprimento dos acordos entre particulares, pactuados com base na autonomia privada, sem neles interferir. ${ }^{160}$ Impensável seria aplicar, por exemplo, o art. $13^{\circ}$ do Código Civil brasileiro, segundo o qual, "salvo por exigência médica, é defeso o ato de disposição do próprio corpo, quando importar diminuição permanente da integridade física ou contrariar os bons costumes".

Em uma posição desfavorável a Shylock, pode-se extrair da trama a ideia de abuso do direito ${ }^{161}$. Quando Bassânio oferece a Shylock o dobro da quantia

\footnotetext{
${ }^{157}$ Pothier, Robert Joseph. Traité des obligations. Paris, 1942.

${ }^{158}$ Utilizando a $1^{\mathrm{a}}$ e a $9^{\mathrm{a}}$ regra de interpretação de Pothier, a questão da cláusula implícita seria solucionada, uma vez que, segundo estas "Nos contratos, o que mais interessa é a intenção comum das partes e não o sentido literal das palavras" e "Os bens singulares estão englobados, formando uma universalidade". Infelizmente para Shylock, as regras interpretativas de Pothier ainda não existiam na época da peça e o tratado seria publicado somente em 1761.

159 "Detendo-nos um instante mais sobre o elemento vontade, frisamos que o princípio pelo qual se lhe reconhece o poder criador de efeitos jurídicos denomina-se autonomia da vontade, que se enuncia por dizer que o indivíduo é livre de, pela declaração de sua própria vontade, em conformidade com a lei, criar direitos e contrair obrigações. PEREIRA, Caio Mario da Silva. Instituições de Direito Civil. Vol. I. $24^{\mathrm{a}}$ ed. Rio de Janeiro: Forense, 2011. p.400.

${ }^{160} \mathrm{Se}$ se coloca em destaque a autonomia privada, entendida como capacidade dos particulares de dar normas a si próprios numa certa esfera de interesses, e se considerarmos os particulares como constituintes de um ordenamento jurídico menor, absorvido pelo ordenamento estatal, essa vasta fonte de normas jurídicas é concebida de preferência como produtora independente de regras de conduta, que são aceitas pelo Estado. BOBBIO, Norberto. Teoria do Ordenamento Jurídico. Tradução de Maria Celeste C. J. Santos. $6^{\mathrm{a}}$ ed. Brasília: Universidade de Brasília, 1995. p.40.

${ }^{161}$ O Código Civil/2002 prevê que: Art. 187. "Também comete ato ilícito o titular de um direito que, ao exercê-lo, excede manifestamente os limites impostos pelo seu fim econômico ou social, pela boa-fé ou pelos bons costumes". Ainda assim, "Não foi feliz, todavia, o legislador de 2002, ao definir o abuso de direito como espécie de ato ilícito (...) O art. 187 do CC, que define o abuso do direito como ato ilícito deve ser interpretado como uma referência a uma ilicitude lato sensu, no sentido de contrariedade ao direito como um todo, e não como uma identificação entre a
} 
que era devida a ser paga no lugar da libra de carne, o credor ainda assim prefere executar a garantia. $\mathrm{O}$ motivo disto, dado a rivalidade entre o cristão e o judeu, não pode ser outro senão a sede por vingança. Os gestos e palavras de Shylock levam a crer que a justiça que clama perante o Tribunal seria movida não em nome do cumprimento do contrato, e sim pelo desejo de vingança pelos maus tratos que sofrera de Antônio ao longo do tempo.

A busca por vingança fica clara na passagem: "Chamaste-me de cão antes de ter motivo para fazê-lo; porém, visto que sou um cão, tenha cuidado com minhas presas. O doge me concederá justiça"162. Se trazida essa questão para um contexto atual, a lei não poderia servir de instrumento utilizado por motivos fúteis, com a intenção de desvirtuar um direito, ainda que inicialmente legítimo. Isso porque não é protegido um direito que se valha para prejudicar outrem ou para atingir uma finalidade que contraria a lei. ${ }^{163}$ Significa que, embora estivesse o credor no exercício de seu direito subjetivo, não é protegido o ato emulativo, ou seja, aquele que aparentemente exercido dentro da esfera legal, possui o objetivo de causar dano. ${ }^{164}$

Ainda que seja possível reconhecer o abuso e a má-fé na exigência da garantia da libra de carne, essas premissas são utilizadas por Pórcia tão somente depois que Shylock abre mão de qualquer garantia. Ou seja, ela não utiliza o argumento do abuso do direito para salvar Antônio e isto provavelmente ocorre porque se trata de conceito subjetivo, que poderia ou não ser acolhido pelo Doge.

\footnotetext{
etiologia do ato ilícito e a do ato abusivo, que são claramente diversas" TEPEDINO, Gustavo, BARBOSA, Heloísa Helena; MORAES, Maria Celina Bodin de. Código Civil Interpretado: Conforme a Constituição da República. $2^{\mathrm{a}}$ ed. Rio de Janeiro: Renovar, 2011. v. 1. p. 346.

162 "O Mercador de Veneza”: Ato III, Cena III.

163 “O abuso do direito consistirá nesse uso antissocial de um poder jurídico. A parte, vítima do abuso, poderá denunciar e legitimamente resistir à investida de quem se vale de um direito de forma desmesurada". NEVES, José Roberto de Castro. Medida por Medida: O Direito em Shakespeare. $5^{\mathrm{a}}$ ed. Rio de Janeiro: Edições de Janeiro, 2016. p.155.

${ }^{164}$ O caso Bayard (França, 1913) mostra como o titular de direito tem possibilidade de prejudicar outrem, quando o vizinho de um hangar de dirigíveis resolveu levantar em sua propriedade muro divisório com pontas de metal afiadas e com aptidão para estourar os dirigíveis, atrapalhando a atividade do proprietário do prédio vizinho. A corte francesa reconheceu o abuso do direito, determinando a demolição do muro, contribuindo para teoria do abuso do direito.
} 
Pórcia escolhe empregar um método objetivo para evitar a cobrança da garantia, de modo que não haveria meio de contra argumentar sua premissa. O que hoje é chamado de princípio da identidade das prestações proibia, também em Veneza, que Shylock recebesse qualquer coisa diferente da garantia pactuada, impedindo que retirasse de Antônio outra coisa senão a exata uma libra de carne. ${ }^{165}$ Interpretou-se o contrato de maneira estritamente literal, restringindo o objeto da prestação, a fỉm de frustrar a garantia.

A verdade é que Pórcia somente foi vitoriosa em sua argumentação objetiva, pois a lei Veneziana ainda estava distante da vigência do Código Civil Italiano, que seria publicado em 1942 e em cujo capítulo IV, da interpretação do contrato, encontra-se o art. 1.367 com a seguinte leitura: "Nel dubbio, il contratto o le singole clausole devono interpretarsi nel senso in cui possono avere qualche effetto, anziché in quello secondo cui non ne avrebbero alcuno."166 Caso contrário, não seria possível argumentar pela interpretação literal do pactuado e haveria necessidade de recorrer ao abuso do direito, à intenção das partes e à existência de má-fé para sustentar vício no contrato.

Não só Shylock, mas também a própria Corte é vítima da artimanha empregada por Pórcia. O Doge, desde o início do julgamento, mantém-se firme na aplicação do princípio da obrigatoriedade do cumprimento do contrato e da força das obrigações pactuadas. Com isso, em um primeiro momento, impõe, sem ressalvas, a execução do contrato, afirmando que Shylock deve recolher a garantia. Contudo, depois da exposição de Pórcia, o Tribunal toma uma atitude contraditória. Depois de defender o cumprimento estrito do acordo, proíbe o credor de recolher a garantia, calcando-se no princípio da identidade das prestações. A conclusão da Corte permite dizer que, por causa da artimanha de

\footnotetext{
165 “Art. 314 CC/2002: Ainda que a obrigação tenha por objeto prestação divisível, não pode o credor ser obrigado a receber, nem o devedor a pagar, por partes, se assim não se ajustou”.

166 Tradução livre: Na dúvida, o contrato ou as cláusulas individuais devem interpretar-se no sentido em que possam ter qualquer efeito, ao invés de no sentido pelo qual não teriam efeito algum.
} 
Pórcia, não tinha a lei mais uma garra somente sobre Shylock ${ }^{167}$, mas também sobre a própria Corte. É o que leva José Roberto de Castro Neves a sugerir que, ao invés de "O Mercador de Veneza", a peça poderia se chamar de "A Ardilosa de Belmonte". 168

Ao final, é difícil decidir qual personagem agiu de maneira mais capciosa: se Shylock, por querer vingança, usando-se da lei para uma finalidade ilegítima, ou Pórcia que, por querer deixar Shylock sem bens, valeu-se de artifícios tanto ilegais quanto argumentativos para manipular o julgamento. Esse, no entanto, é um fator essencial nesta peça para a aproximação com leitor. Aliás, é este o fator que mais enobrece as obras de Shakespeare e esta, em especial: as personagens são boas e más ao mesmo tempo e é possível que o espectador se veja ora concordando com um, ora concordando com outro, sem saber, ao final, com certeza absoluta, quem tem a razão verdadeira, ou, mais importante, o que seria justo e injusto. ${ }^{169}$

É precisamente a complexidade das personagens o motivo pelo qual permanece a dificuldade em saber se a sentença da Corte foi justa ou injusta. Essa complexidade também estende obstáculos à classificação da peça. Não é possível classificar esta obra facilmente como uma comédia. Quanto ao gênero, há uma intensa troca entre comédia e tragédia e tal metamorfose pode ser percebida desde o início até o fim, conforme a caracterização das personagens vai ficando mais densa. ${ }^{170}$

\footnotetext{
167 "Tarry, Jew. The law has another hold on you" "O Mercador de Veneza”: Ato IV, Cena I.

${ }^{168}$ NEVES, José Roberto de Castro. Medida por Medida: O Direito em Shakespeare. $5^{\mathrm{a}}$ ed. Rio de Janeiro: Edições de Janeiro, 2016. p. 165.

${ }^{169}$ As personagens são más no sentido de terem como objetivo único seus próprios egoísmos e boas porque defendem estes egoísmos, cada qual, baseada no direito que lhes parece ser protegido pela lei. Clamam por nada a mais, nada a menos, do que justiça, na concepção de cada uma delas. São vítimas e, ao mesmo tempo, aproveitadores. Vítimas porque possuem, cada qual, sua própria história, que leva a compreender o motivo pelo qual agem de certa maneira e aproveitadores pois tentam tirar a melhor vantagem possível da situação em que se encontram, ainda que isso prejudique outros.

${ }^{170} \mathrm{O}$ vilão Shylock, por exemplo, avarento no começo, representa o típico vilão cômico, mas logo se torna complexo aos olhos do espectador, e vai ganhando novas feições. Por ser judeu, sofre pela conduta antissemita praticada pelos cristãos e, antes mesmo da sentença dada pelo Tribunal, já havia sido condenado pela própria sociedade e pela História. É por esse motivo que, inicialmente, Shylock era
} 
Tal como permanece a dúvida quanto ao gênero, conserva-se a incerteza quanto à decisão da Corte. A reviravolta de eventos se dá de maneira tão sutil e tão coerente, devido à argumentação astuta de Pórcia que, quando mal se percebe, o autor virou réu, escapou da forca por "misericórdia" do devedor e se viu prestes a perder todos os seus bens. A demanda do réu contra o autor na mesma lide tomou proporções extremamente desfavoráveis para o credor. ${ }^{171}$ Longe de mera coincidência, o título "Veneza: Uma Corte de justiça" é certamente inclinado a uma reflexão sobre "a justiça” ali empregada. Afinal, a problemática central gira em torno da sentença ideal para o caso. O Doge, ignorando os pleitos de Bassânio para que se afaste a lei em nome do bem maior, não se apega ao que seria justo ou injusto subjetivamente. Ele se atenta nos limites estritos lei, declarando válida a cláusula penal acessória, mas impossibilitando seu recolhimento pelo credor, uma vez que não seria possível retirar a carne sem retirar o sangue. ${ }^{172}$

A Justiça, para o Doge, estava em seguir a letra da lei. Para Shylock, era a entrega da garantia, uma vez que, implicitamente, estaria estipulada a retirada de sangue junto à carne, já que esta sem aquela, tornava a garantia incobrável. Para Bassânio, justiça seria realizar o pagamento em dinheiro, uma vez que a retirada da libra de carne ameaçaria a integridade física do devedor, pedindo à Corte que, somente uma única vez, afasta-se a aplicação da lei, fazendo um

\footnotetext{
representado como uma figura cômica, mas na metade do séc. XVIII transformou-se em vilão. Depois, foi visto como vítima da tragédia, sobretudo durante a Alemanha nazista, onde o livro entrou para a lista negra e foi confiscado das livrarias.

${ }^{171}$ A reconvenção é demanda do réu contra o autor no mesmo processo em que está sendo demandado. É o contra-ataque que enseja o processamento simultâneo da ação principal e da ação reconvencional, a fim de que o juiz resolva as duas lides na mesma sentença. DIDIER Jr., Fredie. Curso de Direito Processual Civil. 13 ${ }^{\mathrm{a}}$ ed. Salvador: JusPODIVM, 2011. v. 1. p. 516.

${ }^{172} \mathrm{O}$ Doge certamente realizou um prévio juízo de proporcionalidade e percebeu que se seguisse à risca a letra da lei e desse razão à Pórcia tornaria impossível a cobrança da garantia, o que trouxe insegurança jurídica sobre os decretos de Veneza. Vale lembrar as palavras de Eros Grau: "Por isso tenho medo dos juízes e dos tribunais que praticam esse inusitado controle de proporcionalidade e de razoabilidade das leis, legando-me incerteza e insegurança jurídica". GRAU, Eros Roberto. Por que tenho medo dos juízes: A interpretação/aplicação do direito e os princípios. $6^{\text {a }}$ ed. São Paulo: Malheiros. 2013. p. 24.
} 
pequeno mal, em nome de um bem maior. ${ }^{173}$ Para Pórcia, justiça seria salvar Antônio, sem diminuir a fortuna de Bassânio, que também era sua, e ainda mais, penalizar Shylock severamente. O Doge, ao optar por empregar a justiça por meio da legalidade extremista, seguindo à risca a letra da lei, acabou por também entregar à Pórcia aquilo que pretendia.

A expressão "Corte de Justiça" se mostra como uma caricatura da postura imprecisa dos Tribunais. A imprecisão provém da oscilação na postura da Corte, que inicia a sessão com um posicionamento e termina com outro inverso. No início do julgamento, o Doge lamenta por Antônio e fica claro, para todos ali presentes, que a cláusula é válida e sobre isso não há discussão. Essa "verdade" faz com que o julgamento tenda pela retirada da carne, até o momento que Pórcia toma a palavra. O Doge percebe que poderia chegar ao resultado que achava mais justo (a não retirada da carne), escondendo sua verdadeira intenção por trás do discurso ardiloso da jurista.

A reviravolta de eventos pela argumentação bem elaborada da farsante jurista revela que a Corte é não somente flexível, sendo possível realizar a ponderação das normas sobre o caso concreto, mas também maleável: mostrouse suscetível de manipulação por um discurso jurídico astuto e artificioso, colocando em situação duvidosa a tão almejada "justiça". Pode-se concluir que Shylock tinha parcialmente razão quando afirmou que não havia vigor nos decretos de Veneza. Parcialmente porque o que faltava, na verdade, era segurança jurídica.

\footnotetext{
173 "To do a great thing, do a little wrong. And curb this cruel devil of his will." "O Mercador de Veneza": Ato IV, Cena I. Tradução livre: Para realizar algo muito bom, faça algo um pouco ruim e livrai esse demônio cruel da sua vontade.
} 


\section{CAPÍTULO 3 - DIREITO, ECONOMIA E PACTA SUNT SERVANDA}

\subsection{Antônio, Shylock e o direito obrigacional}

A maioria dos manuais jurídicos optam pela divisão didática e facilitadora dos direitos inerentes às relações do ser humano em valores da personalidade e direitos patrimoniais (direitos reais e obrigacionais). Segundo Álvaro Villaça Azevedo ${ }^{174}$, esta catalogação se dá da seguinte maneira: os primeiros, sistematizados entre os art. 11 ao 21 do Código Civil, dizem respeito à vida, liberdade, decoro, nome, disposição do corpo, entre outros intrínsecos à pessoa, com fundamento principal na dignidade da pessoa humana. Os direitos patrimoniais, por sua vez, são exercidos fora da intimidade da pessoa humana, sobre bens jurídicos exteriores de valor econômico. Dentro deste, estão os direitos reais, que sujeitam a coisa à vontade do titular e também os obrigacionais, que dependem do cumprimento de uma prestação, vinculada a uma relação jurídica obrigacional.

Esta última ramificação do Direito Patrimonial tem como fundamento histórico primordial a autonomia da vontade. Assim, o ordenamento fixa teorias gerais e deixa à vontade dos indivíduos uma brecha para atuação conforme desejarem, limitados hoje pelos princípios gerais de direito, pela ordem pública, bons costumes, probidade, boa-fé, função social do contrato e dignidade da pessoa humana. Estes últimos princípios conformadores da "autonomia da

\footnotetext{
${ }^{174}$ AZEVEDO, Álvaro Vilaça. Teoria Geral das Obrigações e Responsabilidade Civil. 12a ed. Atlas. São Paulo. 2011. p. 2.
} 
vontade" aplicada à obrigação contratual surgem com a nova Ordem Constitucional de 1988. Antes, o que regia o Direito Obrigacional junto à “autonomia da vontade" eram os dogmas da relatividade dos efeitos do contrato e intangibilidade do seu conteúdo, o que contribuiu para a fortificação da obrigatoriedade do pacto e da construção do postulado pacta sunt servanda, ou seja, o contrato seria como lei entre as partes. ${ }^{175}$

Ao longo de toda a peça do Bardo, vários são os indícios de que a relação entre Shylock e Antônio ${ }^{176}$ se fundamenta no princípio da força obrigatória dos contratos, acima de qualquer outro. ${ }^{177}$ Ambos são obrigados, nos limites da lei, àquilo que acordaram no momento da firmação acessório da fiança, ou seja, à

175 "Compreende-se a importância sistêmica da força vinculante dos contratos, pois, na sua ausência, seria impossível a coibição do descumprimento da palavra empenhada e, consequentemente, o desestímulo de comportamentos oportunistas prejudiciais ao tráfico. Assim, o princípio do pacta sunt servanda mostra-se necessário ao giro mercantil na medida em que freia o natural oportunismo dos agentes econômicos" FORGIONI, Paula A. Teoria geral dos contratos empresariais. $2^{\circ}$ ed. São Paulo: Revista dos Tribunais, 2010.p. 81

${ }^{176}$ Segundo Paula Forgioni, são ditos contratos mercantis aqueles nos quais as partes têm no lucro o escopo da sua atividade. Ibid. p. 38. Para Fran Martins, obrigação comercial é a obrigação que resulta de um ato de natureza comercial. MARTINS, Fran. Contratos e obrigações comerciais. $14^{\mathrm{a}}$ ed. Rio de Janeiro: Forense, 1998. p. 9. A relação entre Antônio e Shylock se assemelha às relações entre empresários dos dias de hoje. Shylock é o típico mercador que empresta dinheiro com cobrança de juros e Antônio o usual comerciante à espera de seus prósperos navios. Em relação ao contrato de fiança, Carlos Alberto Bittar explica: "as garantias remontam ao direito antigo, estando já estruturadas à época clássica e ingressando depois nas codificações. Mas a fiança comercial apresenta certas peculiaridades em relação à fiança civil, sendo identificada a primeira pela inserção em atividade considerada como tal causa comercial e condição do afiançado como empresário comercial são os elementos que, em concreto, a qualificam." BITTAR, Carlos Alberto. Contratos comerciais. $6^{\mathrm{a}}$ ed. Rio de Janeiro: Forense Universitária, 2010. p. 97. Para o direito pós-moderno, pode o empréstimo concedido à Bassânio por Antônio não constituir elemento suficiente para caracterizar uma fiança comercial com Shylock, visto que o objetivo do afiançado era cortejar uma donzela. Engana-se o leitor que não enxerga na atitude de Bassânio a mentalidade empreendedora burguesa. Para a burguesia veneziana do século XIV a relação matrimonial poderia ser tipicamente comercial na medida em que o cortejo se voltava para a moça, mas almejada sua herança. Diversos foram os pretendentes que tentaram se casar com Pórcia. Nenhum passou no teste até Bassânio chegar e ela colocava defeito em todos da maneira que se põe defeito nos objetos de negociações mercantis. É ingênuo pensar que a fiança garantia uma relação de amor, quando na verdade garantia um negócio da qual ambas as partes pretendiam tirar vantagens econômicas: Bassânio precisava de dinheiro e Pórcia necessitava do matrimonio para poder mexer em sua fortuna sob a supervisão do marido.

${ }^{177}$ O Doge de Veneza não pediria a Shylock que demonstrasse clemência desde o início do julgamento se não fosse clara a força obrigatória das manifestações de vontade no momento do pacto. Tampouco se poria a repetir Shylock que queria a garantia que lhe era devida, incansáveis vezes perante a Corte, se não fosse supremo o postulado da força obrigatória. 
manifestação de vontade. ${ }^{178}$ Diversos são os momentos em que se ressalta a vinculação das partes ao contrato como se este fizesse lei entre o credor e o fiador, aproximando-se da imutabilidade.

A expressão "pacta sunt servanda", que significa "os pactos devem ser cumpridos", é o foco jurídico central da peça, uma vez a problemática principal é criada pela força deste postulado, possuindo o julgamento somente duas saídas: mitigar a força que vincula as partes do contrato por algum outro argumento jurídico, desobrigando Antônio a pagar a garantia ou permitir que Shylock retire a carne do cristão, sob o fundamento de que o contrato faz lei entre as partes e que o acordo deve ser cumprido tal como estipulado no momento do pacto. Ao final, a Corte decide pela primeira opção. ${ }^{179}$

A saída vitoriosa arquitetada por Pórcia se baseia na mitigação do postulado da força obrigatória, graças a argumentos hermenêuticos do contrato. Diante do contexto da peça, esta parece ser a única saída que permitiria Antônio a manter a libra de carne em seu corpo, uma vez que o desenvolvimento da trama leva a entender que a parte do corpo como objeto pactuado é claramente permito entre contratantes. Sendo assim, na situação imaginada por Shakespeare ${ }^{180}$,

\footnotetext{
${ }^{178}$ As definições de negócio jurídico pela gênese ou voluntaristas, fundamentadas na manifestação da vontade, são, sem dúvida, dominantes na doutrina brasileira. A força obrigacional oriunda da vontade particular, bem como as definições de negócio jurídico como ato de vontade são, segundo Antônio Junqueira "as mais antigas na ordem história e talvez se possa dizer que, até hoje, mesmo na doutrina estrangeira, são elas ainda as mais comuns." AZEVEDO, Antônio Junqueira de. Negócio Jurídico: existência, validade e eficácia $4^{\circ}$ ed. Saraiva, 2002. p. 5.

${ }^{179}$ Fica a dúvida quanto ao fato de que se o elemento empresário fosse trazido à tona, a decisão teria sido diferente. Sendo ambas as partes comerciantes bem-sucedidos no exercício de suas atividades profissionais (empréstimo), haveria alguma diferença na decisão de uma Corte contemporânea? A resposta está no paradoxo da liberdade contratual. Fernando Araújo explica que a lógica econômica parece atingir sua perfeição máxima ao invocar o regime contratual com normas imperativas para a preservação da liberdade econômica. No entanto, a liberdade pode ser usada para comprometer ou destruir os seus próprios fundamentos: "Há que protegê-la contra ela mesma, ou melhor contra o seu uso abusivo. E assim, depois de uma tradição de apoio incondicionado à liberdade contratual, passou-se a uma fase de desconfiança perante os arranjos contratuais que podiam converter-se em veículos de desequilíbrio e de predação." ARAÚJO, Fernando. Teoria Econômica do Contrato. Coimbra: Almedina, 2007. p. 434

${ }^{180}$ Não se sabe ao certo se Shakespeare conheceu Veneza em algum ponto da sua vida, ou se tinha ciência das leis venezianas, uma vez que a distância entre as cidades era um empecilho à divulgação de informações. Desse modo, a análise jurídica da peça deve se basear somente nas informações fornecidas pelo autor, ao invés de buscar fundamento no ordenamento jurídico vigente à época.
} 
argumentos como dignidade da pessoa humana, função social do contrato e boafé não eram ferramentas valorizadas pelo ordenamento jurídico daquela época ou que pudessem livrar Antônio da garantia pactuada, sob o argumento de ser inválida diante de princípios sociais. ${ }^{181}$

Advogar em nome de Antônio sob as regras do ordenamento jurídico vigente seguramente consistiria em trazer à tona os novos princípios. Esse é o motivo pelo qual este capítulo se dedicará a primeiramente a reconstruir o julgamento em "O Mercador de Veneza" sob a luz do ordenamento atual, contudo sem fazer uso dos princípios de cunho social. Serão utilizados argumentos de cunho econômico, prático e patrimonial para provar que a evolução do Direito Obrigacional se constrói e se desenvolve, não somente por meio dos aspectos sociais, mas também dos aspectos econômicos e que também são estes, em parte, os responsáveis pela mitigação do postulado pacta sunt servanda.

\subsection{Direito das obrigações e mutabilidade}

Para compreender o que influencia e alimenta o Direito Obrigacional, é necessário primeiramente buscar uma definição. A descrição de Direito das Obrigações pelos manuais de Direito envolve, obrigatoriamente, sujeitos passivos e ativos, normas legais e o dever pactuado. Nas palavras de Pablo Gagliano e Rodolfo Pamplona Filho "trata-se do conjunto de normas (regras e princípios jurídicos) reguladoras das relações patrimoniais entre um credor (sujeito ativo) e um devedor (sujeito passivo) a quem incumbe o dever de

\footnotetext{
181 Tais princípios claramente funcionariam a favor de Antônio se o julgamento ocorresse à luz do ordenamento jurídico vigente, sob a perspectiva na nova ordem do direito civil constitucional pós 1988 . Atualmente, perante o ordenamento brasileiro, não seria preciso fazer uso da ferramenta hermenêutica para driblar o postulado da força obrigatória daquele contrato, uma vez que é possível mitigá-lo com os novos princípios constitucionais aplicados ao direito contratual.
} 
cumprir, espontânea ou coativamente, uma prestação de dar, fazer ou não fazer". ${ }^{182}$

A obrigação contraída por duas ou mais partes pode ser vista como um liame economicamente funcional, uma vez que por meio dela "se efetiva a circulação de bens e direitos no comércio jurídico". ${ }^{183}$ Ainda mais, pode-se afirmar que a relação jurídica onde o dever possui natureza econômica consiste em uma obrigação na qual o credor pode exigir do devedor a prestação devida. Isso significa que a dinâmica da relação obrigacional se desenvolve em um ciclo, até se encerrar com o pagamento. As regras que determinam o desenvolvimento deste ciclo sofreram e continuam sofrendo mutações ao longo do tempo.

Primeiramente, é preciso esclarecer que Direito das Obrigações diz respeito a aspectos econômicos e sociais simultaneamente na medida em que as circunstâncias negociais somente são possíveis através da interação humana. A consequência desta combinação é o eterno dinamismo, ainda que lento, do Direito Obrigacional. Uma vez em que as relações entre os homens vão sendo moldadas através de princípios que se alteram ao longo da História, também se modificam os valores e hábitos sociais aplicados as relações negociais. Nas palavras de Álvaro Villaça Azevedo: “O Direito das Obrigações é o que menos se torna sensível às mutações sociais. Entretanto, não se pode dizer que seja ele imutável, pois o Direito não deixa de ser a própria vida social normatizada, regulamentada pelas normas". ${ }^{184}$

Essa dinâmica pode ser percebida desde o início da História do Direito. Se era comum no Direito Romano que o credor pudesse dispor do corpo do devedor inadimplente ${ }^{185}$, hoje a obrigação não incide diretamente sobre a pessoa

\footnotetext{
182 GAGLIANO, Pablo Stolze; PAMPLONA Filho, Rodolfo, Novo curso de Direito Civil, 2017, $18^{\mathrm{a}}$ ed. Rio de Janeiro: Saraiva, 2017. p. 46.

${ }^{183}$ Ibid. p. 317.

${ }^{184}$ AZEVEDO, Álvaro Vilaça. Op. cit., p. 6.

185 "Depois do terceiro dia de feira, será permitido dividir o corpo do devedor em tantos pedaços quanto forem os credores, não importando cortar mais ou menos; se os credores preferirem poderão vender o devedor a um estrangeiro". Tábua Terceira, Lei das XII Tábuas.
} 
do devedor, mas sim sobre seu patrimônio. ${ }^{186}$ A primeira codificação bemsucedida a expressar o novo ponto de vista foi objeto de consolidação pelo Código Napoleônico em 1804, uma vez que este determinava serem os bens do devedor a garantia comum dos credores. ${ }^{187}$

Por ter sido compilado após a Revolução Francesa, é compreensível que haja imediata associação entre as regras compiladas no novo Código Civil francês e os princípios revolucionários que culminaram entre 1789 e 1799: Igualdade, Liberdade e Fraternidade. No entanto, não é plausível afirmar que foi com o único propósito de proteção do homem que se deslocou a garantia da pessoa do devedor para o seu patrimônio, nem que o Direito Obrigacional é hoje unicamente regido por princípios sociais como dignidade da pessoa humana e função social do contrato.

Ainda que a aplicação das novas principiologias pós-modernas aos negócios jurídicos decorra da alteração dos pilares que regem a relação entre os homens e que impactam diretamente nos instrumentos utilizados para reger tais relações, os novos princípios sociais não substituem por completo os dogmas que regiam as obrigações até então. Assim, a mudança drástica de centralização do patrimônio do devedor possui duas razões igualmente importantes: a mais evidente é a valorização da dignidade da pessoa humana e a menos óbvia consiste na concessão de um maior dinamismo dos objetos comercializados no âmbito jurídico ${ }^{188}$, uma vez que os bens de um indivíduo são "mais valiosos" para o comércio jurídico do que seus corpos. ${ }^{189}$

\footnotetext{
${ }^{186}$ Ressalta-se que a exceção é a prisão civil do devedor de alimentos na forma do $528 \S 3^{\circ}$ do CPC. Nesse caso, a ponderação dos princípios pós-modernos teve como resultado priorizar a dignidade do alimentado em detrimento da liberdade daquele que tem o dever de prover os alimentos.

${ }^{187}$ Art. 2.093 "les biens du débiteur sont le gage commun de ses créanciers".

${ }^{188}$ Em relação à obrigação comercial, Fran Martins explica: "Sendo o Direito Comercial um Direito dinâmico, para bem atender às necessidades do comércio, esse fato se reflete nos contratos comerciais, que são os principais atos realizados pelos comerciantes no exercício de sua profissão. E esses atos, por que razão, requerem regras que muitas vezes divergem das estabelecidas na lei civil”. MARTINS, Fran. Contratos e obrigações comerciais. 14 a ed. Rio de Janeiro: Forense, 1998. p. 62.

189 "Tal modificação valoriza a dignidade humana ao mesmo tempo em que retira a importância central da obrigação do indivíduo no polo passivo, o que possibilitou, inclusive, a transmissibilidade das
} 
As mudanças de perspectiva sobre as relações negociais de cunho patrimonial passam a ser fundamentadas não somente sobre os ideais sociais, mas também sobre pilares econômicos. É este aspecto econômico que justifica a permanência do dogma da força obrigatória do pacto, ainda que o postulado pacta sunt servanda venha sofrer modificações frente a novas mudanças, novos princípios e hábitos sociais. A evolução do Direto Obrigacional é, portanto, o resultado da clara interseção entre os valores econômicos e sociais, sem que um seja mais importante do que o outro.

\subsection{Liberalismo econômico e Vínculo obrigacional}

Tal como expõe Álvaro Vilaça Azevedo, "a evolução do Direito das Obrigações está presa ao elemento econômico e se faz muito lentamente". ${ }^{190}$ Assim, a primeira grande mudança da força obrigacional do contrato veio com o triunfo do liberalismo econômico no séc. XIX, quando o formalismo contratual foi ofuscado pelo consensualismo, ou seja, deu-se máxima importância à manifestação da vontade, em detrimento de uma forma específica essencial à validade do contrato. Teresa Negreiros ressalta que,

"O liberalismo econômico, também ele uma doutrina desenvolvida no século XVIII, inspira-se na valorização da vontade individual como elemento de garantia do equilíbrio econômico e da prosperidade. $\mathrm{Na}$ base desta doutrina econômica está a concepção de que a satisfação dos interesses individuais dá lugar, como consequência inexorável, à satisfação do interesse geral, que nada mais é do que a soma dos interesses individuais"191

O que fortalecia o vínculo obrigacional entre contratantes, portanto, eram os princípios que regiam suas ações no momento da declaração da vontade.

\footnotetext{
obrigações, não admitida entre os romanos.” GAGLIANO, Pablo Stolze; PAMPLONA Filho, Rodolfo. Op. cit., p. 47.

${ }^{190}$ AZEVEDO, Álvaro Vilaça. Op. cit., p. 7.

${ }^{191}$ NEGREIROS, Teresa. Op. cit., p 26.
} 
Assim sendo, o respeito à vontade manifestada no ato da firmação do contrato faria justiça entre as partes. ${ }^{192}$

Em meados do séc. XX, o postulado "pacta sunt servanda" e sua fonte principiológica de resguardo à declaração de vontade e consensualismo passa a ser mais profundamente analisado pelo estudo da interseção de direito e economia. Ainda que as primeiras análises da Escola "Law and Economics"193 tenham recaído sobre áreas relacionados a tributos, empresas e regulação antitruste ou de mercado, a partir de 1960, a incidência da visão econômica sobre o Direito passa a iluminar outras áreas legais, incluindo responsabilidade civil, propriedade e contratos. ${ }^{194}$

A obrigação contratual, por sua vez, surgiu como uma aplicação natural dos aspectos econômicos do Direito, uma vez que as leis contratuais determinam regras facilitadoras das transações no mercado e delimitam legalmente a atuação daqueles que desejam realizar negociações econômicas. Richard Posner afirma, nesta linha, que:

"A economia provê o rigor analítico necessário para o estudo do extenso corpo legal de regras presentes no sistema legal da sociedade moderna. Essa revolução intelectual veio em um momento fortuito, quando a Academia legal procurava por uma ferramenta capaz de permitir uma apreciação crítica da lei, ao invés de simplesmente fortalecer as consistências dogmáticas no sistema." ${ }^{195}$

A aplicação da visão econômica no Direito Contratual se dispõe a

\footnotetext{
192 O postulado "Qui dit contractuel dit juste" é atribuído ao filósofo Alfred Fouillée, inspirado em Kant e na teoria da autonomia da vontade.

${ }^{193}$ Segundo Richard Posner e Francesco Parasi, ainda que antecedentes notáveis sejam atribuídos a Adam Smith e a discussão dos efeitos econômicos na legislação e à teoria de Jeremy Bentham sobre legislação e utilitarismo, foi somente no séc. XX com o trabalho de autores como Henry Simon, Aaron Director, Henry Manne, George Stigler, Armen Alchian, Gordon Tullock e outros que a ligação entre o direito e a econômica se tornou objeto de estudo verdadeiramente perseguido pelos acadêmicos. POSNER, Richard A.; PARISI, Francesco. Economic Foundations of Private Law. Massachusetts: Edward Elgar, 2002. p. ix.

194 Ibid. p. ix.

195 "Economics provided the analytical rigor necessary for the study of the vast body of legal rules present in a modern legal system. This intellectual Revolution came at a fortuitous moment, when the legal academia was actively searching for a tool that would permit a critical appraisal of the law, rather than merely strengthening the dogmatic consistencies in the system." Ibid. p. ix.
} 
explorar, dentre outros ${ }^{196}$, os elementos que tornam o contrato obrigatório, bem como as questões do inadimplemento. Em relação à exigibilidade dos termos contratuais, já no séc. XX a Escola do "Direito e Economia" se deparou com uma questão imediata: a exigibilidade estrita do contrato poderia desencorajar contratos futuros e, por outro lado, a falta de obrigatoriedade e não execução reduziria a confiabilidade e segurança dos contratantes.

Se um contrato realizado entre partes perfeitamente capazes, com objeto lícito, possível e determinado pode ser facilmente descumprido ou alterado sem maiores consequências ao usurpador não há confiabilidade no ordenamento jurídico ${ }^{197}$. Por outro lado, se o liame obrigacional for tão rígido a ponto de fazer prevalecer um pacto impossível ou que vá de encontro com o próprio ordenamento jurídico e seus princípios, a lei contratual se torna um empecilho ao invés de um mecanismo facilitador e confiável para reger relações pessoais.

Para garantir a força da obrigação contratual e encorajar o cumprimento do pacto, de maneira que o contrato constitua um instrumento confiável entre partes, a lei deve afastar interesses egoístas dos contratantes, levando os indivíduos a considerar os efeitos externos de suas decisões. Para tanto, foram estudados os mecanismos de incentivos ao adimplemento, bem como sanções em caso de não execução, sempre buscando concretizar a vontade manifestada no momento de firmação do contrato. O que se buscava, portanto, eram maneiras de se manter fiel à manifestação de vontade externada no momento do pacto, ou seja, a manutenção do vínculo jurídico entre credor e devedor tal qual exteriorizado na ocasião de manifestação das vontades.

O vínculo entre credor e devedor não somente inicia o ciclo obrigacional,

\footnotetext{
196 “A análise econômica do contrato pretende ser complementar à análise jurídica, fazendo ressaltar o escopo utilitário que preside, quase invariavelmente, à deliberação de contratar, e fazendo recair uma especial atenção nos efeitos geradores de riqueza, que podem associar-se àquele acordo de coordenação de condutas, efeitos que o transformam em veículo de consumação e permuta de utilidades." ARAÚJO, Fernando. Teoria Econômica do Contrato. Coimbra: Almedina, 2007. p. 14.

${ }^{197}$ Bem como expressou Shylock diante da possibilidade de não exigibilidade dos termos contratuais, se a lei não for cumprida e sua aplicação pela Corte for discricionária "não há força nos decretos de Veneza".
} 
como também se mantem durante todo o pacto, até o final, sendo a corrente que une os contratantes em suas palavras, promessas e dívidas. O início deste ciclo obrigacional pode se dar de maneiras distintas, uma vez que três podem ser as fontes dessa obrigação, segundo o ordenamento jurídico brasileiro: o ato unilateral, o ato ilícito ou o contrato. Esta última será o objeto de análise deste capítulo levando em consideração que, caso não ocorra o cumprimento, o devedor passa a ser responsável pelo inadimplemento contratual. ${ }^{198}$

Os elementos que integram a relação jurídica deste ciclo obrigacional são: pluralidade de sujeitos, devedor e credor, o vínculo que os obriga mutuamente e a prestação objeto do pacto. Este segundo é o que mais importa para a análise da força obrigatória do cumprimento do contrato. $\mathrm{O}$ vínculo jurídico entre sujeito ativo e passivo é chamado de elemento abstrato ou espiritual da obrigação, por meio do qual fica o devedor obrigado a cumprir a prestação oriunda do fato jurídico. Para Álvaro Vilaça Azevedo,

"O elemento espiritual da obrigação é o vínculo jurídico, o liame, que liga os sujeitos, ativo e passivo, que participam da mesma, possibilitando àquele exigir deste o objeto da prestação. É um elemento imaterial, que retrata a coercibilidade, a juridicidade, da relação jurídica obrigacional. Ele garante, em qualquer espécie de obrigação, o seu cumprimento, porque, se este não se realizar espontaneamente, realizar-se-á coercitivamente, com o emprego da força, que o Estado coloca à disposição do credor, por intermédio do Poder Judiciário." 199

É possível, no entanto, que ocorra o inadimplemento, seja ele culposo, fortuito ou relativo. Nesta hipótese, está-se diante do rompimento ou enfraquecimento do vínculo formado entre as partes contratantes na hora da firmação do pacto. Para que as normas legais que regem as obrigações não se mostrem frouxas em sua aplicação, é preciso que sejam dotadas de força

\footnotetext{
${ }^{198}$ Importante ressaltar a diferença entre os institutos da obrigação e da responsabilidade uma vez que a segunda ocorre quando a primeira não é cumprida, significando que "se a relação jurídica originária não for cumprida, ou seja, se o devedor, por ato espontâneo, não efetivar o pagamento da prestação jurídica a que se obrigou junto ao credor, surge, em razão desse descumprimento, desse inadimplemento obrigacional, a responsabilidade, com todas as suas implicações" AZEVEDO, Álvaro Vilaça. Op. cit., p.19.

${ }^{199}$ Ibid. p.16.
} 
normativa e sejam aplicadas no caso concreto, frente ao descumprimento. Por isto, cada ordenamento deve ser responsável pela criação de ferramentas e mecanismos capazes de impor aos contratantes o cumprimento das promessas feitas.

\subsection{Inadimplemento, indenização e execução forçada}

É precisamente o vínculo existente entre credor e devedor que faz com que o inadimplemento resulte na responsabilidade do devedor em compensar o credor que fica sem o pagamento ou sem o receber no tempo e modo convencionado, seja por culpa daquele, ou porque o mesmo assumiu a responsabilidade pelos prejuízos. Por isso, pode-se concluir que este vínculo abstrato é a essência da força obrigacional na qual se funda o pacto. Desse modo, a compensação pela ruptura do mesmo tem como objetivo compensar a parte prejudicada para que sua situação após o descumprimento seja economicamente semelhante àquela em que se encontraria diante do adimplemento.

Inadimple culposamente o devedor que age com negligência ou mesmo dolo e esta atitude impossibilita o cumprimento da obrigação pactuada. Neste caso, deverá o mesmo indenizar o credor em perdas e danos. ${ }^{200} \mathrm{O}$ inadimplemento fortuito, por sua vez, caracteriza uma inexecução que não pode ser imputada ao devedor, a não ser que este tenha assumido os riscos causados por caso fortuito ou força maior, assumindo os prejuízos. ${ }^{201}$ Já o inadimplemento relativo acontece quando a obrigação não for cumprida no tempo, lugar e forma convencionados previamente. ${ }^{202}$

\footnotetext{
${ }^{200}$ Art. 389 CC/2002: "Não cumprida a obrigação, responde o devedor por perdas e danos, mais juros e atualização monetária segundo índices oficiais regularmente estabelecidos, e honorários de advogado." 201 Art. 393 CC/2002: "O devedor não responde pelos prejuízos resultantes de caso fortuito ou força maior, se expressamente não se houver por eles responsabilizado. Parágrafo único. O caso fortuito ou de força maior verifica-se no fato necessário, cujos efeitos não era possível evitar ou impedir."

202 Art. 394 CC/2002: "Considera-se em mora o devedor que não efetuar o pagamento e o credor que não quiser recebê-lo no tempo, lugar e forma que a lei ou a convenção estabelecer."
} 
Descumprido o contrato, resta determinar os remédios legais para sanar o inadimplemento. Se a obrigação é o pagamento em pecúnia, não há maiores discussões para sanar o inadimplemento absoluto ou a mora, na medida em que se fará por meio da compensação. Por outro lado, no caso de obrigações cuja prestação consiste em fazer ou não fazer ou entrega de coisa, dois são os métodos possíveis para solucionar a não execução: perdas e danos ou execução forçada. O primeiro é o preferido pela tradição Anglo-Americana. Nesta tradição, portanto, a execução específica se mostra como uma medida excepcional, utilizada de maneira discricionária pelos tribunais e preterida em face da compensação por perdas e danos. ${ }^{203}$

$\mathrm{Na}$ medida em que a força obrigacional desprendeu-se da seara pessoal do devedor e passou a recair sobre o patrimônio, isso poderia acarretar no enfraquecimento da imposição da execução forçada, dando lugar a um ordenamento contratual baseado na doutrina das perdas e danos. O resultado seria a intangibilidade da vontade e da liberdade humana como valor maior e a conversão de todas as obrigações inadimplidas, inclusive de fazer e não fazer em indenizações. Nesta linha,

"A visão tradicional do direito das obrigações, pelo seu cunho intrinsecamente patrimonialista, sempre defendeu que seria uma violência à liberdade individual da pessoa a prestação coercitiva de condutas, ainda que decorrentes de disposições legais e contratuais." 204

Há quem defenda, no direito estrangeiro, que a execução forçada deveria ser tão valorizada e repercutida quanto o pagamento de perdas e danos, uma vez que se propõe como o método mais preciso de atingir o objetivo de compensar uma promessa que foi rompida de maneira tão satisfatória quanto seria se o

\footnotetext{
${ }^{203}$ POSNER, Richard A.; PARASI, Francesco. Op. cit., p. xxii.

${ }^{204}$ GAGLIANO, Pablo Stolze; PAMPLONA Filho, Rodolfo. Op. cit., p. 96.
} 
contrato houvesse sido cumprido. ${ }^{205} \mathrm{Na}$ mesma linha, Pablo Gagliano e Rodolfo Pamplona Filho também afirmam ser inaceitável que a resolução em perdas e danos seja a única consequência para o descumprimento de obrigações de dar, fazer e não fazer. ${ }^{206}$

Ao contrário da tradição Anglo-Americana, o ordenamento brasileiro não alimentou a incoercibilidade da vontade humana a tal ponto que tenha virado um dogma inafastável. Relativizou-se o dogma segundo o qual "ninguém pode ser diretamente coagido a praticar ato a que se obrigara" ${ }^{207}$, em equilíbrio com os direitos fundamentais. Desse modo, pela leitura do art. 536 do CPC de 2015, não se permitiu que o postulado do pacta sunt servanda cedesse completamente frente à incoercibilidade da vontade humana:

“art. 536. No cumprimento de sentença que reconheça a exigibilidade de obrigação de fazer ou de não fazer, o juiz poderá, de ofício ou a requerimento, para a efetivação da tutela específica ou a obtenção de tutela pelo resultado prático equivalente, determinar as medidas necessárias à satisfação do exequente.

$\S 1$ o Para atender ao disposto no caput, o juiz poderá determinar, entre outras medidas, a imposição de multa, a busca e apreensão, a remoção de pessoas e coisas, o desfazimento de obras e o impedimento de atividade nociva, podendo, caso necessário, requisitar o auxílio de força policial.”

O artigo supracitado do Novo Código de Processo Civil propõe, portanto, uma leitura do artigo 248 do Código Civil de $2002^{208}$, na medida em que a resolução da obrigação em perdas e danos só se dará quando não for possível executá-la, ainda que minimamente.

"Se, todavia, ainda é possível cumprir-se a obrigação pactuada, deve a ordem jurídica buscar satisfazer o credor com a efetiva prestação pactuada, proporcionando, na medida do praticamente possível, que quem tem um direito receba tudo aquilo e precisamente aquilo que tem o direito de receber, e não impor indenizações

\footnotetext{
205 "The remedy of specific performance should be as routinely available as the damages remedy." SCHWARTZ, Alan. The Case for Specific Performance In: POSNER, Richard A.; PARISI, Francesco, Economic Foundations of Private Law, Massachusetts: Edward Elgar, 2002. p. 385. Tradução livre: O remédio da performance específica deveria ser tão aplicado quando as perdas e danos.

${ }^{206}$ GAGLIANO, Pablo Stolze; PAMPLONA Filho, Rodolfo. Op. cit., p.96.

207 "Nemo praecise cogi ad factum."

${ }^{208}$ Art. 248 CC/2002: "Se a prestação do fato tornar-se impossível sem culpa do devedor, resolver-se-á a obrigação; se por culpa dele, responderá por perdas e danos."
} 
equivalentes, haja vista que isso não realiza o bem da vida pretendido"209

Dessa maneira, a área de aplicação do instituto das perdas e danos se restringe a hipótese em que o autor próprio a requer ou se for impossível a tutela específica ou o resultado desta não for equivalente ao acordado, nos temos do art. 499 do $\mathrm{CPC} / 2015 .{ }^{210}$ As mesmas regras serão aplicadas às obrigações de entregar coisa certa, nos termos do art. 498 e 538 do CPC/2015 211 , prevalecendo, assim, a força obrigatória do pacto em detrimento da incoercibilidade da vontade.

Em relação à entrega de coisa, segue Álvaro Villaça Azevedo na mesma linha dos que entendem poder ser o devedor constrangido a fazê-lo. Contudo, em relação à obrigação de fazer ou não fazer, sua visão se mostra tendente à resolução do conflito por meio de perdas e danos:

“...aquele que se compromete a dar alguma coisa pode ser constrangido a entregá-la, por autoridade da justiça, quando a coisa se encontrar em seu poder, quer queira quer não queira o devedor. Já quem se obrigada a fazer alguma coisa não pode ser constrangido a faze-la, resolvendo-se a obrigação em perdas e danos, quando não dor ela cumprida devidamente". ${ }^{212}$

Nesta linha, a interpretação do art. 248 do CC 2002 seria a de que a obrigação de fazer não poderia ser executada com o constrangimento físico do devedor, resumindo-se a impossibilidade no cumprimento obrigacional em resolução da obrigação (em caso de não haver culpa do devedor) ou perdas e danos (no caso de culpa). Não parece ter sido esta a vertente adotada pelo Novo Código de Processo Civil, que optou por conceder força ao vínculo obrigacional

\footnotetext{
${ }^{209}$ GAGLIANO, Pablo Stolze; PAMPLONA Filho, Rodolfo. Op. cit., p. 100.

${ }^{210}$ Art. 499 CPC: "A obrigação somente será convertida em perdas e danos se o autor o requerer ou se impossível a tutela específica ou a obtenção de tutela pelo resultado prático equivalente."

${ }^{211}$ Art. 498 CPC: "Na ação que tenha por objeto a entrega de coisa, o juiz, ao conceder a tutela específica, fixará o prazo para o cumprimento da obrigação."

Art. 538 CPC. "Não cumprida a obrigação de entregar coisa no prazo estabelecido na sentença, será expedido mandado de busca e apreensão ou de imissão na posse em favor do credor, conforme se tratar de coisa móvel ou imóvel."

${ }^{212}$ AZEVEDO. Álvaro Vilaça. Op. cit., p. 48.
} 
formado no momento do pacto, em detrimento da intangibilidade da vontade humana. ${ }^{213}$

\subsection{Cláusula Penal e autonomia privada}

Pensando na compensação pela ruptura do contrato e remetendo-se à ideia de finalizar o ciclo do contrato de maneira semelhante àquele que teria ocorrido caso não houvesse o descumprimento, o ordenamento jurídico concede certa discricionariedade aos contratantes. Com fundamento no princípio da autonomia privada, é possível que credor e devedor estipulem um pacto acessório ao objeto principal do contrato, por meio do qual se antecipa a indenização devida em caso de inadimplemento. Este pacto é chamado de cláusula penal ou convencional, capaz de liquidar antecipadamente os danos na hipótese de descumprimento futuro. É exatamente o caso do contrato estipulado entre Antônio e Shylock. O objetivo de Shylock, ao sugerir a estipulação da Cláusula penal, era intimidar Antônio e ao mesmo coagi-lo a cumprir os termos da fiança. ${ }^{214}$

Isso demonstra que, além da previsão legal de responsabilidade decorrente do inadimplemento contratual (culpa, caso fortuito ou mora), o ordenamento também concede liberdade entre os contratantes para determinar mais uma ferramenta de desestímulo ao descumprimento do pacto. Ao mesmo tempo que a cláusula penal possui função de liquidar previamente os danos

\footnotetext{
${ }^{213}$ Somente com este aspecto do ordenamento vigente, sem levar em consideração argumentos de cunho social, o julgamento seguiria a favor de Shylock. Uma vez que Antônio concordou em entregar uma libra de carne ou se submeter à retirada da mesma, a força obrigacional do pacto ao qual manifestou a favor sua vontade, seria suficiente para exigir que o fiador se entregasse ou se submetesse à retirada da garantia. Felizmente para Antônio, outros aspectos econômicos do pacto ainda deveriam ser analisados antes da sentença.

${ }^{214}$ No fundo, no momento do pacto, Shylock também se deliciava com a possibilidade de poder cobrar a garantia da libra de carne, mas não acredita que realmente poderia fazê-lo até descobrir que os navios de Antônio não haviam retornado, o que o tornaria inadimplente e permitiria a cobrança da cláusula.
} 
decorrentes de um possível inadimplemento, também serve para estimular o devedor a honrar o vínculo obrigacional formado com o credor.

Nas palavras de Pablo Stolze e Rodolfo Pamplona Filho esta segunda função, não menos importante do que a liquidação dos danos, "atua muito mais no âmbito psicológico do devedor, influindo para que ele não deixe de solver o débito no tempo e na forma estipulados." 215 Era precisamente o que Shylock pretendia: atuar no psicológico de Antônio, que, a cada dia que se passasse e os navios não retornassem, ficando mais próximo o dia do pagamento, dormiria e acordaria mais assustado com a possibilidade de efetuar a garantia.

No entanto, é justamente a estipulação da cláusula penal como pacto acessório de garantia da obrigação contratual principal que salvaria Antônio sob a luz do ordenamento vigente. A cláusula penal ou stipulatio penae deve ser passível de conversão pecuniária, ou seja, necessita de um valor econômico para que sua estipulação seja válida. ${ }^{216}$ Ao contrário, na peça, quando Salarino, um dos amigos de Antônio e Bassânio pergunta ao credor para que ele usará a libra de carne, Shylock responde que a carne não lhe serve de nada. Diz que talvez sirva como isca para os peixes e se também não servir para alimentar coisa alguma, serviria para alimentar sua vingança. ${ }^{217}$ Essa passagem mostra que, sob as regras legais de hoje, sem nem mesmo entrar na seara de dignidade da pessoa humana, é inválida a cláusula uma vez que o objeto da garantia não possui valor econômico. Assim, tangencia-se a questão da utilidade econômica do objeto pactuado.

Se as ideias de Cesare Beccaria ${ }^{218}$ pudessem ser moldadas a este caso, dir-se-ia que se trata mais de utilidade econômica do que de justiça social. Ainda

\footnotetext{
215 GAGLIANO, Pablo Stolze; PAMPLONA Filho, Rodolfo. Op. cit., p. 375.

216 "Essa penalidade pode consistir no pagamento de uma soma em dinheiro, ou no cumprimento, de qualquer outra obrigação seja de dar outro objeto, seja de realizar uma atividade, mas desde que exista a possibilidade de ela converter-se pecuniariamente.” AZEVEDO, Álvaro Vilaça. Op. cit., p. 225.

${ }^{217}$ Salarino: "What's that good for?; Shylock: "To bait fish withal: if it will feed nothing else, it will feed my revenge". "O Mercador de Veneza": Ato III, Cena I.

${ }^{218}$ BECCARIA, Cesare. Dos delitos e das penas. $3^{\mathrm{a}}$ ed. Tradução de J. Cretella Jr. e Agnes Cretella. São Paulo: Revista dos Tribunais, 2006. p. $74-80$.
} 
que Beccaria se referisse à questão da pena de morte, argumentava que esta era desnecessária não porque era injusta, mas porque lhe faltava utilidade. Ao caso de Shylock e Antônio, a mesma ideia pode ser aplicada para afirmar que a cláusula penal que estipula o pagamento de uma libra de carne do devedor não deve preponderar, não devido à justiça, mas porque não possui utilidade para a circulação de bens do universo jurídico. A cláusula estipulada por Shylock tinha a intenção de satisfazer um sentimento vingativo, mas é também vazia de utilidade econômica. ${ }^{219}$

Ora, se Shylock negasse que havia dito a Salarino que a carne não the valia de nada ou se este não testemunhasse contra aquele, poderia Shylock cobrar a libra de carne, argumentado que possuía sim valor econômico? Não. Isso porque durante o julgamento, Bassânio oferece a Shylock três vezes o valor original do contrato para livrar Antônio da garantia, mas ele recusa, dizendo que não abriria mão da libra de carne. ${ }^{220}$ Isso significa que se a garantia tem valor econômico e se o credor não aceita três vezes o contrato original em seu lugar, então o objeto do pacto acessório é mais valioso do que o objeto do contrato principal, o que não é permitido.

A garantia estipulada na cláusula penal não pode ser economicamente mais valiosa do que o próprio objeto do contrato principal, sendo também o motivo pelo qual o objeto da cláusula acessória precisa ser economicamente passível de estimação. Caberia ao Doge de Veneza então reduzir o montante da

\footnotetext{
219 Acerca da possibilidade de obrigações envolvendo cobrança de direitos existenciais (cujo objeto pactuado constituiu um bem essencial ou um interesse existencial para uma das partes), Pietro Perlingieri afirma que "onde o objeto de tutela é a pessoa, a perspectiva deve mudar: torna-se necessidade lógica reconhecer, pela especial natureza do interesse protegido, que é justamente a pessoa a constituir ao mesmo tempo o sujeito titular do direito e o ponto de referência objetivo de relação." PERLINGIERI, Pietro. Perfis do Direito Civil: Introdução ao direito civil constitucional. Tradução de Maria Cristina De Cicco. $3^{\mathrm{a}}$ ed. Rio de Janeiro: Renovar, 2002. p. 155. Desta forma, os contratos existenciais, por serem caracterizados pela essencialidade do objeto em relação à pessoa, permitem a atuação do intérprete de modo a preservar o mínimo existencial. Considerando a libra de carne objeto do contrato entre Antônio e Shylock como um direito individual, ter-se-ia que analisar a essencialidade do bem tal como interesse existencial, ao invés de sua utilidade puramente econômica.

${ }^{220} \mathrm{Em}$ virtude da unicidade da prestação, Shylock não era obrigado a aceitar coisa diversa da pactuada, sendo sua recusa legítima. Tampouco se está diante de uma prestação alternativa, onde poderia o devedor escolher se entregava pecúnia ou a libra de carne, uma vez que isto não foi disposto no contrato.
} 
pena, tal como ordena o Código Civil de 2002, segundo o qual sendo a pena excessiva aos olhos da lei, deve o juiz reduzi-la. ${ }^{221}$ Assim sendo, com o objetivo de proteger as relações jurídicas de natureza econômica, a lei contratual se mune de um mecanismo, livremente pactuado pelas partes, a fim de impedir a ruptura do pacto.

Sendo a cláusula uma discricionariedade dos contratantes, ela não será válida se ofender princípios legais ou for contra a ordem pública, ainda que seu objetivo seja resguardar a força obrigacional do contrato. Além destas limitações, a cláusula penal também se depara com os limites de cunho econômico, como a possibilidade de conversão pecuniária do objeto da garantia e a impossibilidade de seu valor ser maior do que aquele do objeto principal. Com isso, garante-se equilíbrio à relação contratual e às expectativas do credor, ao mesmo tempo em que se mantém o devedor incentivado a cumprir o pacto, promovendo ainda a circulação de bens e direitos no comércio jurídico, encontrando limite na própria natureza econômica do contrato.

\footnotetext{
${ }^{221}$ Art. 413 CC/2002: “A penalidade deve ser reduzida equitativamente pelo juiz se a obrigação principal tiver sido cumprida em parte, ou se o montante da penalidade for manifestamente excessivo, tendo-se em vista a natureza e a finalidade do negócio."
} 


\section{CAPÍTULO 4 - A CORTE DE VENEZA E O DIREITO CIVIL CONSTITUCIONAL}

\subsection{O contrato como ferramenta das mudanças sociais}

Uma vez realizada a análise do Direito Contratual fazendo uso somente da principiologia clássica fica evidente que esta, por si só, também é dotada de raciocínio jurídico capaz de levar a desfechos semelhantes àqueles que chegarse-ia usando os princípios pós-modernos. Ainda que sob uma perspectiva funcional econômica, fica provado que seria possível analisar um pacto, mitigando a obrigatoriedade do mesmo por aspectos puramente econômicos, sem tocar na questão social, obtendo resultado parecido, ainda que por via distinta. Isso quer dizer que os "novos" paradigmas contratuais (boa-fé, equilíbrio econômico e função social do contrato) garantem a funcionalização dos contratos a caminho do desenvolvimento de relações solidárias, mas é equivocado dizer que concedem racionalidade plena ao Direito Contratual e que evitam "injustiças".

O Direito Contratual clássico não era irracional pelo fato de não dar ênfase ao aspecto social. Tampouco era injusto por representar os valores jurídicos que triunfaram com o liberalismo econômico no séc. XIX. Tal deve ser visto, não como antagonista do Direito Contratual contemporâneo, mas como uma etapa necessária na evolução deste instituto jurídico. Para analisar em que medida se deu esta evolução, neste capítulo, far-se-á uma releitura da peça "O Mercador de Veneza" sob a atual perspectiva Civil Constitucional. Assim, será possível medir até que ponto os "novos" princípios se sobrepõem aos dogmas 
clássicos fundadores da força obrigatória do contrato. O objetivo será constatar se aqueles sobrevivem conjuntamente ou em substituição a estes.

O Direito Contratual não possui uma única feição. Em sua dimensão jurídica, o conceito "contrato" engloba uma séria de princípios e regras de direito. Por outro lado, o conceito reflete também uma realidade exterior, entrelaçada por interesses, relações sociais e situações econômicas. Dessa maneira, para compreender o contrato, é necessário entendê-lo não como uma construção puramente jurídica, mas também como uma ferramenta evolutiva das operações socioeconômicas. ${ }^{222} \mathrm{O}$ contrato, para o Direito, seria a formalização jurídica desta troca econômica, ou como conceituou Enzo Roppo, "Disse-se que o contrato é a veste jurídico-formal de operações econômicas." 223

Essas operações econômicas constituem um processo de evolução que se dá com o desenvolver da civilização, dos costumes e dos reflexos sociais e, segundo Antonio Carlos Wolkmer, "o Direito sempre é produto da vida organizada enquanto manifestação de relações sociais provenientes de necessidades humanas". ${ }^{224}$ Com isto, ainda que o contrato seja uma figura jurídica autônoma e um instrumento com finalidades econômicas, não é possível

\footnotetext{
${ }^{222}$ Esta evolução jurídica influencia sobretudo na autonomia de gêneros contratuais distintos. Ainda que o descaso com a diferenciação dos contratos civis e mercantis tenha dificultado o estudo daqueles como categoria realmente autônoma e diminuído a preocupação com a sistematização de uma teoria geral dos contratos mercantis, o direito comercial é regido por uma racionalidade e história próprias que construíram e reconstruíram seus princípios basilares através dos séculos. Em especial a boa-fé e a equidade contribuíram para a relação entre os comerciantes: "A partir do séc. XIV vários estatutos dos mercadores na Idade Média impunham aos juízes o dever de sentenciar conforme a boa-fé, bem como prescreviam que os mercadores deveriam manter em boa-fé os contratos e as promessas recíprocas. Os termos 'boa-fé' e 'equidade' teriam sido empregados para referir três condutas esperadas dos contratantes, ainda que não expressamente acordadas: i) cada um deveria manter sua palavra; ii) nenhuma deveria tirar vantagem da outra mediante sua indução em erro; e iii) ambos deveriam pautar seu comportamento de acordo com as obrigações de uma pessoa honesta." FORGIONI, Paula A. Teoria geral dos contratos empresariais. $2^{\circ}$ ed. São Paulo: Revista dos Tribunais, 2010. p $37-44$, 107. Foi o contrato e a evolução dos institutos jurídicos que o permeiam e circundam que possibilitou o desenvolvimento da atividade mercantil rumo à atividade empresarial como se conhece hoje. Diz a absoluta verdade José Engrácia Antunes quando afirma que "para os comerciantes, o contrato representa um dos mais importantes, senão o mais importante instrumento de atividade empresarial". ANTUNES. José A. Engrácia. Direito dos Contratos Comerciais. Coimbra: Almedina, 2009. p. 39-40.

${ }^{223}$ ROPPO, Enzo. O Contrato. Tradução de Ana Coimbra e M. Januário C. Gomes. São Paulo: Almedina, 2009. p. 11.

${ }^{224}$ WOLKMER, Antônio Carlos. História do direito no Brasil. $3^{\mathrm{a}}$ ed. Rio de Janeiro: Forense, 2002. p 24.
} 
separá-lo das influências principiológicas do contexto social. Portanto, tomando como ponto de partida o contrato como reflexo da sociedade e da História ${ }^{225}$, é possível compreender de que maneira o aspecto liberal dos contratos e a chamada autonomia da vontade cederam espaço para novos princípios norteadores da relação contratual. É preciso analisar, historicamente, o que, em primeiro lugar, tornava esses dogmas clássicos tão importantes.

Isso remete ao tempo do fim do apogeu das sociedades feudais ${ }^{226}$ e o início da consolidação da sociedade burguesa que, segundo Wolkmer, levou à produção de uma nova cultura jurídica ao longo dos séculos XVII e XVIII na Europa Ocidental. ${ }^{227}$ Com o térmico do sistema de privilégios feudais e a intensificação do comércio, surge a necessidade de imposição de ideologias que tocam a liberdade e a autonomia do indivíduo. Segundo Roppo, para a sociedade revolucionária burguesa, a liberdade de contratar elevava o contrato ao eixo fundamental da sociedade liberal, dos seus valores e dos seus princípios, em oposição ao modelo de privilégios corporativos e a economia fechada da sociedade feudal. ${ }^{228}$ Isso fez com que o contrato assumisse um valor ideológico e político.

Em um momento onde as revoluções burguesas deram origem a sociedades liberais, buscava-se dar máxima importância à liberdade individual por meio do mecanismo contratual. Portanto, não houve espaço para limitações

\footnotetext{
225 "Examinar e problematizar as relações entre a História e o Direito reveste-se hoje da maior importância, principalmente quando se tem em conta a percepção da normatividade extraída de um determinado contexto histórico definido como experiencia pretérita que conscientiza e liberta o presente". Ibid. p. 11.

226 "Feudalismo é uma palavra muitas vezes carregada de um peso negativo que não é justo. Muitos, ao ouvi-la, lembram-se de atraso ou qualquer outro termo que possa ser empregado pejorativamente (...) é preciso entender que feudalismo é um sistema que não pode ser minimizado ou considerado apenas em parte. Esse sistema apoia-se no Direito e dele não pode se afastar, mas envolve meio de vida, força, fé, interesses, terra, divisão social e tudo quanto o ser humano é capaz de criar" CASTRO, Flávia Lages de. História do Direito: Geral e Brasil. 8ª ed. Rio de Janeiro: Lumen Juris, 2011. p. 120 - 121.

227 "A cultura jurídica produzida ao longo dos séculos XVII e XVIII na Europa ocidental, resultou de um complexo especifico de condições engendradas pela formação social burguesa, pelo desenvolvimento econômico capitalista, pela justificação de interesses liberal-individualistas e por uma estrutura estatal centralizada." WOLKMER, Antônio Carlos. História do direito no Brasil. p 24 ${ }^{228}$ ROPPO, Enzo. Op. cit., p. 28.
} 
oriundas de conceitos como igualdade, justiça, ambos suprimos e assegurados pela própria liberdade de contratar e pela paridade dos cidadãos perante a lei. ${ }^{229}$ Foi a autonomia individual refletida na vida privada, que concretizou a liberdade conquistada:

"O liberal individualismo, enquanto princípio fundamental que surge das condições materiais emergentes e das novas relações sociais tornou-se proposta ideológica adequada às necessidades de um novo mundo, bem como À legitimação das novas formas e produção da riqueza e à justificação racionalista da era que nascia. $\mathrm{O}$ individualismo como expressão da moralidade social burguesa enaltece o homem como centro autônomo de escolhas econômicas políticas e racionais; faz do seu individual um valor absoluto. ${ }^{230}$

Desde então, a relação do contrato jurídico com os valores ideológicos da sociedade se manteve indissolúvel na medida em que o Direito Contratual passou a ser utilizado com uma função ideológica. ${ }^{231}$ Vigorava a ideia da liberdade de contratar, fundamentada na soberania individual de escolha e na plena autonomia, onde limites não eram bem vistos. ${ }^{232}$ Os limites negativos eram tolerados até um certo ponto ${ }^{233}$, concedendo-se máxima eficácia à liberdade contratual. $\mathrm{O}$ resultado era a absoluta liberdade para se contratar, mas uma vez feito isto, a palavra dada era irrevogável. Mais ainda, descumprir era mentir e isto constituía verdadeiro pecado. ${ }^{234}$

\footnotetext{
${ }^{229}$ Esta paridade ou posição jurídica formal decorria do fato de que haviam sido abolidos os privilégios feudais. Ibid. p. 28.

${ }^{230}$ WOLKMER, Antônio Carlos. Op. cit., p. 25.

231 "O contrato é outro símbolo máximo do poder da vontade individual numa estrutura socioeconômica capitalista. O exacerbado individualismo da livre contratação e da autonomia da vontade funciona através do chamado negócio jurídico, um instrumento de auto-regulamentação dos interesses particulares." Ibid. p. 29.

232 "O mercado como sistema social e a liberdade das trocas imporá a obrigatoriedade das promessas (a individualização do contrato, com uma teoria da vontade e da autonomia da vontade, e da propriedade e sua livre aquisição e transferência)". LOPES, José Reinaldo de Lima. O direito na história: Lições introdutórias. $4^{\mathrm{a}}$ ed. São Paulo: Atlas, 2012. p. 165.

${ }^{233}$ Como exemplo, tem-se os limites à liberdade de contratar na tutela de sujeitos cujas condições psicofísicas lhes colocavam em situação de risco, como menores e doentes mentais. Uma maior resistência se dera diante da tentativa de introdução de limites destinados também a proteger os sujeitos cuja debilidade era socioeconômica. ROPPO, Enzo. Op. cit., p. 33.

234 "Por seu turno, os canonistas, imbuídos do espiritualismo cristão interpretavam as normas de Direito Romano animados de uma inspiração mais elevada. No tocante ao contrato, racionaram que o seu descumprimento era uma quebra de compromisso, equivalente à mentira; e como esta constituía
} 
A questão ideológica refletida no Direito Obrigacional um dia alimentara a liberdade como máxima do Direito Contratual pois, naquele momento, era necessário que a autonomia individual fosse considerada como máxima nas relações. Hoje, ela impulsiona a função social do contrato e abre espaço para instrumentos sociais ligados ao Direito Contratual e à construção da solidariedade. ${ }^{235}$ Isso significa que o mecanismo jurídico chamado de contrato serviu como ferramenta para impor as mudanças sociais necessárias à evolução da sociedade e atualmente se destina à concretização de princípios constitucionais sociais e plúrimos. ${ }^{236}$

Da mesma maneira que a ideologia revolucionária burguesa procurou firmar caminho para uma sociedade liberal, fazendo uso da liberdade contratual, a sociedade por trás da Constituição de 1988 procurou abrir passagem para o mundo jurídico pós-moderno, refletindo sua principiologia também no Direito Obrigacional. O novo modelo constitucional significou também uma "revolução", com o estabelecimento do Estado Democrático de Direito e a consequente ruptura com um regime constitucional autoritário, garantindo as relações democráticas entre o Estado e a Sociedade.

peccatum, faltar ao obrigado atraia as penas eternas. Não podia ser, para os jurisconsultos canonistas, predominante a sacramentalidade clássica, mas sobretudo prevalecia o valor da palavra, o próprio consentimento. PEREIRA, Caio Mário da Silva. Instituições de Direito Civil. Contratos. 17ª ed. Rio de Janeiro: Forense, 2013. v. 3. p. 16.

235 "O homem natural, isolado, que nasce livre e independente dos outros homens, e com direitos constituídos por essa mesma liberdade e essa mesma independência, é uma abstração alheia à realidade. De fato, o homem nasce membro de uma coletividade; viveu sempre em sociedade e só pode viver em sociedade, e o ponto de partida de qualquer doutrina sobre o fundamento do direito deve ser, sem dúvida, o homem natural; mas o homem natural não é o ser isolado e livre dos filósofos do século XVIII; é o indivíduo implicado nos laços da solidariedade social. "DUGUIT, Léon. Fundamentos do Direito. São Paulo: Servanda, 2008. p. 15.

${ }^{236}$ Sob a perspectiva mercantil, ainda que seja a liberdade contratual responsável pelo impulsionamento do mercado, as regras que a limitam nos contratos e interferem no processo negocial, protegem as atividades econômicas de atitudes abusivas cometidas em nome desta mesma liberdade. Para Fernando Araújo, uma posição de pura sacralização da autonomia privada não permitiria a anulação de contratos com fins ilícitos ou que fizessem uso da escravidão voluntária, prisão ou servidão no caso de descumprimento. Também não permitiria a responsabilidade pré-contratual ou a avaliação do desequilíbrio de onerosidade das obrigações, vendando ainda a detecção de situações lesivas e gritantemente injustas. Por isso, explica o autor, "há uma margem de paternalismo que é, por assim dizer, inerradicável.” ARAÚJO, Fernando. Teoria Econômica do Contrato. Coimbra: Almedina, 2007. p 442. 
Se antes o Direito Civil e o Direito Constitucional se enquadravam em áreas diferentes do sistema jurídico e suas ideias não se tocavam, o novo aparato jurídico constitucional alongou-se para todas as áreas do Direito. A evolução aconteceu lentamente. Primeiro, houve a mudança decorrente da substituição do Estado Liberal pelo Estado Social ${ }^{237}$, mas isso ainda não era suficiente para que a Constituição alcançasse o status normativo que tem hoje. Somente com o posterior reconhecimento da força normativa de toda a Constituição, em especial dos princípios, conceber-se-ia o ordenamento como uma unidade, estruturada pela Lei Maior. ${ }^{238}$

Como afirma Lenio Streck, a Constituição passa a ser o topos $^{239}$ hermenêutico que conforma a interpretação do restante do sistema jurídico, alastrando-se para além do sistema propriamente constitucional. ${ }^{240}$ Assim, do mesmo modo que a Carta de 1988, sendo uma Constituição social, regulamenta a sociedade e objetiva o bem-estar social, também o fariam as demais áreas do sistema jurídico:

"A Constituição é, assim, a materialização da ordem jurídica do contrato social, apontando para a realização da ordem política e social de uma comunidade, colocando à disposição os mecanismos para a concretização do conjunto de objetivos traçados no seu texto normativo deontológico. Por isto, as constituições sociais devem ser interpretadas diferentemente das Constituições Liberais. O plus normativo representado pelo Estado Democrático de Direito resulta como um marco definidor de

\footnotetext{
237 "No paradigma do Estado Liberal, a Constituição não se imiscuía no campo das relações privadas. Estas eram disciplinadas pela legislação ordinária, que gravitava em torno do Código Civil, centrado na proteção da segurança jurídica, tão vital aos interesses da burguesia. Com o surgimento do Estado social, multiplicou-se a intervenção do legislador no campo privado. (...) A Constituição se projetou no campo civil, disciplinando, a traços largos, a economia e o mercado e consagrando valores solidarísticos". SARMENTO, Daniel. Direitos Fundamentais e Relações Privadas. $2^{\mathrm{a}}$ ed. Rio de Janeiro: Lumen Juris, 2010. p. 49.

${ }^{238}$ A Lei Maior representa não apenas o limite para o legislador, mas também o norte da sua atuação e o centro unificador de todo o direito infraconstitucional. Tal concepção vai acarretar uma verdadeira "virada de Copérnico" no Direito Privado, reunificando, em torno dos seus valores existenciais, um sistema que fora fragmentado pelo advento de um sem-número de leis especiais. Esses valores vão fecundar o Direito Privado com os ideais igualitários e solidarísticos entranhados no tecido constitucional, impondo uma releitura, sob nova ótica, de conceitos e institutos tradicionais, elaborados em outro contexto social e axiológico. Ibid. p. 50-51.

${ }^{239}$ Em grego, significa uma máxima do senso comum.

${ }^{240}$ STRECK, Lenio. Hermenêutica jurídica e(m) crise: Uma exploração hermenêutica da construção do direito. $10^{\mathrm{a}}$ ed. Porto Alegre: Livraria do Advogado, 2011. p. 311.
} 
um constitucionalismo que soma a regulação social com o resgate das promessas da modernidade." ${ }^{241}$

Nesta linha, os princípios constitucionais pós-positivistas ganham tamanho espaço na desenvoltura da ordem jurídica que sua violação é mais grave do que a transgressão de uma regra. ${ }^{242} \mathrm{~A}$ força dos "novos" princípios constitucionais os torna capazes de mitigar dogmas anteriores, garantindo que os novos valores acompanhem a dinâmica da sociedade moderna. Portanto, do mesmo modo que fora preciso influenciar o sistema com a "autonomia da vontade" e, tendo como consequência a elevação do postulado pacta sunt servanda como máxima das relações, a partir de 1988 seria preciso concretizar os valores constitucionais por meio dos aparatos legais. A partir de então, a dificuldade consiste em encontrar o equilíbrio razoável entre a liberdade e a concretização dos direitos fundamentais. ${ }^{243}$

\subsection{A Constituição de 1988 e o Direito Civil Constitucional}

O Direito Civil Constitucional deve ser entendido como a constante releitura do Direito Civil à luz da constituição. É por este motivo que Maria Celina Bodin afirma que o Direito Civil Constitucional representa o conjunto de valores sobre os quais se constrói o pacto de convivência coletiva, função que já foi exercida pelos Códigos Civis. ${ }^{244}$ Nesse mesmo sentido, Pietro Perlingieri

\footnotetext{
${ }^{241}$ STRECK. Lênio. Op. cit., p. 312.

${ }^{242}$ Discordaria Eros Grau, que afirma: “A esta altura desejo observar que o princípio é um tipo de regra de direito. A afirmação de que seria mais grave violar um princípio do que uma violar uma norma consubstancia uma tolice" GRAU, Eros Roberto. Ensaio e Discurso sobre a Interpretação/ Aplicação do Direito. $4^{\text {a }}$ ed. São Paulo: Malheiros, 2006. p. 22.

${ }^{243}$ Para Maria Celina Bodin o maior problema do Direito na atualidade "tem sido exatamente o de estabelecer um compromisso aceitável entre os valores fundamentais comuns, capazes de fornecer enquadramentos éticos nos quais as leis se inspirem, e espaços de liberdade, os mais amplos possíveis, de modo a permitir a cada um a escolha de seus atos e o direcionamento de sua vida particular, de sua trajetória individual." ${ }^{243}$ MORAES, Maria Celina Bodin de. Danos à Pessoa Humana: Uma Leitura Civil Constitucional dos Danos Morais. 2a ed. Rio de Janeiro: Processo, 2017. p. 71.

${ }^{244}$ Ibid. p. 70.
} 
afirma que o Código Civil perdeu a centralidade que um dia já teve e que, hoje, o papel de unificação do sistema jurídico é da Constituição. ${ }^{245}$ Isso porque, cada vez mais, percebe-se que respeitar os valores e princípios fundamentais da República é condição para a concretização de uma relação entre o Estado e os governados e entre os próprios indivíduos. Assim, surge o dever de refletir as situações jurídicas dando prioridade às normas constitucionais, devido a sua posição hierárquica. Para Perlingieri,

\begin{abstract}
"a normativa constitucional não deve ser considerada sempre e somente como mera regra hermenêutica, mas também como norma de comportamento, idônea a incidir sobre o conteúdo das relações entre situações objetivas, funcionalizando-as aos novos valores. ${ }^{246}$
\end{abstract}

Segundo Maria Celina Bodin, os direitos fundamentais no Brasil, até a Constituição de 1988, serviam unicamente para que o indivíduo se defendesse de uma eventual ingerência do Estado. ${ }^{247}$ Com a Constituição Cidadã de 1988 isso mudou. Se fosse possível extrair o espírito da Constituição brasileira de 1988 para identificar a característica mais almejada para a sociedade, a resposta seria solidariedade. ${ }^{248}$ A dignidade da pessoa humana ${ }^{249}$ e a expressa perspectiva do valor social do trabalho e da livre iniciativa como valores fundamentais ${ }^{250}$ mostram a preocupação com os aspectos sociais das relações sociais.

\footnotetext{
245 PERLINGIERI, Pietro. Perfis do Direito Civil: Introdução ao direito civil constitucional. Tradução de Maria Cristina De Cicco. $3^{\mathrm{a}}$ ed. Rio de Janeiro: Renovar. 2002. p. 6.

${ }^{246}$ PERLINGIERI, Pietro. Op. cit., p. 12.

${ }^{247}$ MORAES, Maria Celina Bodin de. Op. cit., p. 70.

248“Se o Estado de Direito, iluminista e racional, se mostrou insuficiente para proteger a coletividade frente ao totalitarismo mais abjeto, tornou-se necessário abandonar a legalidade em sentido estrito, permissiva de arbitrariedades e ditaduras em direção a opções mais seguras, nas quais os princípios da democracia, liberdade e da solidariedade não possam jamais ser ignorados" Ibid. p. 67.

249 O que seria essa "dignidade inerente à espécie humana? Maria Celina Bodin explica que, etimologicamente, a palavra vem do latim dignus, que, na Antiguidade, significava "aquele que merece estima e honra, que é importante." Contudo, com o advento do Cristianismo, concebeu-se a ideia de uma dignidade atribuída a cada indivíduo, que deveria olhar não somente em direção a Deus, mas a si mesmo, para tomar consciência de sua dignidade e agir de modo compatível. Quanto ao fundamento jurídico, seria este em primeiro lugar na igualdade (tratamento não discriminatório), depois na integridade psicofísica, no direito à liberdade, e no direito-dever de solidariedade social. Ibid. p. 77-78, 86-117. ${ }^{250}$ Art. $1^{\text {a }}$, III e IV CF/88.
} 
O objetivo fundamental da República em garantir o desenvolvimento nacional deve estar condicionado à prevalência de uma sociedade livre, justa e solidária. ${ }^{251}$ Assim, pode-se afirmar que a leitura do Direito Civil à luz do Direito Constitucional serve como instrumento de proteção da pessoa e de resguardo ao indivíduo à sociedade em seu aspecto solidário. Em especial, a proteção da pessoa humana, em substituição à liberdade individual e a tutela da autonomia privada, é o aspecto que desencadeia as transformações ocorridas no sistema jurídico. ${ }^{252}$

$\mathrm{Na}$ medida em que a autonomia privada deixou de ser a maior preocupação da sociedade, abriu-se lugar para valores sociais e aconteceu a releitura do Direito Civil, à luz dos novos fundamentos e objetivos constitucionais. Ou seja, nasceu um Direito "que não mais encontrava nos valores individualistas codificados o seu fundamento axiológico". ${ }^{253}$ O Direito Obrigacional, por sua vez, passou a ter como preocupação, não a máxima liberdade dos pactos, e sim a concretização da sociedade livre, mas que fosse justa e solidária, por meio novos princípios: boa-fé, equilíbrio econômico e função social do contrato.

Com isso, a "autonomia da vontade" foi mitigada para dar lugar a uma reconceituação do instituto contratual. ${ }^{254} \mathrm{Ou}$ seja, o indivíduo atuando e pactuando em sua liberdade deixou de ser o foco do sistema, para dar lugar às questões relacionadas a dignidade da pessoa e a solidariedade social:

"Se, por um lado, a tutela da dignidade da pessoa difere da tutela do indivíduo, salientando aspectos sociais negligenciados pela ótica individualista, por outro, é

\footnotetext{
${ }^{251}$ Art. $2^{\circ}$ I e II CF/88.

${ }^{252}$ Segundo Maria Celina Bodin, essas transformações ocorreram não só no interior da ordem civil, mas também na aplicação da lei pelos juízes e, principalmente, na "consciência moral da sociedade". MORAES, Maria Celina Bodin de. Op. cit., p. 73.

${ }^{253}$ Ibid. p. 74.

254 "O homem vive em sociedade e só pode viver em sociedade; a sociedade subsiste apenas pela solidariedade que une os indivíduos que a compõe. Por consequência, uma regra de conduta impõe-se ao homem social pela própria força das coisas, e essa regra pode formular-se deste modo: nada fazer que atende contra a solidariedade social sob qualquer das suas formas, e fazer tudo o que for de natureza a realizar e a desenvolver a solidariedade social.” DUGUIT, Léon. Op. cit., p. 23.
} 
precisamente o valor reconhecido à pessoa que impede que seja a mesma transformada em instrumento (ao invés de fim), ainda que sob a justificativa da proteção de interesses que, sendo públicos, pudessem sobrepor-se a interesses exclusivamente privados." 255

Assim, para ao Direito Obrigacional, a releitura dos pactos em função do Direito Civil Constitucional significou mudanças radicais: o equilíbrio econômico trouxe a questão da paridade entre contratantes, a fim de garantir que as prestações pactuadas não fossem maculadas por desproporcionalidade. A função social elevou o contrato para fora da ótica individualista, impedindo que seja visto como uma relação que interessa unicamente aos contratantes, como se não refletisse na sociedade que o cerca e fosse intocável por ela. A boa-fé objetiva, por sua vez, modificou os critérios de interpretação de conduta das partes, impondo deveres conexos à relação contratual e limitando o exercício abusivo de um direito.

Isso não significa que os princípios que alimentavam o pacta sunt servanda foram esquecidos ou totalmente preteridos em razão dos princípios pós-modernos. Estes novos princípios não substituem os dogmas anteriores, mas passam a conviver com os princípios da autonomia privada, intangibilidade do conteúdo do contrato e a relatividade dos seus efeitos. Ambas as principiologias convivem lado a lado, aplicando-se ou deixando de se aplicar dependendo da natureza ou do objeto contratual por meio da ponderação. ${ }^{256} \mathrm{Na}$ medida em que a colisão entre princípios não gera necessariamente a invalidade de um deles, é preciso utilizar um instrumento para definir qual prevalecerá no caso de conflito. Assim, na hipótese de uma aparente antinomia principiológica contratual é

255 NEGREIROS, Teresa. Teoria do Contrato: Novos paradigmas. $2^{\mathrm{a}}$ ed. Rio de Janeiro: Renovar, 2006. p. 38.

256 “A ponderação, sem uma estrutura e sem critérios materiais, é instrumento pouco útil para a aplicação do Direito. É preciso estruturar a ponderação com a inserção de critérios. Isso fica evidente quando se verifica que os estudos sobre a ponderação invariavelmente procuram estruturar a ponderação com os postulados de razoabilidade e proporcionalidade e direcionar a ponderação mediante utilização dos princípios constitucionais fundamentais. Nesse aspecto, a ponderação, como mero método ou ideia geral despida de critérios formais ou materiais, é muito mais ampla que os postulados da proporcionalidade e da razoabilidade.” ÁVILA, Humberto. Teoria dos Princípios: da definição à aplicação dos princípios jurídicos. 14ª ed. São Paulo: Malheiros, 2013. p. 164- 165. 
possível fazer uso de um instrumento para determinar a principiologia aplicável caso específico: O paradigma da essencialidade.

O paradigma da essencialidade pode ser explicado como uma ferramenta utilizada para medir a extensão de aplicação de cada princípio a um caso específico. Para isso, é preciso pesar todos os elementos e circunstâncias essenciais ao contrato e contrabalancear a melhor principiologia aplicável à questão em análise. ${ }^{257}$ Não se trata, portanto, de maximizar os princípios sociais para cumprir o objetivo fundamental da República, deixando a liberdade individual nas sombras do Direito. Trata-se de alcançar o equilíbrio entre a valorização da pessoa, nas suas relações em sociedade e a liberdade da vontade individual.

\subsection{O paradigma da essencialidade}

O eventual choque entre princípios não significa que o ordenamento seja incoerente. A pluralidade de princípios distintos serve justamente para conferir coerência ao sistema jurídico. Uma possível colisão é somente o caminho para atingir o fim, pois o que se chama de paradigma da essencialidade nada mais é do que o exercício de uma ponderação de valores, objetivando o fim pretendido pelo legislador. Reconhecido o valor mais relevante para determinada situação, resolve-se o conflito de maneira a aplicar o princípio mais relevante ao caso concreto, levando em consideração a natureza do objeto em questão.

A questão da natureza do objeto leva em consideração que a visão exclusivamente patrimonialista da autonomia privada é incompatível com um

\footnotetext{
${ }^{257}$ Segundo Humberto Ávila, várias são as fases para a ponderação: a primeira delas é a preparação, com a análise de todos os argumentos, o mais extensivamente possível. A segunda é a realização da ponderação, fundamentando a relação entre os elementos objeto de sopesamento. No caso da ponderação de princípios, essa fase indica a relação de primazia entre um e outro. A terceira etapa é a reconstrução da ponderação, por meio da formulação de regras de relação, com a pretensão de validade para além do caso em questão." Ibid. p. 165 - 166.
} 
ordenamento que valoriza a pessoa humana. Isso significa que os contratos atingem também valores não patrimoniais, possibilitando a existência de relações jurídicas existenciais. Como afirma Pedro Marcos Nunes Barbosa, está ultrapassado o dogma da indisponibilidade dos valores existenciais. ${ }^{258}$ Neste sentido, contribui Teresa Negreiros:

"Os contratos que tenham por função satisfazer uma necessidade existencial do contratante devem sujeitar-se a um regime de caráter tutelar- ampliando-se, correlatamente, o campo de aplicação dos novos princípios. Ao revés, os contratos que tenham por objeto bens supérfluos, destinados a satisfazer preferências que não configuram necessidades básicas da pessoa, tais contratos são compatíveis com uma disciplina mais liberal, o que vale dizer que devem sofrer maior influência dos princípios clássicos. ${ }^{259}$

Para a análise principiológica no caso de " O Mercador de Veneza", quanto ao aspecto da retirada da libra de carne do devedor ou garantidor da dívida encontra-se um impasse: no contexto do ordenamento jurídico brasileiro pós Constituição de 1988, a proteção da pessoa humana sob a perspectiva da tutela psicofísica ${ }^{260}$ seria suficiente para resguardar a integridade física do devedor. Por isso, para possibilitar o exame dos princípios de natureza obrigacional ao caso em questão, deve-se contextualizar o julgamento em um cenário semelhante à Veneza do século XIV, onde era pactuável a parte do corpo como garantia. Sem admitir que a libra de carne seja objeto lícito, em nome da dignidade da pessoa humana, o conflito se resolveria aí e não seria preciso

\footnotetext{
258 BARBOSA, Pedro Marcos Nunes. A autonomia negocial nos contratos e impactos de natureza existencial: Alguns tópicos Polêmicos. Revista Escola da Magistratura Regional Federal 2a Região. Rio de Janeiro, v. 14. p. 179 - 202, nov. 2010.

${ }^{259}$ NEGREIROS, Teresa. Op. cit., p. 32.

${ }^{260}$ Ainda que no caso em questão a questão da integridade física seja literal, o direito a integridade psicofísica vai além, em razão da velocidade crescente da tecnologia. "Tradicionalmente, apenas o direito de não ser torturado e de ser titular de certas garantias penais, como o tratamento do preso nas detenções e nos interrogatórios, a proibição de penas cruéis e etc. Na esfera, cível, no entanto, a integridade psicofísica vem servindo a garantir numerosos direitos da personalidade (vida, nome, imagem, honra, privacidade, corpo, identidade, pessoal) (...) atualmente, as maiores perplexidades em torno do tema dizem respeito ao extraordinário desenvolvimento da biotecnologia e suas consequências sobre a esfera psicofísica do ser humano. Assim, por exemplo, no âmbito do que começa a se configurar como um novo ramo, o do Biodireito, ainda sem regulamentação jurídica adequada, estão problemas decorrentes da reprodução assistida." ${ }^{260}$ MORAES, Maria Celina Bodin de. Op. cit., p. 93 - 96.
} 
ponderar os princípios norteadores da obrigação contratual. Por uma questão de honestidade acadêmica, portanto, é preciso considerar que, no contexto histórico do julgamento, a pactuação da libra de carne é lícita, consistindo em um objeto de natureza existencial.

Tendo em mente um contrato com objeto admissível, mas levando em conta a sua natureza existencial, resta utilizar o paradigma da essencialidade para pesar os princípios aplicáveis ao caso, começando pela contraposição principiológica entre o equilíbrio das prestações e "autonomia da vontade". Aqui, o julgador se depararia com o desafio de analisar a proporção entre 3 mil ducados e uma libra de carne. Considerando a carne do corpo um objeto pactuável, restaria a dificuldade de determinar o valor de uma libra de carne humana, tendo em vista a inexistência de parâmetro no qual se basear. ${ }^{261}$ Somente com a desproporção seria possível mitigar a liberdade de contratar, de se vincular ao pacto e do objeto contratado. Aqui, o paradigma da essencialidade não ajudaria a pesar definitivamente o princípio mais aplicável ao caso, em razão da impossibilidade de se afirmar o valor da libra de carne. ${ }^{262}$

Passando à análise da função social do contrato em oposição à relatividade dos seus efeitos, a resposta é mais definitiva. A função social surge como um convite ao intérprete do Direito Civil, a fim de reler o ordenamento de modo a fazer com que a função social do contrato transcenda os interesses

\footnotetext{
261 Aqui, a interseção entre o direito e a economia, levando em conta o equilíbrio econômico das prestações, será de pouca ajuda. Segundo Fernando Araújo, a Microeconomia associava ao contrato algumas condições para a eficiência do mercado, qual seja, a ideia de uma fundamental equivalência entre o preço e demais condições nas trocas e condições de preço mais favoráveis, almejando a formação de um padrão objetivo de normalidade contratual, capaz de aferir a justiça nas trocas. ARAÚJO, Fernando. Teoria Econômica do Contrato. Coimbra: Almedina, 2007. p. 38. Aqui a análise econômica encontra seu limite, na medida que valores existenciais passaram a integrar o mecanismo contratual. 262 É preferível descaracterizar a aplicação da revisão do pacto em virtude da proteção da parte contratante mais frágil, sendo esta uma das possíveis interpretações do princípio do equilíbrio econômico. Ainda que as prestações fossem desproporcionais (uma libra de carne em garantia de 3 mil ducados), não há situação de necessidade do credor, fiador ou do devedor. Há somente interesses supérfluos. Antônio era responsável por uma garantia que servia para possibilitar que seu amigo cortejasse uma dama, não existindo perigo ou ameaça à existência econômica de nenhum dos dois. Essa situação não justificaria a diminuição do poder negocial dos contratantes, sendo a necessidade elemento essencial para a revisão contratual com base na fragilidade de algum dos pactuantes.
} 
egoístas dos contratantes, impedindo que o Direito Contratual seja governado pela máxima de que o contrato só faz efeitos entre as partes:

"A função social surge, sob esta ótica, como um ponto de referência da maior relevância na reformulação do princípio da relatividade. É com base na função social que ganha força a ideia de que o contrato não encerra uma relação posta entre parênteses, encapsulada, de interesse exclusivo para as parres que se encontram vinculadas contratualmente. ${ }^{263}$

A função social é um princípio de mão-dupla, onde de um lado se encontram os contratantes e do outro, terceiros estranhos à manifestação de vontade. No "meio", tem-se a sociedade. As partes devem pactuar pensando no desenvolvimento social ou, pelo menos, limitando-se a não o retardar. Deve-se inibir qualquer prejuízo eventual à coletividade, em virtude da relação estabelecida. ${ }^{264}$ Quanto aos terceiros, estes, devem agir de maneira a não desrespeitar o acordo firmado pelos contratantes em nome da solidariedade almejada pelo constituinte.

Considerando que "a liberdade de contratar será exercida em razão e nos limites da função social do contrato" 265 e que a função social atua de modo a concretizar a construção da solidariedade social, incabível seria permitir a retirada de uma libra de carne como garantia. ${ }^{266}$ Uma vez que a finalidade contratual não está restrita aos contratantes e possui repercussão na sociedade, o uso do corpo como garantia daria margem a uma série de contratos

\footnotetext{
263 TEPEDINO, Gustavo, BARBOSA, Heloísa Helena; MORAES, Maria Celina Bodin de. Código Civil Interpretado: Conforme a Constituição da República. $2^{\mathrm{a}}$ ed. Rio de Janeiro: Renovar, 2012. v.2. p. 14.

${ }^{264}$ É o que Paulo Nalin chama de perfil extrínseco e intrínseco da função social. Segundo o autor, este perfil tem como finalidade a coletividade e preocupa-se com suas repercussões no campo das relações sociais. NALIN, Paulo. Função social do Contrato no futuro código civil brasileiro. In: TEPEDINO, Gustavo; FACHIN, Luiz Edson (Org.) Obrigações e Contratos. São Paulo: Revista dos Tribunais, 2011. v. 3. p. $841-853$.

${ }^{265}$ Art. 421 CC/2002: “A liberdade de contratar será exercida em razão e nos limites da função social do contrato".

${ }^{266}$ É necessário encarar o princípio da função social do contrato sem levar em conta questões como dignidade da pessoa humana ou a proibição legal de dispor do próprio corpo como pagamento, que por si só já maculariam a cláusula estipulada por Shylock e Antônio.
} 
semelhantes. ${ }^{267}$ Uma vez que a finalidade das relações entre indivíduos não se reduz à vontade de quem a emite e sim à função desempenhada pelo contrato em sociedade, impensável seria permitir a construção de uma sociedade baseada em tais relações contratuais. ${ }^{268}$ De acordo com Teresa Negreiros,

"Partimos da premissa de que a função social do contrato, quando concebida como um princípio, antes de qualquer outro sentido e alcance que se lhe possa atribuir, significa muito simplesmente que o contrato não deve ser concebido como uma reação jurídica que só interessa às partes contratantes, impermeável às condicionantes sociais que o cercam e que são por ele afetadas." ${ }^{269}$

À luz dos sistemas constitucionais cujo objetivo fundamental é a construção de uma sociedade livre, justa e solidária ${ }^{270}$, a principiologia da função social é acompanhada pela boa-fé objetiva ${ }^{271}$, que passa a ser elemento essencial das relações jurídicas. Este é o último ponto a ser pesado para definir se a libra de carne poderia ser cobrada. Para isso, deve-se analisar se a boa-fé objetiva, neste caso, mitigaria a máxima da obrigatoriedade contratual. A relação entre os

\footnotetext{
${ }^{267}$ Bem como uma sociedade de mutilados.

${ }^{268}$ Proibição semelhante foi dada pela Lex Poetelia Papiria da República Romana, que aboliu o nexum ou a escravidão por dívida, fazendo com que o devedor fosse atrás do patrimônio do devedor e não do corpo. O nexum era o acordo pelo qual o devedor dava como garantia de um empréstimo a escravidão de si mesmo ou de um membro da família. Segundo Cândido Rangel Dinamarco, "a transformação principiou com a Lex Poetelia do ano 356 a.C, a qual ditou várias normas atenuadoras do sistema então vigente, a saber: a) proibiu a morte e o acorrentamento do devedor; b) institucionalizou o que antes era simples alternativa oferecida ao credor, ou seja, a satisfação do crédito mediante a prestação de trabalhos forçados; c) permitiu que o executado se livrasse da manus injectio, repelindo a mão que o prendia mediante o juramento de que tinha bens suficientes para satisfazer o crédito e acima de tudo d) extinguiu o nexum, passando então o devedor a responder por suas obrigações com o patrimônio que tivesse, não mais com o próprio corpo." DINAMARCO, Cândido Rangel. Execução Civil. $7^{\text {a }}$ ed. São Paulo: Malheiros, 2000. p. 44-45. De acordo com Caio Mário da Silva Pereira, a abolição da execução sobre a pessoa do devedor, constituiu verdadeira evolução no conceito obrigacional, uma vez que a responsabilidade se projetaria sobre os bens (pecuniae creditae bona debitoris, non corpus obnoxium esse). PEREIRA, Caio Mario da Silva. Instituições de Direito Civil: Teoria Geral das Obrigações. $25^{\text {a }}$ ed. Rio de Janeiro: Forense, 2012. v. 2. p. 10.

${ }^{269}$ NEGREIROS, Teresa. Op. cit., p. 208. Nesta mesma linha, Joseph Raz, afirma que o direito à liberdade econômica e contratual não existe em oposição à coletividade. Muito pelo contrário. Não é o objetivo da liberdade restringir a coletividade, pois ela depende de ao menos um de seus valores coletivos: a liberdade de mercado. RAZ, Joseph. The morality of freedom. Oxford: Clarendon Press, 1986. p. 253.

${ }^{270}$ Art. $3^{\circ}, \mathrm{I}, \mathrm{CF} / 88$.

${ }^{271}$ Enquanto a boa-fé subjetiva diz respeito às circunstâncias psicológicas do agente, o boa-fé objetiva é o princípio que restringe o exercício de direitos, por meio de normas de conduta que devem ser respeitadas.
} 
contraentes deve passar por um último filtro de cooperação entre as partes, de conduta e de exercício conforme, não abusivo de um direito:

\begin{abstract}
"Na promoção de uma ética de solidariedade contratual, o princípio da boa-fé opera de diversas formas e em todos os momentos da relação, desde a fase da negociação à fase posterior à sua execução, constituindo-se em fonte de deveres e de limitação de direitos de ambos os contratantes"272
\end{abstract}

O texto legal do Código Civil de 2002 aborda a questão da boa-fé objetiva em três dispositivos, cada qual manifestando o princípio de forma distinta. ${ }^{273}$ Ora serve como critério de interpretação da declaração de vontade, ora como valoração da abusividade no exercício de um direito e, por vezes, também serve como regra de conduta entre contratantes. ${ }^{274}$ Todas estas ramificações têm, segundo Teresa Negreiros, "um sentido e fim éticos, segundo os quais a relação contratual deve ser compreendida como uma relação de cooperação, impondose um dever de recíproca colaboração entre os contratantes". ${ }^{275}$

É justamente em uma relação mercantil como aquela formada entre Shylock e Antônio que a boa-fé tem uma função essencial e representa a ruptura com a maximização dos valores individualistas clássicos ${ }^{276}$. Interessa,

272 NEGREIROS, Teresa. Op. cit., p. 118.

${ }^{273}$ Art. 113. Os negócios jurídicos devem ser interpretados conforme a boa-fé e os usos do lugar de sua celebração; Art. 187. Também comete ato ilícito o titular de um direito que, ao exercê-lo, excede manifestamente os limites impostos pelo seu fim econômico ou social, pela boa-fé ou pelos bons costumes; Art. 422. Os contratantes são obrigados a guardar, assim na conclusão do contrato, como em sua execução, os princípios de probidade e boa-fé.

${ }^{274}$ No Código Civil do Consumidor a boa-fé também ganhou espaço nas relações envolvendo questões consumeristas (Art. 4, III e 51 IV), ainda que não sejam aplicáveis ao caso de Shylock e Antônio.

${ }^{275}$ NEGREIROS, Teresa. Op. cit., p. 130.

${ }^{276}$ Indiferente, no caso em questão, estar-se diante de um contrato firmado entre dois empresários no exercício de seus labores. A obrigatoriedade contratual e a máxima da "autonomia da vontade" não podem ser invocadas para justificar situações de abuso sob o fundamento econômico de impulsionamento da dinâmica da atividade comercial e alimentação do mercado. O limite da liberdade opera, segundo Darcy Andrade, "a reação da cité contra o indivíduo, compelindo-o a se integrar na ordem social", sendo ele ser atômico do organismo coletivo, que não poderia se afeiçoar aos seus egoísmos. ANDRADE, Darcy Bessone de Oliveira. Do direito do comerciante à renovação do arrendamento. Minas Gerais: Imprensa Oficial de Minas Gerais, 1940 p. 10. Significa que as variações da vida moderna, cada vez mais dinâmica, seja nas relações civis ou nas relações comerciais, se processam em ritmo acelerado a não podem mais ser conduzidas por fórmulas ultrapassadas. O homem, empresário ou não, tem função social a desempenhar e, quanto aos seus direitos, "se afiguram agora apenas poderes que dispõe para o desempenho do seu papel na comunidade". Ibid. p. 13. Quanto às 
particularmente, o art. 187 do atual Código Civil $^{277}$, que faz referência à ilicitude do exercício de direitos subjetivos ${ }^{278}$ que excedem limites impostos pela boa-fé, bons costumes, ou finalidade econômica ou social. ${ }^{279}$ Aqui, a boa-fé se une à teoria do abuso do direito para valorar o comportamento das partes, limitando o exercício discricionário de um direito individual. Assim, no contrato ora analisado, a boa-fé é fortemente violada na sua vertente integrativa e, sob a luz do ordenamento vigente, a Corte de Veneza poderia reprimir o abuso 280 cometido por Shylock a fim de impedir que Antônio cedesse a libra de carne.

A necessidade de prever uma hipótese legal de abuso surge com o objetivo de reprimir aqueles atos que, ainda que tecnicamente de acordo com a

relações comerciais, "a tentativa de alcançar a segurança jurídica não pode passar pela imposição de um microssistema imune aos mandamentos constitucionais Aponta-se, então, como saída, a mudança de perspectiva: mais do que a busca incessante pela criação de um novo Código Comercial, como forma de regular específica e positivamente as relações jurídicas em busca da garantia das relações empresariais, o que se deve ter em mente é o pensamento sistemático que parta da Constituição e não se feche na existência de um setor ou de um microssistema isolado, permitindo-se a incidência dos valores e princípios constitucionais também nas relações entre empresários." SOARES, Felipe Ramos Ribas; MATIELI, Louise Vago; DUARTE, Luciana da Mota Gomes de Souza. Unidade do ordenamento na pluralidade das fontes: uma crítica à teoria dos microssistemas. In: SCHREIBER, Anderson; KONDER, Carlos Nelson. Direito Civil Constitucional. São Paulo: Atlas. 2016. p. 85

${ }^{277}$ Quanto a vertente criativa da boa-fé representada no art. 422 do Código Civil, não houve violação, uma vez que os deveres secundários de conduta, como lealdade, transparência, cuidado e confidencialidade, foram mantidos. Em relação ao art. 113 também do Código Civil, entende-se não haver violação da função interpretativa da boa-fé, vez que nenhum padrão comportamental foi diretamente violado. Por essa razão, melhor se encaixa a função integrativa da boa-fé, que lhe propõe a identificar o exercício abusivo de um direito.

${ }^{278}$ Segundo Léon Duguit, a diferenciação entre direito objetivo e subjetivo se dá da seguinte maneira: direito subjetivo é um poder do indivíduo que vive em sociedade que permite a obtenção do objeto social que pretende, quando o motivo determinante da sua vontade é considerado legítimo pelo direito objetivo. Este, por sua vez, é a norma de conduta que se impõe aos indivíduos que vivem em sociedade, sendo garantia do interesse comum e cuja violação determina reação coletiva contra o agente que a praticou. DUGUIT, Léon. Op. cit., p. 7.

${ }^{279}$ Há clara inspiração no art. 334 do Código Civil Português: "É ilegítimo o exercício de um direito, quando o titular exceda manifestamente os limites impostos pela boa-fé, pelos bons costumes ou pelo fim social ou econômico desse direito".

${ }^{280} \mathrm{O}$ abuso de poder é caracterizado quando se está diante de uma situação jurídica onde o exercício do direito se dá por meio de modalidades diferentes daquelas que derivam da função da situação subjetiva. Segundo Pietro Perlingieri, no entanto, o excesso de poder, diferentemente do abuso, "pode ser traduzido, outrossim, em um poder que, apesar de limitado, é de qualquer modo exercício além do limite consentido, isto é, à falta de uma objetiva justificação jurídica. O excesso, portanto - ao contrário do abuso - não postula uma relação com a função da situação.” PERLINGIERI, Pietro. Op. cit., p. 122 123. 
lei, deixam de refletir a intenção do legislador. ${ }^{281} \mathrm{O}$ que se busca, portanto, ao caracterizar o abuso do direito, é impedir o comportamento, diante de determinadas situações jurídicas, que seja contrário aos princípios do Direito Civil Constitucional. Para isso, diante da prática de um direito subjetivo ${ }^{282}$, busca-se valorar a conduta, almejando a validação do exercício diante da conformidade ou não com a finalidade que o ordenamento jurídico pretende para aquela situação.

Pode-se afirmar que sob a perspectiva Civil-Constitucional que hoje influencia o ordenamento brasileiro, a releitura de "O Mercador de Veneza" significa abordar o contrato a partir dos princípios pós-modernos. Isso não significa, no entanto, a superação dos dogmas clássicos e sim a mitigação e convivência das principiologias antigas e atuais, em equilíbrio graças ao paradigma da essencialidade. Deste modo, os princípios da boa-fé, função social e equilíbrio econômico são ferramentas que, em combinação com os dogmas clássicos mitigados (e não excluídos), a fim de funcionalizar a liberdade contratual a caminho da concretização dos objetivos sociais da Constituição.

Assim como Equity caminha lado a lado com a rigidez da Common Law para superar a "insuficiência ética"283 da lei europeia, o Direito Constitucional traça sua trajetória junto ao Direito Civil, incorporando os princípios da Constituição de 1988 para além das relações entre Estado e cidadão, nas relações

\footnotetext{
${ }^{281}$ Ou que violam o "espírito da lei”. TEPEDINO, Gustavo; BARBOSA, Heloísa Helena; MORAES, Maria Celina Bodin de. Código Civil Interpretado: Conforme a Constituição da República. $2^{\mathrm{a}}$ ed. Rio de Janeiro: Renovar, 2011. v. 1. p. 345. "No Brasil, O CC 1916 não contemplava expressamente a figura do abuso de direito. Referia-se, todavia, ao exercício regular do direito como hipótese em que o prejuízo causado a outrem não era indenizável (art. 160). Dessa referência extraída a doutrina, a contrário sensu, interpretava que o exercício irregular (rectius: abusivo) de um direito era coibido, gerando o dever de indenizar." TEPEDINO, Gustavo, BARBOSA, Heloísa Helena; MORAES, Maria Celina Bodin de. Código Civil Interpretado: Conforme a Constituição da República. $2^{\mathrm{a}}$ ed. Rio de Janeiro: Renovar, 2011. v. 1. p. 346.

282 No caso de Shylock, temos um direito subjetivo, decorrente de uma violação de um direito (inadimplemento contratual). No entanto, não somente deve observar os limites do ordenamento o direito subjetivo, mas também o direito potestativo, que são aqueles concedidos pela lei e não precedidos de violação.

${ }^{283}$ Expressão utilizada por José Alexandre Guerreiro. GUERREIRO. José Alexandre Tavares. Equidade em Shakespeare. In: ALQUÉRES, José Luiz; NEVES, José Roberto de Castro (Org.). Ele, Shakespeare, visto por nós, os advogados. Rio de Janeiro: Janeiro, 2017. p. 145.
} 
interpessoais. ${ }^{284} \mathrm{O}$ objetivo foi suprir carência principiológica do ordenamento em comportamento semelhante à mitigação do ius strictum ${ }^{285}$ europeu. $^{286}$ Do mesmo modo que "Shakespeare trouxe ao teatro toda a problemática da coexistência entre ius strictum e ius aequum, sendo que um não repele o outro" ${ }^{287}$, o ordenamento brasileiro no que tange o Direito Obrigacional, é composto por princípios pós-modernos de natureza constitucional, o que não significa que os dogmas clássicos foram de todo substituídos. ${ }^{288}$

${ }^{284}$ Chegara-se a um momento em que a evolução da lei se tornara imprescindível, uma vez que o comércio marítimo se intensificara a partir do final do século XV e com isso fomentou-se também as trocas comerciais e a necessidade de integrar os usos e costumes à ordem jurídica. A isto, soma-se o fato de que a partir da Reforma, em 1517, começou a construção de um ser humano do ponto de vista antropológico, nas múltiplas facetas espirituais e sociais. Ibid. p. 146.

285 "Strict law" ou direito estrito.

${ }^{286}$ Pode-se exemplificar evolução do direito contratual partindo da literalidade da lei inglesa e do direito civil clássico brasileiro em direção à equidade e aos princípios do Direito Civil Constitucional utilizando duas peças shakespearianas: "Ricardo II" e "O Mercador de Veneza". A primeira, peça histórica, se passa em uma sociedade feudal onde vigoravam os votos tipicamente medievais de fidelidade eterna do cumprimento do contrato. A segunda, por outro lado, situada em um ambiente pós-feudalismo, atribui ao contrato noções pós-modernas da relação entre contratantes, mitigando a obrigatoriedade estrita do pacto.

${ }_{287}$ GUERREIRO. José Alexandre Tavares. Op. cit., p. 151.

${ }^{288}$ Tal como se posiciona o Doge de Veneza ao afirmar que os dois seguimentos da justiça (ius strictum e ius aequum) devem ser parte integrante do direito, também devem os dogmas antigos permanecer em convivência, ainda que mitigados, com os princípios do Direito Constitucional contemporâneo. Ibid. p. 151. 


\section{CONCLUSÃO}

Por que Shakespeare importa para o Direito? ${ }^{289}$ É compreensível o questionamento acerca da contribuição pragmática da Literatura para o Direito: se a arte literária se traduz na manifestação humana do uso estético da linguagem $^{290}$ e a elocução jurídica busca legitimidade em critérios de racionalidade, o que teriam os grandes nomes literários a ensinar para os juristas na aplicação prática da lei?

Parte-se do pressuposto de que a Literatura, apesar de ser uma expressão artística, busca seus fundamentos na natureza do homem e traduz suas descobertas na poesia da linguagem com o objetivo de despir a essência humana frente ao mundo. O Direito não trabalha de modo diferente, procurando seus alicerces de legitimidade no próprio mundo do homem e transpondo seus achados na racionalidade da lei, com o desígnio de tornar transparente o indivíduo frente ao Estado e a sociedade. Nessa tênue afinidade habita o perigo. ${ }^{291}$

A Literatura quer seduzir. ${ }^{292}$ Há um objetivo por trás da exposição da

\footnotetext{
${ }^{289}$ Reconhecida a evolução do Direito Civil Constitucional de modo semelhante com o que ocorreu no direito europeu com a construção da equidade e estudada esta evolução por meio da obra Shakespeariana, resta influir como o estudo da literatura pode verdadeiramente influenciar o sistema jurídico para além da mera ilustração histórica.

290 “A Língua é então, praticamente, a linguagem menos a Fala: é, ao mesmo tempo, uma instituição social e um sistema de valores. Como instituição social, ela não é absolutamente um ato, escapa a qualquer premeditação; é a parte social da linguagem; o indivíduo não pode, sozinho, nem criá-la nem modificá-la (...) Como sistema de valores, a Língua é constituída por um pequeno número de elementos de que cada um é, ao mesmo tempo, um vale-por e o termo de uma função mais ampla onde se colocam, diferencialmente, outros valores correlativos". BARTHES, Roland. Elementos de semiologia. $15^{\mathrm{a}}$ ed. Tradução de Izidoro Blikstein. São Paulo: Cultrix, 2003. p. 17-18.

291 Ainda que que o direito e a Literatura se munam de técnicas semelhantes para catalogar o gênio humano e sua natureza, seus propósitos, ainda que soem parecidos, são extremamente distintos.

292 Essa sedução se diferencia da sedução da "prudência" e "oportunidade" persuasiva do discurso jurídico sofista, na medida em que é, além de artificiosa, repleta de mistérios e penumbras propositais que querem dar "asas à imaginação". Essa distinção de técnica de sedução é importante, pois, segundo Luiz Alfredo Garcia-Roza os sofistas já se valiam de instrumentos da linguagem para seduzir: "Os
} 
essência humana nua e crua, que é o fascínio. A literatura não pode expor de todo o que quer dizer, pois se colocasse seu objeto às claras a mágica da imaginação desapareceria. ${ }^{293} \mathrm{O}$ Direito quer regular. Sua concretização só pode ocorrer se for aplicado com clareza. O Direito não pode se dar "o luxo" de ser misterioso e obscuro, pois isso vai contra seus propósitos regulatórios. ${ }^{294}$

A linguagem jurídica deve ser sempre franca ${ }^{295}$. É perigoso o uso de eufemismos ou redundâncias que se afastem da "verdade"296, ainda que áspera, da lei. Para o Direito, "ler nas entrelinhas" é arriscado. Quando as decisões judiciais ${ }^{297}$ se deixam envolver demais por um caráter literário os resultados

termos que melhor se aplicariam aos sofistas seriam 'prudência' e 'oportunidade'. Jogando com a contingencia dos fatos, os sofistas permanecem na horizontalidade dos acontecimentos, não pretendendo com a técnica da palavra nada mais do que a persuasão. Para eles, a palavra é um instrumento de persuasão e não um meio de se chegar à verdade." GARCIA-ROZA, Luiz Alfredo. Palavra e Verdade: $\mathrm{Na}$ filosofia antiga e na psicanálise. $5^{\mathrm{a}}$ ed. Rio de Janeiro: Zahar, 2005. p. 53.

${ }^{293}$ Por isso seu empirismo se limita a lançar mão de uma "moral da história" ao final de uma fábula, mas evita-se reduzir as palavras à literalidade de modo que não percam seu mistério.

${ }^{294}$ Relembrando a famosa frase do filósofo Ludwig Wittgenstein, "tudo o que pode ser dito, pode ser dito com clareza".

${ }^{295}$ Um exemplo de franqueza nas decisões judiciais ocorreu em Jacobellis vs. Ohio, onde o juiz Potter Stewart da Suprema Corte norte-americana será sempre lembrado por ter dito que não conseguiria descrever pornografia, mas que a reconhecia quando a via e, com esse fundamento, afastou no caso em questão a hipótese pornográfica: "But I know it when I see it, and the motion picture involved in this case is not that". Tradução livre: Eu sei o que é quando vejo e o filme neste caso não é isso. $<$ https://www.law.cornell.edu/supremecourt/text/378/184> Acesso em 22 out. 2017. Segundo Richard Posner, a sinceridade dessa decisão é o oposto das evasões das decisões judiciais de hoje, que fazem uso de um discurso que se esquiva de dizer a verdade "nua e crua". Por isso, a franqueza no discurso desta decisão, segundo Posner, teria feito pela discussão legal da pornografia aquilo que George Orwell fez pela discussão literária da violência revolucionária. POSNER, Richard A., "Law and Literature: A Relation Reargued," Virginia Law Review, Virginia, n. 8, nov. 1986. v. 72. p.1391. Aqui, não se vai contra a subjetividade decisionista utilizada no livre convencimento do julgador e sim da extrapolação da liberdade interpretativa da lei, ao ponto em que a decisão passa a adotar características discricionárias. ${ }^{296}$ Para John Searle a pergunta "O que é a verdade?" está no centro da filosofia. SEARLE. John R. Mente, Linguagem e Sociedade: Filosofia no mundo real. Tradução de F. Rangel. Rio de Janeiro: Rocco, 2000. p. 147. Aqui, o vocábulo tem o propósito de enunciar tudo aquilo que circunda o texto legal e que envolve o julgador no momento da decisão. Em especial, refere-se às situações de lacuna, onde o juiz se vê inclinado a interpretar o enunciado legal além dos limites jurídicos, mesmo quando uma interpretação razoável não é possível. Falta-se com a franqueza para encobrir a limitação legal, ao invés de admiti-la (como correta e francamente fez o juiz Potter Stewart em Jacobellis vs. Ohio, 1964.) "Surge uma lacuna na lei quando ela não regulamenta claramente algum caso específico. A falta de clareza pode decorrer de vagueza, ambiguidade, contradição ou algum fenômeno linguístico análogo.” SHECAIRA, Fábio P.; STRUCHINER, Noel. Teoria da argumentação jurídica. Rio de Janeiro: ed. PUC-Rio: Contraponto, 2016. p. 104.

${ }^{297}$ Se há divergência entre doutrinadores a respeito da questão da contribuição da Literatura para a interpretação de textos legais, não resta dúvidas que, no caso das questões judiciais, a literatura tem muito a ensinar: "I shall argue, among other things, that the study of literature has little to contribute to the interpretation of statues and constitutions but that it has something, perhaps a great deal, to contribute 
podem ser prejudiciais, sobretudo no que toca a aplicação de princípios e postulados hermenêuticos na busca pela justiça. ${ }^{298}$

Atualmente, a ponderação jurisprudencial de princípios repercute insegurança jurídica, revelando situações de absoluta incerteza. ${ }^{299}$ Segundo Eros Grau, a "promiscuidade" 300 dos valores é resultado das ponderações que os revalorizam reiteradamente feita pelos juízes com o objetivo de impor suas crenças por meio de discricionariedade ${ }^{301}$. Assim sendo, o poder judiciário se converte em um "produtor de inseguranças"302, semelhante ao papel desempenhado pela figura de autoridade da $\mathrm{Corte}^{303} \mathrm{em}$ "O Mercador de

to the understanding and the improvement of judicial opinions.” POSNER, Richard A. Op. cit., p. 1351. Tradução livre: Eu sustento, entre outras coisas, que o estudo da literatura tem pouco a contribuir para a interpretação de estatutos e constituições, mas que tem algo, senão muito, a contribuir para o entendimento e melhoramento de decisões judiciais.

${ }^{298}$ Essa busca pela justiça ocorre principalmente na utilização do postulado da razoabilidade como busca pela equidade. Segundo Humberto Ávila, "a razoabilidade serve de instrumento metodológico para demonstrar que a incidência da norma é condição necessária, mas não suficiente para a sua aplicação. Para ser aplicável, o caso concreto deve adequar-se à generalização da norma geral. A razoabilidade atua na interpretação das regras gerais como decorrência do princípio da justiça (Preâmbulo e art. $3^{\circ}$ da CF)" ÁVILA, Humberto. Teoria dos Princípios: da definição à aplicação dos princípios jurídicos. $14^{\mathrm{a}}$ ed. São Paulo: Malheiros, 2013. p. 176.

${ }^{299}$ No HC 82.424. RS os ministros Marco Aurélio e Gilmar Mendes utilizaram a proporcionalidade para analisar a colisão da liberdade de expressão e da dignidade do povo judeu, alcançando decisões opostas. O primeiro optou por afirmar não ser razoável, adequado ou necessário restringir a liberdade de expressão pela publicação de livro antissemita enquanto o segundo considerou a restrição à liberdade de expressão medida adequada, necessária e proporcional. STF, HC 82.424, Rel. Min. Moreira Alves, Brasília, 03 mar. 2004.

${ }^{300}$ Devido à emersão de uma "tirania de valores" é possível eleger um determinado valor de forma que este sobressaia a custo de todos os outros, ainda que não lhe sejam opostos. GRAU, Eros. Roberto. Ensaio e Discurso sobre a Interpretação/ Aplicação do Direito. $4^{\mathrm{a}}$ ed. São Paulo: Malheiros, 2006. p. 33. ${ }^{301}$ A discricionariedade é o reflexo da tendência de trazer o "ativismo judicial" para todo o ordenamento brasileiro. Essa expressão consta no anteprojeto de Código Brasileiro de Processo Coletivo (Projeto de Lei $\mathrm{n}^{\mathrm{o}} 5.139 / 2009$ ) como princípio norteador. Ainda que o objetivo dos princípios seja flexibilizar a aplicação rígida da lei, criando um norte a ser seguido pelos intérpretes, o abuso principiológico acarreta em insegurança jurídica, $\mathrm{O}$ uso dos princípios e postulados para chegar a uma decisão "justa" acaba por tomar "vida própria", preterindo a própria letra da lei na escolha por fundamentação. Esta tendência do ordenamento jurídico brasileiro de afastar a rigidez legal e caminhar para um sistema principiológico é semelhante ao que ocorreu na Corte de Veneza na busca por justiça.

${ }^{302}$ Expressão utilizada por Eros Grau. GRAU. Eros, Roberto. Op. cit., p. 16. Esta insegurança fica exposta pela memorável frase de Shylock que se volta contra a possível negativa da garantia que lhe era devida, sem haver embasamento normativo para tanto: "If you deny me, fie upon your law! There is no force in the decrees of Venice." "O Mercador de Veneza": Ato IV, Cena I.

${ }^{303}$ Ainda que o Doge não tenha feito uso de princípios e postulados como conhecemos hoje, utilizou um juízo de ponderação, proporcionalidade e razoabilidade implícito para prever de que maneira poderia chegar ao resultado que pretendia desde o início do julgamento, qual seja, a inaplicabilidade da garantia, por não a considerar razoável. As primeiras palavras do Doge para Shylock deixam claro sua posição de parcialidade. Ele claramente era favorável a Antônio: "Shylock, o mundo pensa, e eu também como 
Veneza".

De acordo com Lenio Streck, a problemática e a complexidade do quadro principiológico aumenta ainda mais diante do amplo conjunto de princípios póspositivistas. ${ }^{304}$ É essa mesma proliferação de princípios, na busca pela autonomia do Direito, que acaba por enfraquecer a mesma, na medida em que os discursos principiológicos transparecem cada vez mais uma escusa para a ultrapassagem dos limites semânticos do texto constitucional. ${ }^{305}$ Este fenômeno é chamado de "panprincipiologismo".306

De modo semelhante ao que fez o Doge ${ }^{307}$, os Tribunais se valem da enunciação ${ }^{308}$ inapropriada de postulados para justificar o resultado pretendido. Parte-se do resultado almejado e busca-se o fundamento legal de cunho

todos, que tencionas persistir nessas provas de crueldade somente até à última hora do processo, depois do que, se diz, irás mostrar-nos doçura e consideração mais raras do que esse gesto de crueldade inculca. Em vez de, agora, a multa reclamares - uma libra de carne deste pobre mercador - não somente vais dizer-nos que o castigo dispensas, como, ainda, levado pelo amor e o sentimento de humanidade, perdoarás metade da dívida (...) todos esperamos uma resposta branda, judeu." "O Mercador de Veneza": Ato IV, Cena I.

304 Segundo Streck, torna-se extremamente difícil identificar se se está diante de um princípio constitucional, infraconstitucional ou de um enunciado dos "velhos princípios gerais do direito". STRECK, Lenio Luiz. Verdade e Consenso: Constituição, hermenêutica e teorias discursivas. $4^{\mathrm{a}}$ ed. Rio de Janeiro: Saraiva, 2011. p. 538.

305 'Esse 'panprincipiologismo' faz com que, a pretexto de aplicar princípios constitucionais, haja uma proliferação descontrolada de enunciados para resolver determinados problemas concretos, muitas vezes ao alvedrio da própria legalidade constitucional." Ibid. p. 50.

306 ' $\mathrm{Na}$ 'ausência' de 'leis apropriadas', o intérprete 'deve' lançar mão dessa ampla principiologia, sendo que, na falta de um princípio aplicável, o próprio intérprete pode cria-lo. Em tempos de 'densa principiologia' e 'textura aberta', tudo isso propicia a que se dê um novo status ao velho non liquet. Isto é, os limites do sentido e o sentido dos limites do aplicador já não estão na Constituição, enquanto 'programa normativo-vinculante', mas sim, em um conjunto de enunciados criados ad hoc (e com funções $a d$ hoc), que, travestidos de princípios, constituem uma espécie de 'supraconstitucionalidade'." Ibid. p. 539.

${ }^{307}$ Ao final, a razoabilidade que o Doge pretendia, na procura pela equidade, foi empregada, mas ficou mascarada por trás da aplicação literal do texto da lei, que tornou impossível a cobrança da carne, uma vez que impedia que também se retirasse sangue e também proibia que tirasse pouco mais ou pouco menos que uma libra. Essa atitude evidencia o que, segundo Bourdieu, consiste em "tirar o máximo partido da elasticidade da lei e mesmo das suas contradições, das suas ambiguidades ou das suas lacunas", uma vez que, "os juristas e juízes dispõem todos, embora em graus muito diferentes, do poder de explorar a polissemia ou a anfibologia das fórmulas jurídicas”. BOURDIEU, Pierre. Op. cit., p. 224. 308 "O poder simbólico como poder de construir o dado pela enunciação, de fazer ver e fazer crer, de confirmar ou de transformar a visão de mundo e, deste modo, a ação sobre o mundo". Significa que a relação é determinada entre aqueles que "exercem o poder e os que lhe estão sujeitos", o que transforma o poder simbólico em "uma forma transformada, quer dizer, irreconhecível, transfigurada e legitimada". Ibid. p. 14-15. 
principiológico capaz de justificá-lo, quando dever-se-ia fazer o contrário. ${ }^{309}$ Princípios e postulados ${ }^{310}$ deveriam ser utilizados para chegar ao resultado justo e não como instrumento de escusa posterior que justifique a "justiça" 311 no caso empregada. Sobretudo os postulados da proporcionalidade, razoabilidade e da ponderação $^{312}$ se tornaram os utensílios mais empregados nesta estratégia. ${ }^{313}$

Outra questão delicada diante da exorbitância principiológica contida nas decisões é a referência demasiada à dignidade da pessoa humana. ${ }^{314}$ Ao longo dos anos que seguiram o advento do Direito Civil Constitucional este princípio se tornou banalizado pela carência de sua adequada densificação. ${ }^{315}$ A dignidade

\footnotetext{
${ }^{309}$ Ao invés da busca por um resultado, argumenta-se em favor de uma conclusão pré-existente. Para Noel Struchiner e Fábio P. Shecaira, argumentar é: "ato de produzir argumentos. Produzir um argumento é apresentar razões em defesa de uma conclusão”. SHECAIRA, Fábio P.; STRUCHINER, Noel. Op. cit., p. 11.

${ }^{310} \mathrm{O}$ grande problema também reside na diferenciação entre princípios e postulados, uma vez que estes últimos consistem em critérios de aplicação de outras normas. Os postulados não são normas finalísticas e sim metódicas, pois estruturam racionalmente a aplicação das normas. Segundo Humberto Ávila, "os postulados funcionam diferentemente dos princípios e das regras. A uma, porque não se situam no mesmo nível: os princípios e as regras são normas objeto da aplicação; os postulados são normas que orientam a aplicação de outras." ÁVILA, Humberto. Op. cit., p. 143-144.

${ }^{311}$ Leia-se "discricionariedade".

312 O problema, segundo Lenio Streck é: "é possível chegar às mais diversas respostas, ou seja, casos idênticos acabam recebendo decisões diferentes, tudo sob o manto da "ponderação" e da proporcionalidade (ou da razoabilidade)". Segundo o autor, a ponderação, a razoabilidade e a proporcionalidade se transformaram em enunciados performativos. Streck explica que a expressão "performativa" faz emergir a significação do enunciado com a simples enunciação do mesmo e, a partir disto, não pode mais receber críticas ou ser contestado. Quando a ponderação de valores, a proporcionalidade e a razoabilidade são submetidos ao uso performativo tem um forte poder de violência simbólica. Streck, Lenio Luiz. Op. cit., p. 55. Segundo Pierre Bourdieu, o poder simbólico é um poder invisível, "o qual só pode ser exercido com a cumplicidade daqueles que não querem saber que lhe estão sujeitos ou mesmo que o exercem" e que procuram construir uma realidade, semelhante ao que fazem a arte, a religião e a língua. BOURDIEU, Pierre. O Poder Simbólico. $7^{\mathrm{a}}$ ed. Trad. Fernando Tomaz. Rio de Janeiro: Bertrand Brasil, 2004. p. 8-9.

${ }^{313}$ A utilização inadequada destes três postulados na interpretação e aplicação das normas jurídicas ocorre quando servem como princípios justificadores da decisão judicial, como normas objeto finalísticas, ao invés de servir seu verdadeiro propósito, que é o de instrumento na aplicação de outras normas. Com isto, decisões são equivocadamente fundamentadas pelo "princípio da razoabilidade", pelo "princípio da proporcionalidade" e pelo "princípio da ponderação" que ganham sentido próprio na discricionariedade judicial.

${ }^{314}$ Segundo José Alexandre Guerreiro, no direito europeu, "a equidade, na vida privada, entre cidadãos, tem sua correspondência com as exigências sociais do Estado". Da mesma maneira, no Brasil, a imposição de limites à atuação das relações interpessoais foi uma exigência social do Estado e, pelo fundamento na dignidade da pessoa humana traz-se nova ótica para a aplicação do direito entre cidadãos. GUERREIRO, José Alexandre Tavares. Op. cit., p. 149.

315 Com o Direito Civil Constitucional, as situações jurídicas subjetivas patrimoniais passaram a ser tuteladas, não em si mesmas, mas na medida em que realizassem os valores constitucionais extrapatrimoniais. Substitui-se "o patrimônio pela pessoa humana no vértice dos valores tutelados pela
} 
da pessoa humana virou um "coringa jurídico" a ser utilizado de prontidão nas fundamentações. Tornou-se uma "carta na manga" dos juristas que fazem uso do conceito para justificar qualquer tipo de decisão com um mero artifício retórico. ${ }^{316}$

Está-se diante da utilização desnecessária da dignidade da pessoa humana como fundamento decisório, em evidente abuso da invocação do referido princípio, como se fosse, nas palavras do Ministro Dias Toffoli, "uma panaceia para todos os males." ${ }^{317}$ Segundo Toffoli, é preciso pôr fim à "principiolatria" desenfreada que culmina no uso exacerbado de um princípio tão importante. Deve-se evitar que este valor central do Direito Civil Constitucional se torne "um tropo oratório que tende à flacidez absoluta". 318

Evitar o uso desnecessário deste princípio não é impossível. ${ }^{319}$ Este trabalho procurou reconstruir a peça Shakespeariana em torno da questão central

Constituição. O processo de despatrimonialização do direito civil é fortemente relacionado com o fenômeno da repersonalização, que postula, em síntese, a centralidade da pessoa humana considerada em concreto em detrimento do sujeito do direito abstrato". CASTRO, Julia Ribeiro de; SOUZA, Thiago Andrade. A dicotomia entre as situações existenciais e as situações patrimoniais. In: SCHREIBER, Anderson; KONDER, Carlos Nelson. Direito Civil Constitucional. São Paulo: Atlas. 2016. p.162.

316 "Dignidade da pessoa humana acabou por ganhar, assim, a propriedade de servir a tudo. De ser usado onde cabe com acerto pleno, onde convém com adequação discutível e onde definitivamente não é o seu lugar. Empobreceu-se. Esvaziou-se. Tornou-se um tropo oratório que tende à flacidez absoluta." VILLELA, João Baptista. Variações impopulares sobre a dignidade da pessoa humana. Superior Tribunal de Justiça: Doutrina. Edição comemorativa, 20 anos, Distrito Federal, 2009. p. 562

317 ،...considero haver certo abuso retórico em sua invocação nas decisões pretorianas, o que influencia certa doutrina, especialmente de Direito Privado, transformando a conspícua dignidade humana, esse conceito tão tributário das Encíclicas papais e do Concílio Vaticano II, em verdadeira panaceia de todos os males." Segundo o Ministro, o descrédito deste princípio ocorre de modo semelhante ao processo de deformação da cláusula geral da boa-fé na jurisprudência francesa, pois "se para tudo se há de fazer emprego desse princípio, em última análise, ele para nada servirá”. STF, RE 363.889, Rel. Min. Dias Toffoli, Brasília, 02 jun. 2011.

318 “Alguém acha que deve ter melhores salários? Pois que se elevem: uma simples questão de dignidade da pessoa humana. Faltam às estradas condições ideais de tráfego? É a própria dignidade da pessoa humana que exige sua melhoria. O semáforo desregulou-se em consequência de chuvas inesperadas? Ora, substituam-no imediatamente. A dignidade da pessoa humana não pode esperar. É ela própria, a dignidade da pessoa humana, que se vê lesada quando a circulação viária das cidades não funciona impecavelmente 24 horas por dia. O inquilino se atrasou com os alugueres? Despejem-no o quanto antes: Fere a dignidade da pessoa humana ver-se o locador privado, ainda que por um só dia, dos direitos que a locação lhe assegura." VILLELA, João Baptista. Op. cit., p. 562.

319 À primeira vista, ao se deparar com a disputa entre Shylock e Antônio, o jurista pode se sentir inclinado a invocá-lo, mas não é preciso preterir outros fundamentos legais pela simples razão da dignidade "pular mais forte" no peito do jurista contemporâneo. 
polêmica de "O Mercador de Veneza" chegando à decisão final sem ter como fundamento central a dignidade humana. ${ }^{320} \mathrm{O}$ que se descobriu foi que aquilo que os juristas podem aprender com uma história fictícia situada no séc. XIV, escrita por um dramaturgo do séc. XVI não é pouco. É importante não se deixar enganar por uma leitura pueril dos clássicos, pois eles têm muito a lecionar para aqueles capazes de transpor seus ensinamentos para a atualidade e aplicá-los ao mundo contemporâneo. ${ }^{321}$

Se a disputa entre Shylock e Antônio pôde chegar a um mesmo resultado sem invocar a dignidade da pessoa humana, é possível solucionar conflitos contemporâneos sem fazer uso desnecessário de um princípio de suma importância, de modo a não contribuir para o seu enfraquecimento. Também é necessário valer-se corretamente dos postulados da ponderação, razoabilidade e proporcionalidade no caminho pela "justiça", sem que sirvam de desculpa para uma decisão discricionária da Corte.

Já fora o tempo no qual restavam dúvidas acerca da contribuição da Literatura para o Direito. Elas não podem mais existir. É perigoso negar a semelhança entre estes dois institutos das "ciências" humanas na medida em que as afinidades se desenvolveram para além da comparação teórica e refletem diretamente no plano prático. Talvez não seja aconselhável seguir os conselhos de William Shakespeare literalmente ${ }^{322}$, mas é possível extrair de suas obras conclusões significativas sobre o mundo dos homens, e a partir daí moldar os aparatos necessários na construção e evolução do formidável sistema regulatório das relações humanas que é o Direito.

\footnotetext{
320 Primeiro, foi possível reconstruir o julgamento veneziano à luz da perspectiva econômica do ordenamento jurídico brasileiro sem a necessidade de invocar princípio algum. Posteriormente, chegouse ao mesmo resultado fazendo uso do paradigma da essencialidade, ponderando os dogmas clássicos da relação obrigacional e os princípios pós-modernos do Direito Civil Constitucional, sem que fosse preciso invocar a dignidade humana para livrar Shylock de uma garantia abusiva.

321 "O rendimento máximo da leitura dos clássicos advém para aquele que sabe alterná-la com a leitura de atualidades numa sábia dosagem”. CALVINO, Italo. Por que ler os clássicos. $2^{\mathrm{a}}$ ed. Trad. Nilson Moulin. São Paulo: Companhia das Letras, 2007. p. 14-15.

322 "The first thing we do, let's kill all the lawyers". "Henrique IV", Parte II, Ato IV, Cena II. Grifo meu. Tradução livre: A primeira coisa que faremos: matar todos os advogados!
} 


\section{BIBLIOGRAFIA}

ANDRADE, Darcy Bessone de Oliveira. Do direito do comerciante à renovação do arrendamento. Minas Gerais: Imprensa Oficial de Minas Gerais, 1940. 201 p.

ANTUNES. José A. Engrácia. Direito dos Contratos Comerciais. Coimbra: Almedina, 2009. 875 p.

ALQUÉRES, José Luiz; NEVES, José Roberto de Castro (Org.). Ele, Shakespeare, visto por nós, os advogados. Rio de Janeiro: Janeiro, 2017. 191 p.

ARAÚJO, Fernando. Teoria Econômica do Contrato. Coimbra: Almedina, 2007. $1340 \mathrm{p}$.

ARISTÓTELES. Ética a Nicômaco. Tradução de Edson Bini. $2^{\mathrm{a}}$ ed. São Paulo: EDIPRO, 2007. 319 p.

ÁVILA, Humberto. Teoria dos Princípios: da definição à aplicação dos princípios jurídicos. 14a ed. São Paulo: Malheiros, 2013. 215 p.

AZEVEDO. Álvaro Vilaça. Teoria Geral das Obrigações e Responsabilidade Civil. 12 ed. Atlas: São Paulo, 2011. 331 p.

AZEVEDO, Antônio Junqueira de. Negócio Jurídico: existência, validade e eficácia. $4^{\circ}$ ed. Rio de Janeiro: Saraiva, 2002. 172 p.

BANDEIRA, Paula Greco. Contratos Aleatórios no Direito Brasileiro. Rio de Janeiro: Renovar, 2010, 272 p. 
BARBOSA, Denis Borges; CORREIRA, Arícia Fernandes. Direito e literatura: estudos de teoria do direito. Disponível em

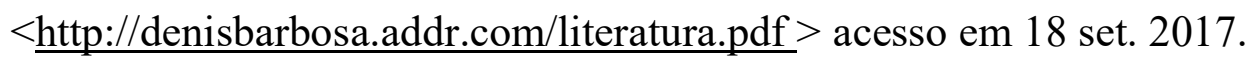

BARBOSA, Pedro Marcos Nunes. A autonomia negocial nos contratos e impactos de natureza existencial: Alguns tópicos Polêmicos. Revista Escola da Magistratura Regional Federal 2a Região. Rio de Janeiro, v. 14. p. 179 - 202, nov. 2010.

BARROSO, Luís Roberto. Shakespeare e seu tempo. In: ALQUÉRES, José Luiz; NEVES, José Roberto de Castro (Org.). Ele, Shakespeare, visto por nós, os advogados. Rio de Janeiro: Janeiro, 2017. p. 35 - 62.

BARTHES, Roland. Elementos de semiologia. $15^{\mathrm{a}}$ ed. Tradução de Izidoro Blikstein. São Paulo: Cultrix, 2003. 116 p.

BECCARIA, Cesare. Dos delitos e das penas. $3^{\mathrm{a}}$ ed. Tradução de J. Cretella Jr. e Agnes Cretella. São Paulo: Revista dos Tribunais, 2006. 127 p.

BITTAR, Carlos Alberto. Contratos comerciais. $6^{\text {a }}$ ed. Rio de Janeiro: Forense Universitária, 2010. 209 p.

BIX, Brian H. Contract Law: Rules, Theory, and Context. Nova Iorque: Cambridge University Press, 2012. 202 p.

BOBBIO, Norberto. Teoria do Ordenamento Jurídico. Tradução de Maria Celeste C. J. Santos. 6 $6^{\mathrm{a}}$ ed. Brasília: Universidade de Brasília, 1995. 184 p. 
BOURDIEU, Pierre. O Poder Simbólico. $7^{\mathrm{a}}$ ed. Tradução de Fernando Tomaz. Rio de Janeiro: Bertrand Brasil, 2004. 322 p.

BRYSON, Bill. Shakespeare: $O$ mundo é um palco. Tradução de José Rubens Siqueira. Companhia das letras: São Paulo, 2008. 199 p.

CALVINO, Italo. Por que ler os clássicos. $2^{\mathrm{a}}$ ed. Trad. Nilson Moulin. São Paulo: Companhia das Letras, 2007. 279 p,

CASTRO, Flávia Lages de. História do Direito: Geral e Brasil. $8^{\mathrm{a}}$ ed. Rio de Janeiro: Lumen Juris, 2011. 570 p.

CASTRO, Julia Ribeiro de; SOUZA, Thiago Andrade. A dicotomia entre as situações existenciais e as situações patrimoniais. In: SCHREIBER, Anderson; KONDER, Carlos Nelson. Direito Civil Constitucional. São Paulo: Atlas. 2016. p. $157-188$.

CHAMOUN, Ebert Viana. Instituições de Direito Romano. $3^{\mathrm{a}} \mathrm{ed}$. Rio de Janeiro: Revista Forense, 1957. 531 p.

CLARKE. Harold Goddard. The meaning of Shakespeare. $5^{\mathrm{a}}$ ed. v 1. Chicago: University of Chicago Press, 1965. 393 p.

DIDIER Jr., Fredie. Curso de Direito Processual Civil. 13 ${ }^{\mathrm{a}}$ ed. Salvador: JusPODIVM, 2011. v. 1. 633 p.

DINAMARCO, Cândido Rangel. Instituições de Direito Processual Civil. $5^{\mathrm{a}}$ ed. São Paulo: Malheiros, 2005. v. 1. 735 p. 
. Execução Civil. $7^{\mathrm{a}}$ ed. São Paulo: Malheiros, 2000. 97 p.

DUGUIT, Léon. Fundamentos do Direito. São Paulo: Servanda, 2008. 80 p.

FERRAZ Jr., Tércio Sampaio. Introdução ao Estudo do Direito: Técnica, decisão, dominação. $6^{\mathrm{a}}$ ed. São Paulo: Atlas, 2012. 346 p.

FERRAZ Jr., Tércio Sampaio. Os dois corpos do rei: o jogo da legitimidade. In: ALQUÉRES, José Luiz; NEVES, José Roberto de Castro (Org.). Ele, Shakespeare, visto por nós, os advogados. Rio de Janeiro: Janeiro, 2017.p. 21 23.

FORGIONI, Paula A. Teoria geral dos contratos empresariais. $2^{\circ}$ ed. São Paulo: Revista dos Tribunais, 2010.271 p.

FRANCO, Vera Helena de Mello. Contratos: Direito civil e empresarial. $4^{\mathrm{a}} \mathrm{ed}$. São Paulo: Revista dos Tribunais, 2013. 446 p.

GAGLIANO, Pablo Stolze; PAMPLONA Filho, Rodolfo. Novo Curso de Direito Civil: obrigações. $18^{\mathrm{a}}$ ed. Rio de Janeiro: Saraiva, 2017. v. 2. 422 p.

GARCIA-ROZA, Luiz Alfredo. Palavra e Verdade: Na filosofia antiga e na psicanálise. $5^{\mathrm{a}}$ ed. Rio de Janeiro: Zahar, 2005. 104 p.

GERTNER, Robert; AYRES, Ian. Filling Gaps in Incomplete Contracts: An Economic Theory of Default Rules. In: POSNER, Richard A.; Parisi, Franceso. Economic Foundations of Private Law. Massachusetts: Edward Elgar, 2002. p. 476 - 519. 
GUERREIRO. José Alexandre Tavares. Equidade em Shakespeare. In: ALQUÉRES, José Luiz; NEVES, José Roberto de Castro (Org.). Ele, Shakespeare, visto por nós, os advogados. Rio de Janeiro: Janeiro, 2017. p. 145 $-151$.

GRAU, Eros Roberto. Ensaio e Discurso sobre a Interpretação/ Aplicação do Direito. $4^{\mathrm{a}}$ ed. São Paulo: Malheiros, 2006. 286 p.

. Por que tenho medo dos juízes: A interpretação/aplicação do direito e os princípios. $6^{\mathrm{a}}$ ed. São Paulo: Malheiros, 2013. 176 p.

GREENBLATT, Stephen. Como Shakespeare se tornou Shakespeare. Tradução de Donaldson M. Garschagen; Renata Guerra. São Paulo: Companhia das Letras, 2011.456 p.

GREENWOORD, Cynthia. The Complete guide to Shakespeare's plays. Nova Iorque: Alpha, 2008. 368 p.

GROSSI, Paolo. Mitologias jurídicas da modernidade. $2^{\mathrm{a}}$ ed. Trad. Arno Dal Ri Júnior. Florianópolis: Fundação Boiteux, 2007. 158 p.

HALLADAY, Frank Ernest. Shakespeare and his world. $5^{\mathrm{a}}$ ed. Londres: Thames \& Hudson, 1979. 147 p.

HEERS, Jacques. O ocidente nos séculos $X I V$ e $X V$ : aspectos econômicos e sociais. Tradução de Anne Arnichand da Silva. São Paulo: Pioneira, 1981. 357 p. 
HELIODORA, Bárbara. A Comédia dos Erros e O Mercador de Veneza. Rio de Janeiro: Nova Fronteira,1990. 254 p.

HELIODORA., Barbara. Os teatros no tempo de Shakespeare. In: LEÃO, Liana de Camargo; SANTOS, Marlene Soares dos (Org.). Shakespeare, sua época e sua obra. Curitiba: Beatrice, 2008. p. $65-80$.

HESPANHA. António Manuel. História das Instituições: Épocas medieval e moderna. Coimbra: Almedina, 1982. 569 p.

JHERING, Rudolf Von. A Luta pelo Direito. $17^{\mathrm{a}}$ ed. Tradução de João de Vasconselos. Rio de Janeiro: Revista Forense, 1999. 88 p.

KEETON, George Williams. Shakespeare and his legal problems. London: A \$ C. Black, 1930. 239 p.

LEÃO, Liana de Carmargo; SANTOS, Marlene Soares dos. Shakespeare, sua época e sua obra. Curitiba: Beatrice, 2008. 360 p.

LEMES, Selma Ferreira. Shakespeare e Veneza, o retrato do tempo. In: ALQUÉRES, José Luiz; NEVES, José Roberto de Castro (Org.). Ele, Shakespeare, visto por nós, os advogados. Rio de Janeiro: Janeiro, 2017. p. 119137.

LOPES, José Reinaldo de Lima. $O$ direito na história: Lições introdutórias. $4^{\text {a }}$ ed. São Paulo: Atlas, 2012. 480 p.

MARTINS, Fran. Contratos e obrigações comerciais. 14 ${ }^{\text {a }}$ ed. Rio de Janeiro: Forense, 1998. 542 p. 
MCGUIRE, Laurie; SMITH, Emma. 30 Great Myths About Shakespeare. Chichester: John Wiley \& Sons, 2013. 216 p.

MICELI, Paulo. História Moderna. São Paulo: Contexto, 2016. 158 p.

MORAES, Maria Celina Bodin de. Danos à Pessoa Humana: Uma Leitura Civil Constitucional dos Danos Morais. $2^{\mathrm{a}}$ ed. Rio de Janeiro: Processo, 2017. 358 p.

NALIN, Paulo. Função social do Contrato no futuro código civil brasileiro. In: TEPEDINO, Gustavo; FACHIN, Luiz Edson (Org.) Obrigações e Contratos. São Paulo: Revista dos Tribunais, 2011. v. 3. p. 841 - 853.

NEGREIROS, Teresa. Teoria do Contrato: Novos paradigmas. $2^{\mathrm{a}}$ ed. Rio de Janeiro: Renovar, 2006. 544 p.

NEVES, José Roberto de Castro. Direito das Obrigações. $3^{\mathrm{a}}$ ed. Rio de Janeiro: GZ, 2012. 414 p.

NEVES, José Roberto de Castro. Medida por Medida: O Direito em Shakespeare. $5^{\mathrm{a}}$ ed. Rio de Janeiro: Edições de Janeiro, 2016. 416 p.

PERELMAN, Chaïm, Ética e direito. Tradução de Maria Ermantina Galvão G. Pereira. São Paulo: Martins Fontes, 1996. 722 p.

PERLINGIERI, Pietro. Perfis do Direito Civil: Introdução ao direito civil constitucional. Tradução de Maria Cristina De Cicco. $3^{\mathrm{a}}$ ed. Rio de Janeiro: Renovar, 2002. 369 p. 
PEREIRA, Caio Mario da Silva. Instituições de Direito Civil: Introdução ao Direito Civil. 24a ed. Rio de Janeiro: Forense, 2011. v. 1. 594 p.

. Instituições de Direito Civil: Teoria Geral das Obrigações. 25ª ed. Rio de Janeiro: Forense, 2012. v. 2. 429 p.

. Instituições de Direito Civil. Contratos. $17^{\mathrm{a}}$ ed. Rio de Janeiro: Forense, 2013. v. 3. 570 p.

POSNER, Richard A. "Law and Literature: A Relation Reargued". Virginia Law Review. Virginia, n. 8, v. 72.p. 1351 - 1392, nov. 1986.

POSNER, Richard A. ; Parisi, Franceso. Economic Foundations of Private Law, Massachusetts: Edward Elgar, 2002. 669 p.

POSNER, Richard A.; FRIED, Charles. Shylock on Trial: The Appellate Briefs. Chicago: University of Chicago Press, 2013. 23 p.

RAWLS, John. Uma Teoria da Justiça. Tradução de Almiro Pisetta e Lenita M. R. Esteves. 2a ed. São Paulo: Martins Fontes, 2000. 701 p.

RAZ, Joseph. The morality of freedom. Oxford: Clarendon Press, 1986. 429 p.

ROPPO, Enzo. O Contrato. Tradução de Ana Coimbra e M. Januário C. Gomes. São Paulo: Almedina, 2009. 367 p.

SANTOS, Deborah Pereira dos; MENDES, Eduardo Heitor. Função, funcionalização e função social. In: SCHREIBER, Anderson; KONDER, Carlos Nelson. Direito Civil Constitucional. São Paulo: Atlas. 2016. p. 97 - 124. 
SARMENTO, Daniel. Direitos Fundamentais e Relações Privadas. $2^{\mathrm{a}}$ ed. Rio de Janeiro: Lumen Juris, 2010. 362 p.

SCHREIBER, Anderson; KONDER, Carlos Nelson. Direito Civil Constitucional. São Paulo: Atlas, 2016. 242 p.

SCHWARTZ, Alan. The Case for Specific Performance In: POSNER, Richard A.; PARISI Francesco, Economic Foundations of Private Law. Massachusetts: Edward Elgar, 2002. p. $385-519$.

SEARLE. John R. Mente, Linguagem e Sociedade: Filosofia no mundo real. Tradução de F. Rangel. Rio de Janeiro: Rocco, 2000. 160 p.

SHAKESPEARE, WILLIAM. The Merchant of Venice. Londres: Collector's Library, 2011. 153 p.

SHECAIRA, Fábio P.; STRUCHINER, Noel. Teoria da argumentação jurídica. Rio de Janeiro: ed. PUC-Rio: Contraponto, 2016. 184 p.

SMITH, Busato Cristine. A vida de William Shakespeare. In: LEÃO, Liana de Camargo; SANTOS, Marlene Soares dos Santos. Shakespeare, sua época e sua obra. Curitiba: Beatrice, 2008. p. 19 - 34.

STRECK, Lenio Luiz. Hermenêutica jurídica e(m) crise: Uma exploração hermenêutica da construção do direito. $10^{\mathrm{a}}$ ed. Porto Alegre: Livraria do Advogado, 2011. $420 \mathrm{p}$.

. Verdade e Consenso: Constituição, hermenêutica e teorias discursivas. $4^{\mathrm{a}}$ ed. Rio de Janeiro: Saraiva, 2011. 639 p. 
SOARES, Felipe Ramos Ribas; MATIELI, Louise Vago; DUARTE, Luciana da Mota Gomes de Souza. Unidade do ordenamento na pluralidade das fontes: uma crítica à teoria dos microssistemas. In: SCHREIBER, Anderson; KONDER, Carlos Nelson. Direito Civil Constitucional. São Paulo: Atlas. 2016. p. 71 - 95.

TEPEDINO, Gustavo; BARBOSA, Heloísa Helena; MORAES, Maria Celina Bodin de. Código Civil Interpretado: Conforme a Constituição da República. $2^{\mathrm{a}}$ ed. Rio de Janeiro: Renovar, 2011. v. 1. 773 p.

. Código Civil Interpretado: Conforme a Constituição da República. $2^{\mathrm{a}}$ ed. Rio de Janeiro: Renovar, 2012. v. 2. 912 p.

TEPEDINO, Gustavo; FACHIN, Luiz Edson (Org.). Obrigações e Contratos: Doutrinas essenciais. São Paulo: Revista dos Tribunais, 2011, v. 3. 1344 p.

VILLELA, João Baptista. Variações impopulares sobre a dignidade da pessoa humana. Superior Tribunal de Justiça: Doutrina. Edição comemorativa, 20 anos, Distrito Federal. p. 559-581, 2009.

WOLKMER, Antônio Carlos. História do direito no Brasil. $3^{\mathrm{a}}$ ed. Rio de Janeiro: Forense, 2002. 170 p.

\section{PRECEDENTES}

STF, HC 82.424, Rel. Min. Moreira Alves, Brasília, 03 mar. 2004.

STF, RE 363.889, Rel. Min. Dias Toffoli, Brasília, 02 jun. 2011. 